\title{
EFEITOS DE DIFERENTES SISTEMAS DE PREPARO ANTECIPADO DO SOLO E HERBICIDAS DE MANEJO NA INFESTAÇÃO DE PLANTAS DANINHAS E NA CULTURA DO ALGODOEIRO \\ (Gossypium hirsutum L. var. latifolium Hutch.)
}

\section{FERNANDO STORNIOLO ADEGAS}

Engenheiro Agrônomo

Orientador: Prof. Dr. RICARDO VICTORIA FILHO

Dissertação apresentada à Escola Superior de Agricultura "Luiz de Queiroz", da Universidade de São Paulo, para obtenção do Título de Mestre em Agronomia, Área de Concentração : Fitotecnia

\section{PIRACICABA}

Estado de São Paulo - Brasil

Novembro - 1994 
Ficha catalográfica preparada pela seção de Livros da Divisão de Biblioteca e Documentação - PCLQ/USP

\footnotetext{
Adegas, Fernando storniolo

A228e Efeitos de diferentes sistemas de preparo antecipado do solo e herbicidas de manejo na infestação de plantas daninhas e na cultura do algodoeiro (Gossypium hirsutum I. var. latifolium Hutch.). Piracicaba, 1994. 109p. ilus.

Diss. (Mestre) - ESALQ Bibliografia.
}

1. Algodão - Planta daninha 2. Herbicida em algodão Manejo 3. Solo - Preparo I. Escola superior de Agricultura Luiz de Queiroz, Piracicaba 


\section{EFEITOS DE DIFERENTES SISTEMAS DE PREPARO ANTECIPADO DO SOLO E HERBICIDAS DE MANEJO NA INFESTAÇÃO DE PLANTAS DANINHAS E NA CULTURA DO ALGODOEIRO (Gossypium hirsutum L. var. latifolium Hutch.)}

Aprovada em: 24.11.1994

Comissão julgadora:

Prof. Dr. Ricardo Victoria Filho

Prof. Dr. Pedro Jacob Christoffoleti

Dr. Luiz Henrique Carvalho
ESALQ/USP

ESALQ/USP

IAC

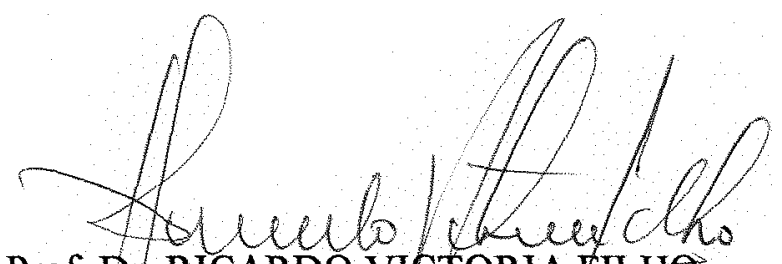

Prof. Dr. RICARDO VIGTORIA FHHO 


\section{Aos meus pais}

Sebastião e Alzira

Pelo esforço dedicado à minha formação

Minha homenagem

À minha esposa Soelma

E a minha filha Heloísa

Dedico 


\section{AGRADECIMENTOS}

Expresso meus sinceros agradecimentos a todos que contribuiram para a realização deste trabalho, e em especial, às seguintes instituições e pessoas:

- À Escola Superior de Agricultura "Luiz de Queiroz" e à Empresa Paranaense de Assistência Técnica e Extensão Rural, pela oportunidade de participação e realização do curso.

- Ao Conselho Nacional de Desenvolvimento Científico e Tecnológico (CNPq), pelo apoio financeiro através da bolsa de estudos.

- Ao Professor Dr. Ricardo Victoria Filho, pelo incentivo, apoio, amizade e orientação durante a realização do curso.

- Aos professores dos Departamentos de Horticultura e Agricultura da Escola Superior de Agricultura "Luiz de Queiroz", nas pessoas dos professores Keigo Minami e Jairo Teixeira Mendes Abraão.

- À todos os funcionários do Departamento de Horticultura da Escola Superior de Agricultura "Luiz de Queiroz", em especial a Sra. Helena Rodrigues Camargo, Sr. Luiz Ferrari e Sr. Aparecido Mendes. 
- Às secretárias do Departamento de Horticultura da Escola Superior de Agricultura "Luiz de Queiroz", Maria Célia Rodrigues, Elizabete Aparecida Sarkis e Maria Ivete Monteiro de Almeida.

- Ao Professor Pedro Jacob Christoffoleti pelo auxílio na redação do summary.

- Aos colegas de Departamento Clotilde P. Ferri, Diva Diniz, Francisco Passos, Júlio C.S M. Barros, Lúcia H.S.M de Castro, Paulo S.R Araújo, Rosiris B.A. Silveira, Sérgio B.M. Barros, Sérgio Obara, Silvana C.S. Bueno e demais colegas de outros departamentos, pela amizade e sadio convívio durante o curso.

- À professora Sonia Maria de Estefano Piedade pela orientação e auxilio na análise estatística.

- Aos meus irmãos Rossana, Valéria, Patrícia e Ricardo e demais familiares pelo estímulo e apoio.

- A todos que contribuíram de alguma forma, para que este trabalho pudesse ser realizado.

- A Deus, por iluminar e abençoar meu caminho. 


\section{SUMÁRIO}

Página

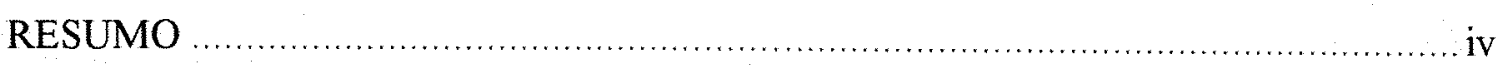

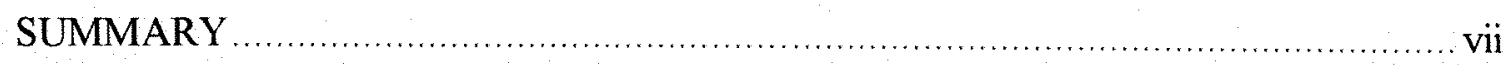

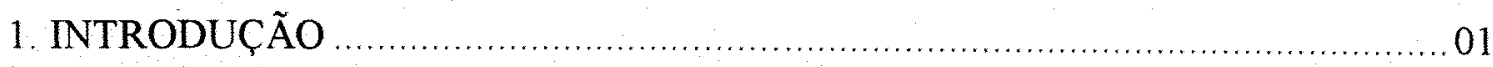

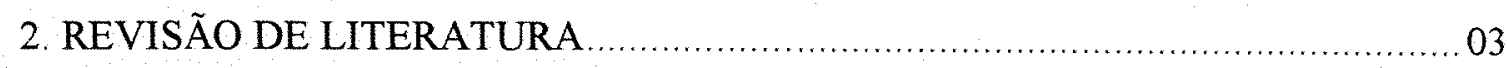

2.1. Interferência das plantas daninhas na cultura do

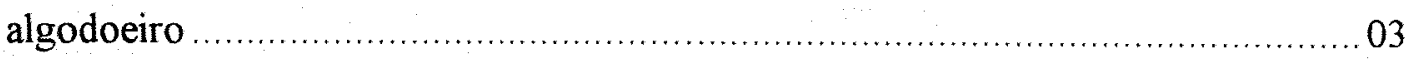

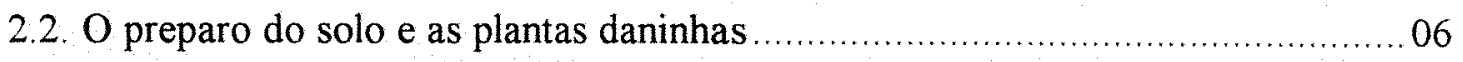

2.3. O preparo do solo e a cultura do algodoeiro ......................................... 11

2.4. Herbicidas de manejo ............................................................... 14

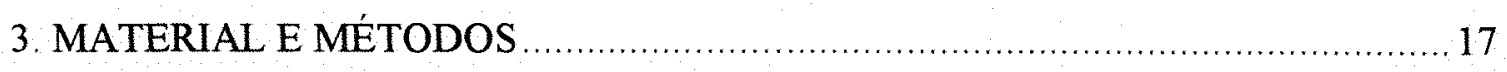

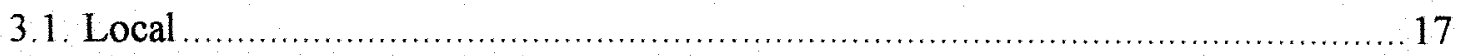

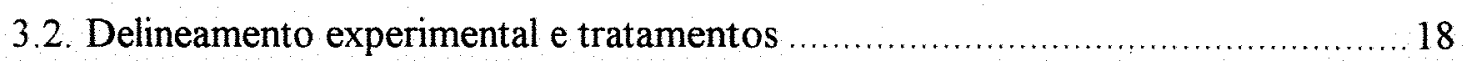

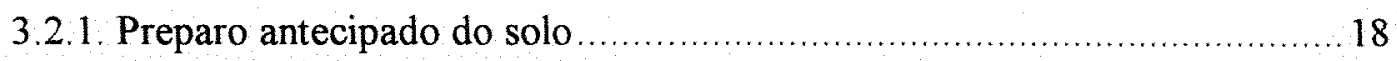

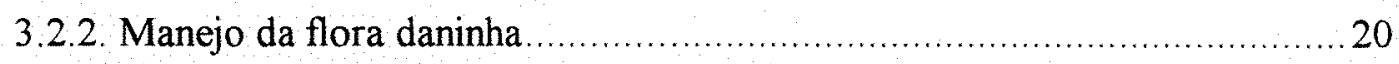

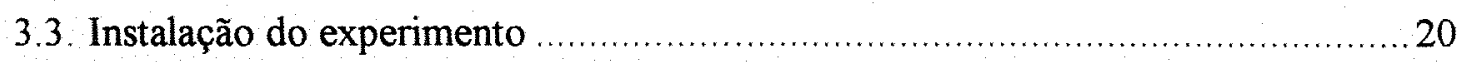

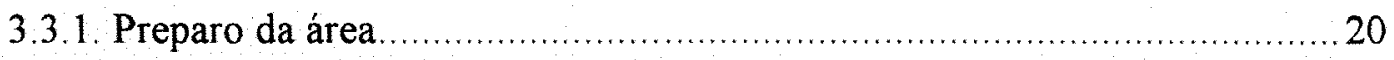

3.3.2. Aplicação dos herbicidas de manejo ....................................... 22

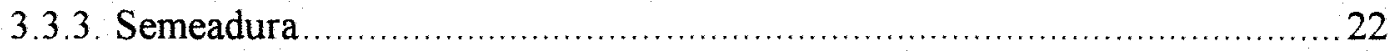

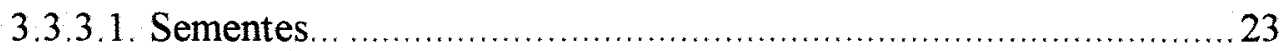

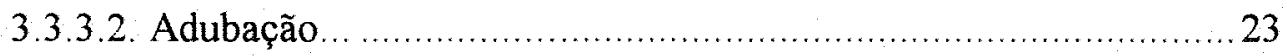

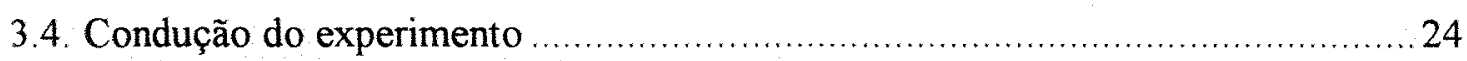

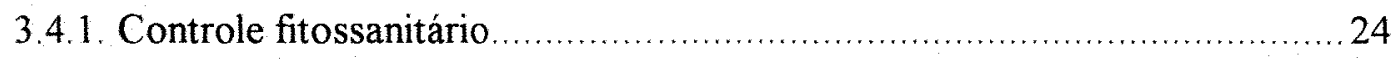

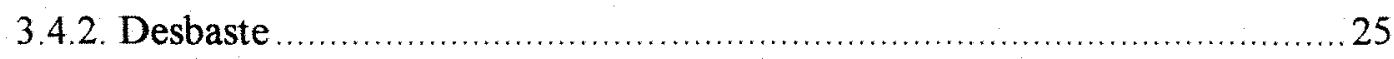

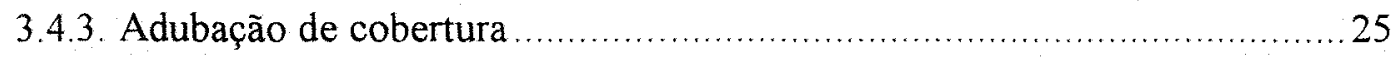


Página

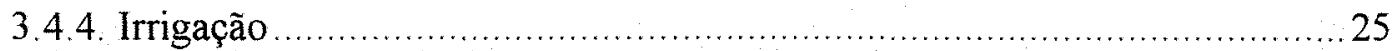

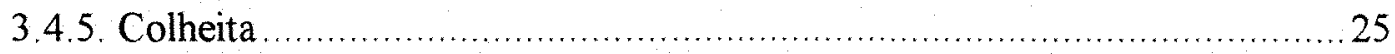

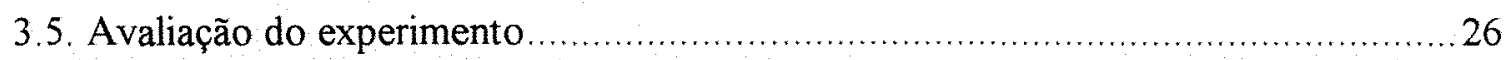

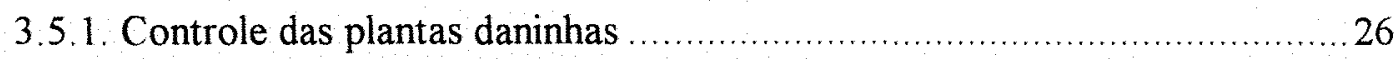

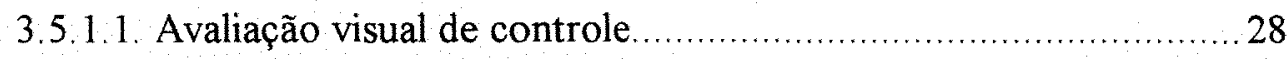

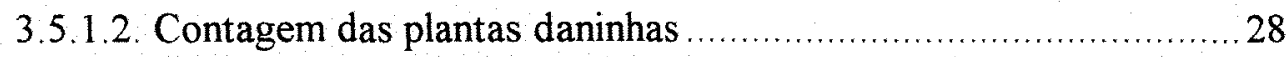

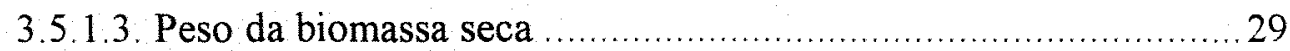

3.5.2. Comportamento da cultura do algodoeiro …..................................... 30

3.5.2.1. Características fitotécnicas …................................................. 30

3.5.2.1.1. Altura das Plantas ................................................30

3.5.2.1.2. Diâmetro do caule ………..................................... 30

3.5.2.1.3. Número de ramos produtivos ....................................30

3.5.2.1.4. Altura de inserção do primeiro ramo

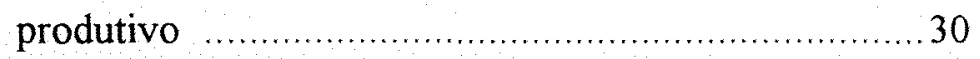

3.5.2.1.5. Ocorrência do primeiro capulho ………................... 31

3.5.2.1.6. Número de capulhos por planta ................................31

3.5.2.1.7. Peso médio de um capulho .......................................31

3.5.2.1.8. Peso de 100 sementes …........................................ 31

3.5.2.1.9. Porcentagem de fibras ............................................ 31

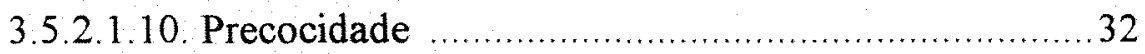

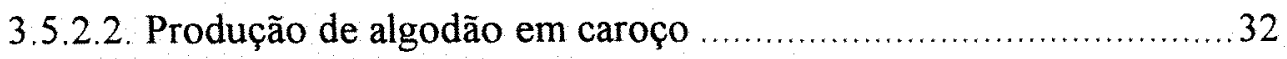

3.5.2.3. Características tecnológicas das fibras ...................................... 33

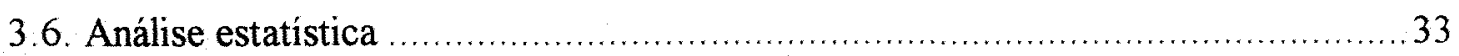

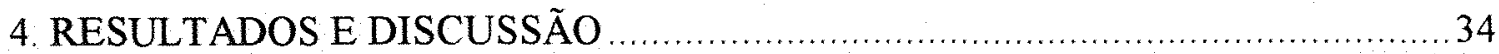

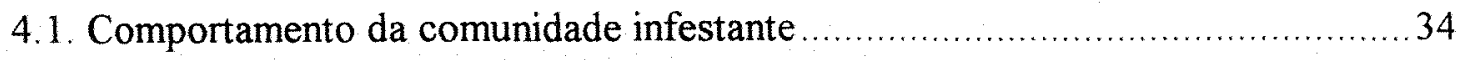

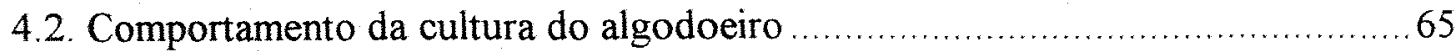


Página

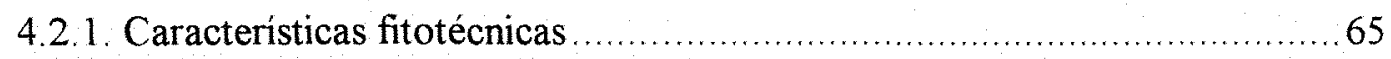

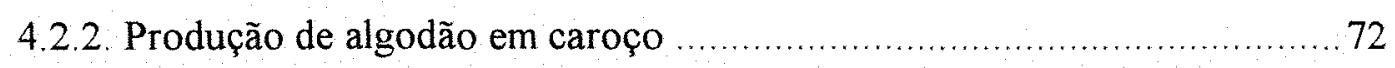

4.2.3. Características tecnológicas das fibras ........................................... 75

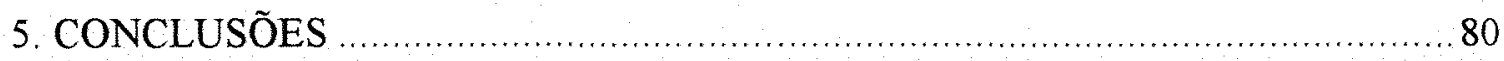

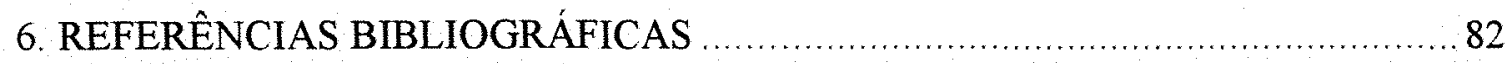

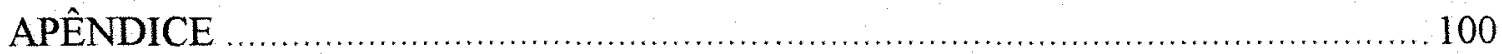




\title{
EFEITOS DE DIFERENTES SISTEMAS DE PREPARO \\ ANTECIPADO DO SOLO E HERBICIDAS DE PREPARO \\ NA INFESTAÇÃO dE PLANTAS DANINHAS E NA
}

iv

\author{
CULTURA DO ALGODOEIRO \\ (Gossypium hirsutum L. var. latifolium Hutch.)
}

AUTOR: FERNANDO STORNIOLO ADEGAS

ORIENTADOR: PROF. DR. RICARDO VICTORIA FILHO

\section{RESUMO}

Estudou-se a infestação por plantas daninhas e o comportamento da cultura do algodoeiro, variedade IAC-20, comparando-se três sistemas de preparo antecipado do solo, integrado à aplicação de três diferentes herbicidas de manejo. $\mathrm{O}$ experimento foi instalado em um Latossolo Vermelho-Amarelo Distrófico, no Município de Piracicaba-SP, Brasil.

Os três tratamentos de preparo do solo, instalados 45 dias antes do plantio da cultura, consistiram de: aração com grade aradora, à profundidade média 
de $13,2 \mathrm{~cm}$; incorporação de restos vegetais com grade aradora seguido de aração com arado de discos, à profundidade média de $26,9 \mathrm{~cm}$; aração com arado de discos, à profundidade média de $23,6 \mathrm{~cm}$. Os três herbicidas de manejo, aplicados sete dias antes do plantio da cultura, foram: paraquat $(0,6 \mathrm{~kg}$ i.a. $/ \mathrm{ha})$; paraquat + diuron $(0,6+$ $0,3 \mathrm{~kg}$ i.a./ha), glyphosate $(1,08 \mathrm{~kg}$ i.a./ha), com dois tratamentos testemunhas, com e sem controle das plantas daninhas

$O$ delineamento experimental foi o de 4 blocos ao acaso em parcelas subdivididas. Nas parcelas foram instalados os tratamentos de preparo antecipado, enquanto que as subparcelas receberam os tratamentos de manejo das plantas daninhas com herbicidas.

A avaliação do experimento com relação à incidência de plantas daninhas, foi feita através de contagens periódicas, peso da biomassa seca e avaliações visuais; sendo que, na cultura do algodão foi realizada a determinação de diversas características fitotécnicas e tecnológicas das fibras, e produção de algodão em caroço.

O preparo de solo mais profundo, obtido no conjunto grade aradora + arado, resultou em menor infestação de plantas daninhas do que o preparo mais superficial, obtido pela utilização isolada da grade aradora.

Glyphosate apresentou controle superior ao paraquat e paraquat + diuron para Digitaria horizontalis e Cyperus rotundus, sendo que para as demais plantas daninhas os resultados não mostraram diferenças significativas entre os herbicidas aplicados. A aplicação do herbicida de manejo isoladamente não foi 
suficiente para o controle eficiente das plantas daninhas durante todo o ciclo da cultura.

A mato-interferência causou alterações nas características fitotécnicas do algodoeiro, reduzindo sua altura, diâmetro do caule, número de ramos produtivos, número de capulhos por planta, peso de um capulho, peso de 100 sementes e sua precocidade e, aumentando a altura de inserção do primeiro ramo produtivo e o tempo de ocorrência do primeiro capulho. A porcentagem de fibras não foi alterada. A qualidade das fibras de algodão foi prejudicada pela mato-interferência, com depreciação no comprimento, finura, tenacidade, uniformidade e maturidade. Maiores produções de algodão em caroço foram obtidas nos tratamentos com menor infestação de plantas daninhas. 


\section{EFFECTS OF DIFFERENT ANTECIPATED TILLAGE \\ SYSTEMS AND MANEGEMENT HERBICIDES ON WEED \\ INFESTATION AND COTTON (Gossypium hirsutum}

L. var. Iatifolium Hutch.) CROP BEHAVIOR

vii

Author: FERNANDO STORNIOLO ADEGAS

Adviser: PROF. DR. RICARDO VICTORIA FILHO

\section{SUMMARY}

The weed infestation and the cotton crop behaviour comparing three systems of antecipated tillage, integrated to the application of three different management herbicide was studied. The experiment was installed in a Yellow-Red Distrophic Latosol soil in Piracicaba-SP, Brazil.

The three treatments of tillage, installed 45 days before sowing, consisted of ploughing with a disc plough, at an average depth of $23,6 \mathrm{~cm}$; ploughing with heavy-duty disc harrows, at an average depth of $13,2 \mathrm{~cm}$ and, incorporation of stubble with heavy-duty disc harrows followed by the ploughing with a disc plough, at an average depth of $26,9 \mathrm{~cm}$. The three management herbicide applied seven days before sowing were: paraquat $(0,6 \mathrm{~kg}$ a.i. $/ \mathrm{ha})$, paraquat + diuron $(0,6+0,3 \mathrm{~kg}$ a.i. $/ \mathrm{ha})$ 
and glyphosate $(1,08 \mathrm{~kg}$ a.i./ha), besides the weeded plot and weed free during all cotton growing season.

The experimental design was split-plot with 4 randomized blocks. The main plots consisted of the antecipated tillage treatments, whereas the subplots received the herbicide treatments for weed management.

The evaluation of the experiment was done by periodical weed counting, dry weight and visual evaluation of weeds and by the determination of several phytotechnical characteristics of the cotton, technological characteristics of the obtained fibers and seed cotton yield.

The deeper tillage, obtained by the set heavy-duty disc harrows + disc plough, resulted in a lower weed infestation than the shallower preparation with the use of heavy-duty disc alone.

Glyphosate showed better control of Digitaria horizontalis and Cyperus rotundus than paraquat and paraquat + diuron but for other weeds, the results did not show significant differences among the herbicides Herbicide management alone was not enough to control the weeds during the cotton crop growing season.

The weed competition altered the phytotechnical characteristics of the cotton, decreasing its height, stem diameter, number of produitive branches, number of bolls per plant, weight of a boll, weight of hundred seeds and its precocity; and increasing the height of the first produitive branch insertion and delaying the occurrence time of the first boll. The percentage of fibers was not altered. The quality of cotton fibers was damaged by the weed competition, with depreciation in the 
lenght, thinness, tenacity, uniformity and maturity. Higher cotton seed yield were obtained in the treatments with lower weed infestation. 


\section{INTRODUÇÃO}

Historicamente o preparo do solo sempre foi considerado uma importante etapa na exploração agrícola. No entanto, a evolução nessa área objetivou basicamente o aumento do rendimento dos equipamentos utilizados para tal fim, esde a confecção das primeiras ferramentas rústicas a milênios atrás, passando pelo arado de aiveca na Idade Média, até os moderníssimos maquinarios existentes hoje.

A crescente preocupação com as questões ecológicas aliada à necessidade de ajuste do balanço energético na produção agrícola, principalmente nas duas últimas décadas, tem possibilitado um redirecionamento no enfoque do estudo do preparo do solo, buscando obtenção de sistemas eficazes quanto ao rendimento operacional, mas principalmente, mais racionais em relação ao consumo de energia e a influência nas características fisicas, químicas, biológicas e de conservação dos solos.

A partir dessa visão, desenvolveram-se trabalhos no sentido de reduzir a mobilização dos solos e ao mesmo tempo realizar essas operações em épocas mais adequadas. É imprescindivel, contudo, a integração desses estudos com a análise de dois aspectos intimamente relacionados ao preparo do solo: a instalação e desenvolvimento das culturas e a infestação das plantas daninhas.

Esse detalhamento da pesquisa deve-se ao fato de cada cultura ter suas características peculiares, ganhando importância aquelas consideradas exigentes em 
preparo do solo e pouco competitivas em relação às plantas daninhas, como é o caso típico da cultura do algodoeiro (Gossypium hirsutum L.)

A produção mundial de algodão em pluma safra $92 / 93$ foi de 18.180.000 toneladas, onde o Brasil contribuiu com 414.000 toneladas ocupando a posição de $7^{\circ}$ país produtor. A macro região centro-sul foi responsável por $88 \%$ dessa produção, destacando-se os estados do Paraná com $41 \%$ e São Paulo com $32 \%$ (SUMMA AGRÍCOLA, 1993).

Nos Estados do Paraná e São Paulo, a implantação da cultura do algodoeiro caracteriza-se pelo pequeno intervalo recomendado para plantio, entre 20 de setembro a 20 de outubro (GRIDI-PAPP et al., 1992; YAMAOKA \& PIRES, 1993), acarretando uma concentração das operações de preparo do solo e semeadura num curto período de tempo. Isso torna a instalação da cultura muito sensível a imprevistos climáticos ou operacionais, que podem facilmente provocar o não cumprimento das épocas e prazos ideais para a execução dessas operações.

Nesse contexto, um sistema de produção baseado em um preparo antecipado do solo, integrado à aplicação de herbicidas de manejo em pré-plantio, seguido da semeadura direta da cultura, minimizariam esses riscos existentes para a implantação da cultura do algodoeiro.

Há, contudo, a necessidade de se estudar os efeitos dessas práticas sobre a comunidade de plantas daninhas e no comportamento da cultura do algodoeiro, que foi objetivo deste trabalho composto de três sistemas de preparo antecipado do solo, integrado à aplicação de três diferentes herbicidas de manejo. 


\section{REVISÃO DE LITERATURA}

\subsection{Interferência das Plantas Daninhas na Cultura do Algodoeiro}

A presença de plantas silvestres que emergem espontaneamente nos ecossistemas agrícolas acarreta uma série de fatores indesejáveis sobre as plantas cultivadas, daí a sua denominação de plantas daninhas. Nesse quadro, o termo interferência refere-se ao conjunto de ações que recebe uma determinada cultura em decorrência da comunidade de plantas daninhas num determinado local (PITELLI, 1985a)

A interferência entre a comunidade de plantas daninhas e o algodoeiro prejudica diretamente a produtividade da cultura pela competição exercida por nutrientes, água, luz e espaço (ABRAHÃO, 1985). Essa competição resulta na redução da altura da planta e diâmetro do caule, menor tamanho da maçã, diminuição do peso de capulho e semente, e queda na produção de fibras (SALOME, 1988) No Brasil, a diminuição de produtividade pode atingir altos níveis, como $94 \%$ (BLANCO \& OLIVEIRA, 1976), 90\% (LACA-BUENDIA et al., 1979), 89\% (MORAES et al., 1982), $88 \%$ (CIA et al., 1978) e 85\% (AZEVEDO et al., 1978). 
A colheita do algodoeiro também é prejudicada pela interferência das plantas daninhas, diminuindo o seu rendimento e aumentando os custos, seja pela aderência de partes vegetais na fibra do algodão, seja pela dificuldade de trânsito na lavoura (COLWICK et al, 1984).

Qualitativamente a fibra de algodão sofre depreciação com a interferência das plantas daninhas, pois existem problemas na classificação em tipo, devido a aderência de sementes, folhas e caules secos das plantas daninhas às fibras do algodão, como é o caso de Digitaria horizontalis. Também a resistência da fibra é comprometida pelo desgaste dos dentes das serras das máquinas beneficiadoras provocado pelas sementes de algumas plantas daninhas, como Cenchrus echinatus, aderidas a fibra (LACA-BUENDIA, 1990).

As plantas daninhas ainda são passíveis de serem hospedeiras de pragas, doenças e nematóides que atacam a cultura do algodão, sendo exemplo típico a mosca-branca (Bemisia tabaci), que é vetora do vírus transmissor do mosaico comum e se hospeda em plantas de Sida spp (SANTOS, 1993).

Os fatores que afetam o grau de interferência entre as plantas daninhas e uma cultura agrícola estão ligados à própria cultura (espécie, densidade, espaçamento e ciclo de cultivo), à comunidade infestante (espécie, densidade e distribuição) e à época e extensão do período de convivência, sofrendo alterações de acordo com as condições climáticas, edáficas e os tratos culturais (BLANCO, 1972).

Em relação a cultura, o algodoeiro possue baixa capacidade competitiva referente as plantas daninhas, sendo as principais causas o crescimento inicial lento e o largo espaçamento de plantio, que fazem com que a cultura leve cerca de 90 dias para cobrir totalmente a área plantada (ALMEIDA, 1981) 
Com relação as plantas daninhas, HOLM et al. (1977) relatam a existência de aproximadamente 100 espécies que aparecem na cultura do algodoeiro em todo o mundo. Nos Estados de São Paulo e Paraná, que denominaremos de nossas condições pois é a região objeto desse trabalho, as principais plantas daninhas que ocorrem nos algodoais segundo ABRAHÃO (1985); GRIDI-PAPP et al. (1992); KRANZ (1991) e LEITÃO FILHO et al (1972) são: - monocotiledôneas. Brachiaria plantaginea (Link) Hitch., Cenchrus echinatus L., Commelina sp., Cynodon dactylon (L.) Pers,, Cyperus rotundus L., Digitaria sp., Eleusine indica (L.) Gaertn., Eragrostis pilosa (L.) Beauv., Panicum maximum Jacq., Rhynchelitrum roseum (Nees) Stapf. et Hubb. e Sorghum halepense (L.) Pers - Dicotiledôneas: Acanthospermum hispidum DC. (Loefl) O. Kuntze, Alternanthera ficoidea (L) R. Bt., Amaranthus sp, Bidens pilosa L., Blainvillea rhomboidea Cass, Emilia sonchifolia DC, Euphorbia heterophyla L., Galinsoga parviflora L., Indigofera hirsuta L., Ipomoea spp., Portulaca oleracea L,, Richardia brasiliensis Gomez e Sida spp.

Sob o aspecto do período de convivência, Tharp (1960) destaca que na fase inicial de instalação da cultura, que vai da germinação até a formação da primeira folha verdadeira, a planta não depende da intensidade luminosa devido as reservas de suprimentos armazenados nos seus cotilédones. Essa fase que varia de acordo com a variedade e as condições ambientais não é de grande importância em relação a competição com plantas daninhas (BENEDICT, 1984)

Para as nossas condições, a primeira folha verdadeira do algodoeiro é formada entre 8-10 dias após a emergência (MARUR, 1993). A partir daí, uma nova folha será formada, em média, a cada 3 dias, com o aparecimento dos primeiros 
botões florais ao redor dos 40 dias e sendo o máximo florescimento de importância para a produção alcançado aproximadamente aos 85 dias (GRIDI-PAPP et al, 1992)

Este período, segundo WADDLE (1984), é o mais importante na formação do potencial produtivo da cultura, razão pela qual deve-se evitar ao máximo qualquer intempérie durante a sua vigência.

Nos trabalhos de pesquisa sobre o periodo de convivência do algodoeiro com as plantas daninhas para as nossas condições, observa-se pequenas variações nos resultados obtidos. Para BLANCO \& OLIVEIRA (1976) o período crítico de competição acontece nos primeiros 35 dias após a emergência da cultura; sendo que, na competição exclusiva com Cyperus rotundus L. BLANCO et al (1991) concluem que esse período aumenta para os primeiros 42 dias após a emergência; CIA et al (1978) destacam o intervalo entre 20-40 dias após a emergência como o período crítico de competição e IAPAR (1978) ressalta como período crítico entre 20-50 dias após a emergência da cultura.

\subsection{O preparo do solo e as plantas daninhas}

Um dos objetivos principais do preparo do solo é enterrar as plantas daninhas e as suas sementes para reduzir sua emergência. Desse modo é quase obrigatório avaliar a população de plantas daninhas quando se trabalha com diferentes sistemas de preparo do solo, atentando-se para o seu número e separando-as por espécies ou grupo taxonômico (CASTRO, 1990). 
A modificação de fatores edáficos como o teor de água, temperatura e tamanho dos agregados, decorrentes do tipo de preparo de solo utilizado, afeta diretamente $o$ grau de infestação das plantas daninhas. Além disso, após a maturação dessas plantas, as sementes que caem ao solo poderão situar-se em diferentes profundidades do perfil, devido à mobilização causada pelas máquinas e implementos de preparo do solo (ANTUNIASSI, 1991).

CASTRO (1989) afirma que a eficiência do preparo do solo no controle das plantas daninhas depende da profundidade de incorporação das suas sementes. Assim o revolvimento como o realizado pelo arado de aiveca ou de discos permite menor emergência das plantas daninhas do que um preparo mais raso, como é o caso da grade pesada.

A eficiência no controle das plantas daninhas por incorporação profunda dos seus propágulos reprodutivos é reafirmada pela maioria das pesquisas como a de TANG \& WANG (1986) que usando uma escala crescente de 1 a 5 , encontraram infestações dos níveis 4-5 para o preparo superficial do solo contra nível 3 para o preparo profundo, e SEGUY et al (1984) que em solos de baixa fertilidade e alta incidência de plantas daninhas, concluíram que o preparo superficial coloca as sementes das invasoras perto da superficie do solo em condições ideais de germinação, o que não ocorre num preparo profundo.

No entanto, alguns autores como IKE (1986) e MONTEMAYOR (1992) não encontraram diferença no controle das plantas daninhas comparando o preparo superficial do solo com o profundo.

PITELLI (1985b) pondera que essa prática de enterrio das sementes no preparo do solo tem diminuido a sua eficiência, pois provocou uma rápida 
evolução na adaptação das plantas daninhas a esse distúrbio, através de inúmeros e complexos mecanismos de dormência de seus propágulos, resistência aos decompositores do solo, descontinuidade na germinação e emergência, e capacidade de germinar e emergir de camadas mais profundas do solo. A mobilização constante do solo, provoca também certa uniformidade das sementes no perfil da camada arável.

Com a tendência da diminuição das operações de mobilização do solo visando melhorar sua conservação, sistemas de preparo do solo como o cultivo mínimo, preparo reduzido e o plantio direto tem sido cada vez mais estudados, concomitantemente avalia-se também seus efeitos na flora daninha.

Tendo sempre como referencial o preparo convencional do solo (aração e gradagem), o cultivo mínimo ou o preparo reduzido apresentam, na maioria dos trabalhos de pesquisa, um pior resultado no controle das plantas daninhas, como mostram KURTS \& HURST (1984) que após 3 anos de cultivo de algodão chegaram a infestações no preparo convencional de 83 e $20 \%$, no $1^{\circ}$ e $3^{\circ}$ anos respectivamente, contra 91 e $46 \%$ no cultivo mínimo

TOUCHTON \& REEVES (1988) utilizando cultivo mínimo com subsolador e escarificador, obtiveram melhoria nas características fisicas do solo e maior aproveitamento dos fertilizantes, no entanto, o controle das plantas daninhas foi inferior ao preparo convencional.

Trabalhando com a cultura do açafrão na primavera, PAREJA et al. (1985) encontraram $85,0 \%$ das sementes de plantas daninhas nos primeiros $5,0 \mathrm{~cm}$ de solo em um sistema de preparo reduzido, sendo que no preparo convencional apenas $28,0 \%$ das sementes encontravam-se nessa profundidade. 
KLUTHCOUSKI et al (1987) realizando estudos por seis anos em solo de cerrado com a monocultura do arroz, obtiveram médias de $602,0 \mathrm{~g} / \mathrm{m}^{2}$ de biomassa seca de infestantes com preparo superficial contínuo, e $194,0 \mathrm{~g} / \mathrm{m}^{2}$ numa aração profunda contínua

Um baixo nível de infestação tende a diminuir as diferenças de controle entre o preparo convencional e o reduzido. Todavia com alto nível de infestação o preparo reduzido mostra-se claramente inferior (IKE, 1989).

Períodos de seca também tendem a minimizar as diferenças entre o preparo convencional e o reduzido. Todavia no caso de normalidade de chuvas o preparo convencional supera o reduzido no controle das plantas daninhas (ALMEIDA et al., 1982).

Com relação ao plantio direto, a ação conjunta do não revolvimento do solo, da cobertura morta e do uso adequado de herbicidas, provoca uma tendência de se desenvolver menor população de infestantes do que no preparo convencional (ALMEIDA, 1991).

FANCELLI \& FAVARIN (1989) relatam redução de $46,6 \%$ no número de plantas daninhas em cultura de milho no plantio direto comparado ao sistema convencional, após 2 anos de avaliação em Piracicaba. No Paraná, VEDOATO \& WILLES (1976) observaram presença significativamente menor de plantas daninhas em soja após trigo no plantio direto do que no cultivo mínimo

GONG \& LI (1993) após sete anos comparando o plantio direto e o convencional, concluíram que no plantio direto o número de sementes na camada de $10-20 \mathrm{~cm}$ do perfil do solo diminuiu $80,3 \%$, com taxa de germinação de $0,6 \%$, contra $24,1 \%$ do preparo convencional. 
ALMEIDA et al (1983) encontraram aumentos de 213,0\% no número de plantas daninhas no preparo reduzido e de $187,0 \%$ no preparo convencional, quando comparadas ao não preparo. Também a constituição específica foi influenciada pelo sistema de preparo Com a não movimentação, as gramíneas predominantes na área, capim-marmelada, capim-colchão e capim-carrapicho, mantinham uma densidade de população equilibrada, que foi alterada com a movimentação do solo, predominando o capim-marmelada.

A não movimentação do solo determina ainda a tendência do aumento das espécies infestantes perenes, como constatou CUSSANS (1975) em campos na Inglaterra e SOANE \& RODGER (1974) na Escócia. ALMEIDA (1981) no Paraná também verificou esse aumento das plantas daninhas perenes em plantio direto, concluindo que esse fato deve-se à pouca eficácia dos herbicidas utilizados no seu controle.

Em áreas onde existem espécies infestantes de dificil controle químico, especialmente quando essas apresentam-se desenvolvidas, o plantio direto geralmente apresenta resultados inferiores de controle do que o preparo convencional, como mostram BROWN \& WHITWELL (1985a) no Alabama trabalhando com Trifolium incarnatum e Vicia villosa e BROWN \& WHITWELL (1988) avaliando a influência dos sistemas de preparo do solo sobre a infestação de Conyza canadensis na cultura do algodoeiro. 


\subsection{O preparo do solo e a cultura do algodoeiro}

O algodoeiro é uma cultura muito exigente em relação ao preparo do solo. Um preparo eficiente deve objetivar o manejo correto dos restos vegetais, controle das plantas daninhas, melhoria da aeração do solo, incorporação e melhor aproveitamento de fertilizantes e corretivos, melhoria no controle da temperatura do solo, maior aproveitamento de água, bom contato das sementes com 0 solo proporcionando melhor germinação, maior eficácia no controle de pragas e doenças e controle da erosão (YAMAOKA, 1991).

Os métodos de preparo do solo variam, principalmente em função da vegetação anterior, do tipo e condições do solo, da declividade do terreno, das características climáticas da região e dos recursos de trabalho disponíveis na propriedade (GRIDI-PAPP et al, 1992).

PIMENTEL (1980) relata que para a cultura do algodoeiro no estado da Paraíba, prevalece a utilização do cultivador a tração animal seguido do preparo convencional com aração e gradagem tratorizada.

Para as nossas condições o preparo convencional tem adoção quase absoluta No Estado de São Paulo, CARVALHO (1990) relata a existência basicamente de dois sistemas do preparo convencional do solo para a cultura do algodoeiro: 1 -grade aradora + niveladora (1 ou 2) + grade incorporadora de herbicida, 2 - arado + grade niveladora $(1$ ou 2$)+$ grade incorporadora de herbicida, em ambos os casos pode-se usar o subsolador se necessário. No Estado do Paraná, YAMAOKA \& PIRES (1993) citam que o preparo convencional é feito com uma 
gradagem logo após a destruição da soqueira, posteriormente é realizada uma aração seguida de gradagem, com a complementação do preparo sendo feito com nova gradagem antes do plantio.

YAMAOKA (1991) afirma que os sistemas de preparo convencional de solo utilizados para a cultura do algodão, acarretam grande concentração de operações mecânicas num curto período de tempo e expõe as áreas a alto risco de erosão. CARNEIRO (1989) relata que as perdas por erosão nos algodoais são consideradas altas, podendo chegar a 24,8 ton solo/ha/ano.

Os estudos de métodos alternativos de preparo do solo para a cultura do algodão, visando acabar com os problemas trazidos pelo preparo convencional, vem sendo realizados com alguns resultados positivos, como os obtidos por YOO et al. (1988), que obtiveram menores índices de perdas por erosão e maiores produtividades no preparo reduzido com escarificador e no plantio direto do que no preparo convencional.

BEZERRA et al (1980) relatam o aumento da produção de algodão no preparo de solo em camalhões de $1,0 \mathrm{~m}$ e no plantio direto, bem como maior peso de capulho e maior altura das plantas do algodoeiro.

TOUCHTON \& REEVES (1988) afirmam que a utilização do subsolador ou escarificador proporcionam maior altura dos algodoeiros, maior peso do capulho, e maior produção final do que o preparo convencional do solo.

A substituição dos implementos de discos pela aiveca no preparo de solo para a cultura do algodoeiro foi testada por MEDEIROS \& SANTOS (1990), sendo o rendimento obtido com o arado de aiveca maior do que com o arado de 
discos e os preparos com grades. A utilização do arado de aiveca, no entanto, só se mostra viável em solos com teor de argila até 30\% (SILVEIRA, 1989)

Outra alternativa para a cultura do algodoeiro seria a realização do preparo antecipado do solo, como sugere PARRY (1982) para regiões tropicais, onde se realiza primeiramente a destruição dos restos vegetais invernais com grade leve ou roçadeira, com posterior enterrio profundo com arado ou subsolador. Em áreas muito infestadas de plantas daninhas o intervalo entre essas fases de preparo deve ser maior visando proporcionar máxima germinação dessas infestantes, para melhor controle quando do preparo profundo.

F.A.O (1987) também sugere a realização do preparo antecipado do solo, com o que denomina de preparo da cama, substituindo-se em alguns casos a última ação mecânica antes da semeadura, pela aplicação de herbicidas no manejo da comunidade daninha reinfestante da área.

A semeadura direta do algodoeiro ainda é incipiente em nossas condições, sendo os principais entraves para a sua implantação a disponibilidade de máquinas e equipamentos apropriados, instalação do sistema de conservação do solo, tipo de deslintamento das sementes e o controle das plantas daninhas, que é a principal delas (YAMAOKA, 1991).

Trabalhando com semeadura direta das culturas de sorgo, algodão e trigo, BROWN et al. (1987) concluiram que o algodoeiro foi o mais problemático em relação a competição com as plantas daninhas. Resultados semelhantes foram obtidos por JOHNSON (1985) pesquisando a semeadura direta das culturas de milho, soja e algodão. 
ALMEIDA \& RODRIGUES (1985) constataram a dificuldade de controlar as plantas daninhas em semeadura direta do algodoeiro, que em ensaio de três anos obtiveram média de infestação de $129 \mathrm{pl} / \mathrm{m}^{2}$ contra apenas $40 \mathrm{pl} / \mathrm{m}^{2}$ no plantio convencional.

YAMAOKA \& PIRES (1993) afirmam que a dificuldade de controlar as plantas daninhas na semeadura direta no algodoeiro, reside no fato da demora de até 80 dias para a cultura cobrir o terreno, período em que apenas os herbicidas de manejo não controlam as infestantes na sua totalidade. O problema se acentua por não se dispor de herbicidas de aplicação em pós-emergência seletivos especificos para a cultura.

Em casos onde haja um eficaz controle das plantas daninhas, a semeadura direta do algodoeiro pode oferecer produções maiores em até $110 \mathrm{~kg} / \mathrm{ha}$ de algodão em caroço do que no plantio convencional (HARMAN et al, 1989); bem como reduzir o custo de produção em US $\$ 3,46 / \mathrm{ha}$, com um retorno de capital de US\$ $90,12 / \mathrm{ha}$ para um aumento de produtividade de $61,0 \mathrm{~kg} / \mathrm{ha}$ de pluma.(DERTING, 1991).

\subsection{Herbicidas de manejo}

No sistema de semeadura direta, entende-se por operação de manejo a destruição da cobertura florística infestante por ocasião do plantio de determinada cultura, utilizando-se para tal, herbicidas de aplicação em pós-emergência (ALMEIDA, 1981). 
No Brasil, os herbicidas que estão registrados para serem utilizados na operação de manejo são: 2,4-D, diquat, glyphosate, MSMA, paraquat e glufosinate e as seguintes misturas formuladas diuron + MSMA, diuron + paraquat e 2,4-D + glyphosate (ANDREI, 1993; LORENZI, 1994).

Dentre os herbicidas de manejo, o paraquat e o glyphosate são os mais utilizados, sendo por conseguinte passíveis de muitos estudos no sentido de avaliar sua eficácia nessa operação (VOLL, 1987).

De maneira geral o paraquat é considerado um excelente graminicida, com ação também sobre largo espectro de latifoliadas, com maior eficácia no entanto, sobre espécies anuais e em estádio inicial de desenvolvimento (MOSELEY \& HAGOOD, 1990; WHITE, 1990; WIEPKE, 1990; BRUFF \& SHAW, 1992). A adição do diuron ao paraquat provoca efeito sinérgico, pois retarda a ação letal ao paraquat sobre os tecidos do floema, permitindo que se transloque a maiores distâncias, atuando portanto melhor em plantas em estádios mais adiantados de crescimento (ALMEIDA, 1991).

O glyphosate tem espectro mais amplo de espécies suscetiveis, com maior eficácia do que o paraquat sobre plantas perenes e em estádios mais avançados de crescimento (NIETO et al, 1989; VIOLOC et al, 1989; BRUCE \& KELLS, 1990; HIGGINS et al., 1991). A adição do 2,4-D ao glyphosate resulta em mistura com maior ação latifoliadicida, sem perder a ação graminicida do glyphosate (KOCH et al., 1989).

ALMEIDA (1991) relata que se pode encontrar três situações na operação de manejo: a) infestação pouco desenvolvida de plantas daninhas de folhas largas, recomenda o uso de 2,4-D ou diquat; b) infestação pouco desenvolvida de 
folhas largas e gramíneas, recomenda $o$ uso de paraquat, paraquat + diuron, glyphosate ou glyphosate $+2,4-D ;$ c) infestação desenvolvida de folhas largas e gramíneas, recomenda o uso de glyphosate, glyphosate + 2,4-D ou duas aplicações sequenciais de paraquat + diuron

Para a cultura do algodoeiro, YAMAOKA \& PIRES (1993) recomendam o glyphosate, paraquat e 2,4-D para serem utilizados no manejo, afirmando que apenas essa operação não é suficiente para controlar as plantas daninhas durante todo o ciclo da cultura. Isto é confirmado por ALMEIDA et al. (1986) que testaram o controle das infestantes apenas com a cobertura morta, só com herbicidas de manejo, herbicidas de manejo +2 capinas, e herbicidas de manejo + préemergentes, sendo que o único tratamento plenamente eficaz foi o que constou de capinas.

A falta de um herbicida latifoliadicida de aplicação em pré-emergência eficaz e seletivo para a cultura do algodoeiro que pudesse ser adicionado ou complementar a operação de manejo, é um dos entraves para a semeadura direta dessa cultura Em outros países produtores de algodão, o uso de fluometuron, herbicida pré-emergente, tem-se mostrado eficaz, como relata HURTS (1989) em trabalhos no Mississippi, EUA. 


\section{MATERIAL E MÉTODOS}

\subsection{Local}

O experimento foi realizado na área experimental do Departamento de Horticultura da Escola Superior de Agricultura "Luiz de Queiroz", Universidade de São Paulo, município de Piracicaba(SP), com latitude de $22^{\circ} 42^{\prime} 30^{\prime \prime} \mathrm{S}$ e longitude de $40^{\circ} 38^{\prime} 00^{\prime \prime} \mathrm{W}$

De acordo com a classificação de Köpen, o clima da região é do tipo CWA: mesotérmico úmido, subtropical com inverno seco. Os dados climatológicos de precipitação pluvial, umidade relativa, insolação e temperaturas mínimas, médias e máximas relativos ao período de condução do experimento, encontram-se descritos nas tabelas de 21 a 28 constantes no apêndice.

O solo da área foi classificado, segundo CAMARGO et al. (1987), como Latossolo Vermelho-Amarelo distrófico de textura arenosa, possuindo declividade média de $4 \%$ 


\subsection{Delineamento experimental e tratamentos}

O delineamento experimental utilizado foi o de 4 blocos ao acaso, no esquema fatorial $3 \times 5$ em parcelas subdivididas, num total de 15 tratamentos. Os tratamentos, esquematizados na Tabela 1 , foram compostos da interação de 3 parcelas de sistemas de preparo antecipado do solo com 5 sub-parcelas de manejo da flora daninha Cada sub-parcela foi composta de 5 linhas de algodoeiro espaçadas de $0,8 \mathrm{~m}$ e com $8,0 \mathrm{~m}$ de comprimento, num total de $32,0 \mathrm{~m}^{2}$. A área útil foi delimitada pelas três linhas centrais da cultura, com bordadura de $1,0 \mathrm{~m}$ nas extremidades, perfazendo um total de $14,4 \mathrm{~m}^{2}$.

\subsubsection{Preparo antecipado do solo}

As parcelas foram compostas de três sistemas de preparo primário do solo : aração com grade aradora, composta de 24 discos de 26 ", pré-incorporação dos restos vegetais com grade aradora composta de 24 discos de $26^{\prime \prime}$ e posterior aração com arado de discos composto de 4 discos de $28^{\prime \prime}$; aração com arado de discos composto de 4 discos de $28^{\prime \prime}$.

O preparo secundário para todos os sistemas, foi realizado numa única operação com grade destorroadora, composta de 48 discos de 18". 
TABELA 1 - Esquema dos tratamentos componentes do experimento de interação do preparo antecipado do solo, e manejo da flora daninha na cultura do algodoeiro em semeadura direta.

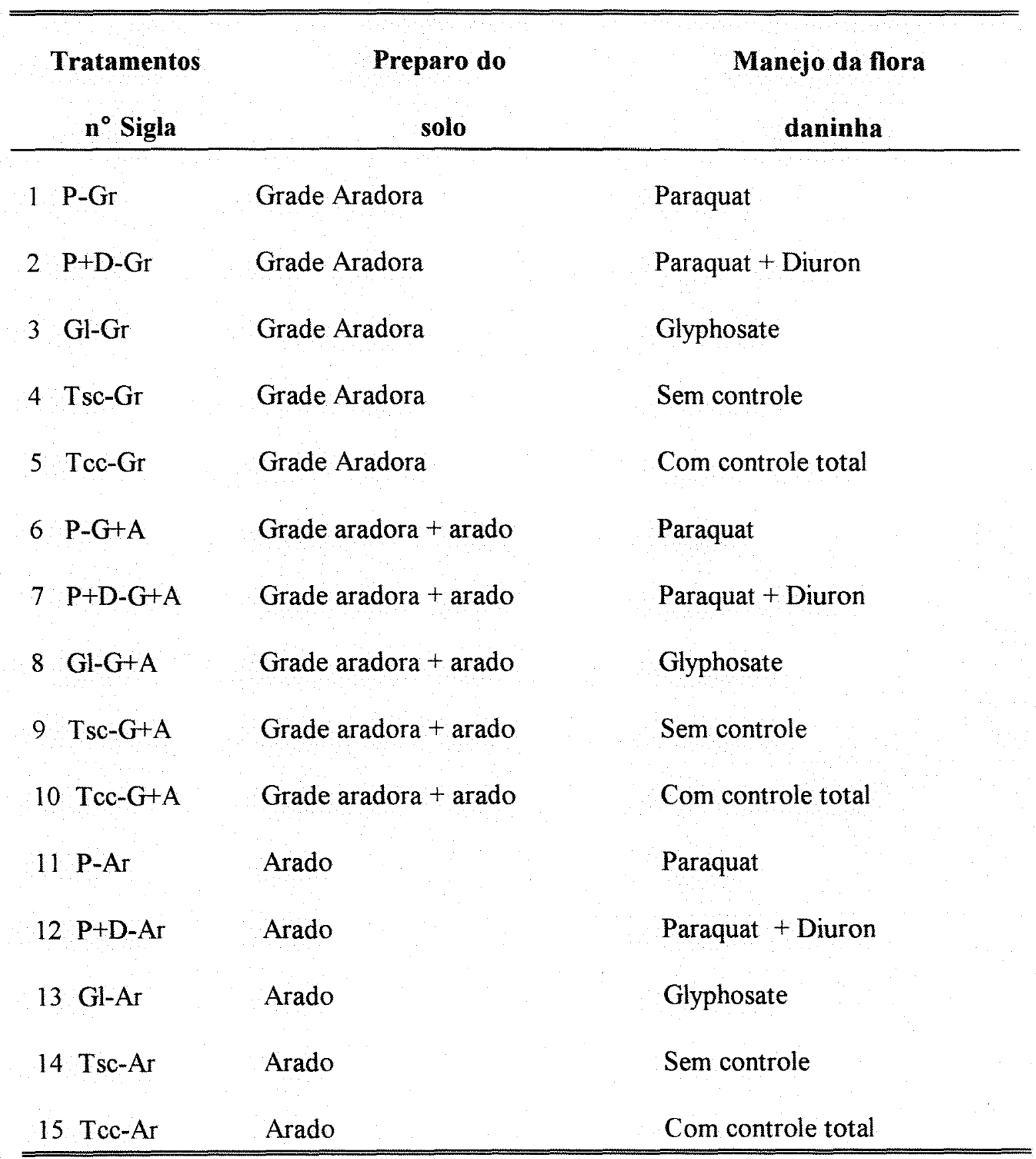




\subsubsection{Manejo da flora daninha}

As sub-parcelas foram compostas da aplicação única de três herbicidas de manejo: paraquat, na dose de $0,6 \mathrm{~kg}$ i.a. $/ \mathrm{ha}$; paraquat + diuron, na dose de $0,6 \mathrm{~kg}$ i.a. $/$ ha $+0,3 \mathrm{~kg}$ i.a. $/$ ha respectivamente, glyphosate, na dose de $1,08 \mathrm{~kg}$ i.a./ha e duas testemunhas: sem controle das plantas daninhas, com controle das plantas daninhas durante todo o ciclo da cultura, através da aplicação de glyphosate na dose de 1,08 kg.i.a/ha na operação de manejo, e capinas manuais a cada 14 dias após essa operação.

Os herbicidas utilizados no experimento, com seus nomes comuns, químicos e comerciais, bem como as formulações e os fabricantes estão apresentados na Tabela 2.

\subsection{Instalação do experimento}

\subsubsection{Preparo da área}

Os sistemas de preparo do solo foram implantados em faixa contínua dentro de cada bloco, com distância de $2,0 \mathrm{~m}$ entre os tratamentos e $8,0 \mathrm{~m}$ entre os blocos.

No dia $17 / 09 / 93$ realizaram-se os preparos primários, sendo amostrados com o auxílio de uma trena, 48 pontos por tratamento, visando medir a profundidade média de trabalho decada sistema, obtendo-se $23,6 \mathrm{~cm}$ para aração com arado; $13,2 \mathrm{~cm}$ para aração com grade, $26,9 \mathrm{~cm}$ para incorporação com grade seguido de aração com arado de discos. 
TABELA 2 - Nomes comum, químico, comercial, formulação, fabricante e classe toxicológica dos herbicidas usados no experimento.

\begin{tabular}{|c|c|c|c|c|c|}
\hline Nome comum & Nome químico & Nome comercial & Formulação & Fabricante & $\begin{array}{l}\text { Classe } \\
\text { toxicológica }\end{array}$ \\
\hline Paraquat & $\begin{array}{l}1,1 \text {-dimetil, 4,4-bipiridilio ion } \\
\text { dicloreto }\end{array}$ & Gramoxone 200 & $\mathrm{SA}^{*} 200 \mathrm{~g} / \mathrm{l}$ & ICI & I \\
\hline \multirow[t]{2}{*}{ Paraquat + Diuron } & $\begin{array}{l}1,1^{\prime} \text {-dimetil, 4,4-bipiridílio ion } \\
\text { dicloreto } 3-3,4 \text { dicloro-fenil, }\end{array}$ & Gramocil & $\begin{array}{l}\mathrm{SC}^{* * 200 \mathrm{~g} / 1} \\
+\end{array}$ & ICI & I \\
\hline & 1,1 dimetil uréia & & $100 \mathrm{~g} / 1$ & & \\
\hline Glyphosa-te & $\begin{array}{l}\text { Sal de isopropilamina de } \\
\mathrm{N}(\text { fosfometil glicina) }\end{array}$ & Roundup & SA $360 / \mathrm{g} / 1^{* * *}$ & Monsanto & IN \\
\hline
\end{tabular}

* $\quad \mathrm{SA}=$ Solução aquosa

** $\mathrm{SC}=$ Solução concentrada

*** Expresso em equivalente ácido 
A complementação do preparo do solo com o uso da grade destorroadora foi feito numa única operação dia 20/09, com profundidade média de trabalho de $7,1 \mathrm{~cm}$.

\subsubsection{Aplicação dos herbicidas de manejo}

A instalação dos tratamentos de herbicidas de manejo ocorreu no dia $29 / 10$, com a utilização de pulverizador costal à pressão constante de $2,1 \mathrm{~kg} / \mathrm{cm}^{2}$ $\left(\mathrm{CO}_{2}\right)$, equipado com barra de pulverização de $1,5 \mathrm{~m}$ contendo 4 bicos "Teejet" 80.03 em leque, distanciados entre si $50,0 \mathrm{~cm}$, obtendo altura de pulverização de $50,0 \mathrm{~cm}$, com calda de aplicação equivalente a 300,01/ha.

Para os tratamentos de paraquat e paraquat + diuron, adicionou-se $0,07 \% \mathrm{v} / \mathrm{v}$ do espalhante adesivo Agral (nonil fenoxi poli etanol - $200 \mathrm{~g} / \mathrm{l}$ ).

Durante a aplicação foram determinadas a temperatura do solo a $5,0 \mathrm{~m}$ e profundidade, temperatura atmosférica e umidade relativa do ar, estando esses dados dispostos na tabela 20 constante no Apêndice.

\subsubsection{Semeadura}

A semeadura foi feita no dia $05 / 11$, dentro do período de segurança aceitável pela pesquisa, através da plantadeira Turbo-max de plantio direto, que realiza a abertura do sulco, colocação da semente, do adubo e fechamento do sulco em operação única em 3 linhas, espaçadas de $0,80 \mathrm{~m}$ cada. 


\subsubsection{Sementes}

Utilizaram-se sementes certificadas do cultivar IAC-20, deslintadas quimicamente (sementes "peladas") e tratadas com carbofuran + carboxin-thiran* nas doses de $21,0 \mathrm{~g}$ i. a., $52,5 \mathrm{~g}$ i. $+52,5 \mathrm{~g}$ i. a por $30 \mathrm{~kg}$ de sementes.

A semeadura resultou no número de 32 sementes/metro linear, com consumo total de $8,5 \mathrm{~kg}$ de semente, colocadas a aproximadamente $5,0 \mathrm{~cm}$ de profundidade.

\subsubsection{Adubação}

O planejamento da adubação foi determinado segundo GRIDI-PAPP et al (1992), de acordo com o resultado da análise química do solo da área experimental exposto na Tabela 3 Foi realizada primeiramente a calagem com 1,5 ton/ha de calcáreo dolomítico sendo incorporados $60 \%$ no preparo primário do solo e $40 \%$ no preparo secundário.

TABELA 3 - Análise química do solo da área experimental, realizado pelo laboratório de análises de solos, do Departamento de Solos da ESALQ-USP, Piracicaba- SP.

\begin{tabular}{|c|c|c|c|c|c|c|}
\hline $\mathrm{pH}$ & M.O. & $P$ & $\mathrm{~K}$ & $\mathrm{Ca}$ & $\mathrm{Mg}$ & $\mathrm{H}+\mathrm{Al}$ \\
\hline $\mathrm{CaCl} 2$ & $\%$ & $\mathrm{mg} / \mathrm{cm} 3$ & & $\mathrm{meq} / 100$ & $\mathrm{~cm}^{3}$ & \\
\hline 4,30 & 1.50 & 7,00 & 0.18 & 1,80 & 0,70 & 2.80 \\
\hline
\end{tabular}

\footnotetext{
* Nome comercial: Furadan 350 TS + Vitavax-Thiran PM
} 
A adubação de semeadura foi de $10,0 \mathrm{~kg}$ de $\mathrm{N}, 75,0 \mathrm{~kg}$ de $\mathrm{P}_{2} \mathrm{O}_{5}$ e $57,0 \mathrm{~kg}$ de $\mathrm{K}_{2} \mathrm{O}$ por hectare, usando como fontes de nutrientes o sulfato de amônio, o superfosfato triplo e o cloreto de potássio

\subsection{Condução do experimento}

\subsubsection{Controle fitossanitário}

Aplicou-se paration metílico* na dose de 360,0 g i.a./ha, em 19/11 e 07/12, para o controle da broca do algodoeiro (Eutinobothrus brasiliensis, Hambleton, 1937) Para o controle da lagarta das maçãs (Heliothis virescens, Fabr., 1781) e do bicudo (Anthonomus grandis Boheman, 1843) até os 80 dias, foi utilizado o Endossulfan** na dose de $875 \mathrm{~g}$ i.a./ha, em 4 aplicações nos dias 17/12, 27/12, 14/01 e 29/01. Para continuação do controle do bicudo e, também, da lagarta rosada (Pectinophora gossypiella, Saunder, 1844), realizaram-se 3 aplicações de

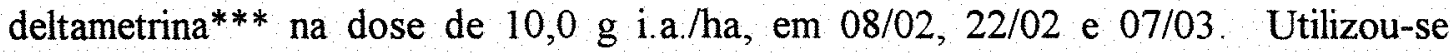
também dodecacloro**** na dose de $33,5 \mathrm{~g}$ i.a./ha para o controle de saúvas (Atta spp), que apareceram durante o ciclo da cultura.

* Nome comercial: Folidol 600 .

** Nome comercial: Thiodan CE.

*** Nome comercial: Decis $50 \mathrm{SC}$.

**** Nome comercial Mirex. 


\subsubsection{Desbaste}

Realizou-se manualmente o desbaste no dia 09/12, 27 dias portanto após a emergência das plântulas, deixando-se 5 plantas por metro linear.

\subsubsection{Adubação em cobertura}

A adubação em cobertura foi realizada manualmente, utilizando sulfato de amônio na dose de $38,0 \mathrm{~kg}$ de $\mathrm{N} / \mathrm{ha}$, depositando-o em linha a distância de $20,0 \mathrm{~cm}$ das ruas da cultura, no dia $22 / 12$.

\subsubsection{Irrigação}

Em decorrência de períodos prolongados de ausência de chuvas, como mostram as tabelas 21 a 28 de dados climatólogicos no Apêndice, realizaram-se duas irrigações suplementares com caminhão pipa equipado com canhão aspersor em 16/11/93 e 06/01/94, com aplicação de 18,0 mm de água em cada irrigação.

\subsubsection{Colheita}

A colheita, de forma manual, foi realizada em três etapas nos dias 23/03, 07/04 e 20/04, que representou o período de 130, 145 e 158 dias após a emergência da cultura $\mathrm{O}$ algodão em caroço da área das parcelas foi colhido manualmente e colocado em sacos de aniagem e individualmente identificados. 


\subsection{Avaliação do experimento}

\subsubsection{Controle das plantas daninhas}

As espécies de plantas daninhas que estiveram presente no experimento, com seus nomes vulgares e dentro de suas respectivas famílias, foram as seguintes:

\section{CLASSE MONOCOTYLEDONEAE}

\section{A. Cyperaceae}

Cyperus rotundus L. (tiririca)

\section{B. Poaceae}

Brachiaria plantaginea (Link) Hitch (capim-marmelada)

Brachiaria mutica (Forsk) Stapf (capim-fino)

Cenchrus echinatus L (capim-carrapicho)

Digitaria horizontalis Willd (capim-colchão)

Eleusine indica (L.) Gaertn (capim pé-de-galinha)

Panicum maximum Jacq. (capim-colonião)

\section{CLASSE DICOTYLEDONAE}

C. Amaranthaceae

Alternanthera ficoidea (L.) R.Br. (apaga-fogo)

Amaranthus spp. (caruru) 


\section{ASTERACEAE}

Acanthospermum australe (Loef) O Kuntze (carrapicho- rasteiro)

Acanthospermum hispidum DC. (carrapicho-de-carneiro)

Ageratum conyzoides L. (mentrasto)

Bidens pilosa L. (picão-preto)

Blainvillea rhomboidea Cass (erva-palha)

Emilia sonchifolia DC. (falsa-serralha)

Erigeron bonariensis L. (buva)

Tagetes minuta L. (cravo-de-defunto)

Xanthium cavanillesii Shouw. (carrapichão)

\section{E. Brassicaceae}

Lepidium virginicum L. (mentruz)

\section{F. Convolvulaceae}

Ipomoea spp. (corda-de-viola)

G. Malvacea

Sida spp. (guanxuma)

\section{Molluginaceae}

Mollugo verticillata L. (capim-tapete)

\section{Papilionaceae}

Indigofera hirsuta L. (anileira) 


\section{J. Portulaceae}

Portulaca oleracea L. (beldroega)

K. Rubiaceae

Richardia brasiliensis Gomez (poaia)

\section{Solanaceae}

Solanum americanum Mill (maria-pretinha)

\subsubsection{Avaliação visual de controle}

Foram realizadas duas avaliações após a aplicação dos herbicidas, em 12/11 - 14 dias após a aplicação (DAA) e em 19/11 - 21 DAA, utilizando uma escala de $0-100 \%$, sendo $0 \%$ nenhum controle a $100 \%$ controle total, comparado com a testemunha sem controle A primeira avaliação visou analisar o controle inicial e a segunda avaliar possíveis rebrotes e controle final.

\subsubsection{Contagem das plantas daninhas}

Essas avaliações foram realizadas através de gabaritos de arame de ferro de $0,5 \times 0,5 \mathrm{~m}\left(0,25 \mathrm{~m}^{2}\right)$. Em cada avaliação foram amostradas 144 gabaritos, num total de $36,0 \mathrm{~m}^{2}$, sendo que na primeira avaliação dias 13 e $16 / 09$, antes do preparo, foi feito de maneira aleatória; na segunda, dias 26 e 27/10 - 40 dias após o preparo, com amostragem de 12 gabaritos em cada tratamento de preparo de solo por bloco, nas 5 avaliações posteriores, dias 19/11 - 21 DAA, 09/12 - 41 DAA, 27 e 29/12 - 61 DAA, 04/02/94 DAA e 21 e 22/03 - 144 DAA (colheita do algodão), foram amostrados 3 gabaritos por subparcela por bloco, com exceção das subparcelas 
testemunhas com controle. As espécies foram identificadas e quantificadas, sendo o resultado expresso em número/ $/ \mathrm{m}^{2} \mathrm{e}$ em densidade relativa (\%), que é a relação do número total de indivíduos da espécie (Ni) pelo número total de indivíduos amostrado (Nt), multiplicado por 100 .

$$
D R(\%)=\frac{N i}{N t} \times 100
$$

\subsubsection{Peso da biomassa seca}

Nas avaliações em 26 e 27/10, 27 e 29/12, 21 e 22/03/94 descritos no item 3.5.2, aproveitou-se para coletar todas as plantas daninhas das áreas amostradas, sendo cortadas rente ao solo, separadas por espécie por subparcela/bloco, lavadas em laboratório e secas em estufa de circulação forçada de ar a $65,0^{\circ}$ até peso constante, sendo a biomassa seca pesada em balança de precisão de $0,1 \mathrm{~g}$, com o resultado expresso em $\mathrm{g} / \mathrm{m}^{2}$. Foi determinada a dominância relativa (\%), que é a relação do peso da matéria seca da espécie (MSi), pelo peso da matéria seca de todas as espécies (MSt), multiplicado por 100

$$
\operatorname{DOr}(\%)=\frac{M S i}{M S t} \times 100
$$




\subsubsection{Comportamento da cultura do algodoeiro}

\subsubsection{Características fitotécnicas}

Realizado o desbaste, selecionaram-se 12 plantas representativas das áreas úteis de cada parcela, que foram objeto das seguintes avaliações:

\subsection{Altura das plantas}

Determinada a distância em centímetros entre o nível do solo e o ápice das plantas, com auxílio de fita métrica. Essa avaliação foi feita quando da primeira colheita.

\subsection{Diâmetro do caule}

Determinado o diâmetro do caule em milímetros a um centímetro acima do nível do solo, com auxílio de um paquímetro. Essa avaliação foi feita quando da primeira colheita.

\subsection{Número de ramos produtivos}

Determinado o número de ramos com maçãs ou capulhos. Essa avaliação foi feita na primeira colheita.

\subsection{Altura de inserção do primeiro ramo produtivo}

Determinada a distância da superficie do solo até a inserção do primeiro ramo produtivo, em centímetros, com o auxílio da fita métrica. Avaliação feita na primeira colheita. 


\subsection{Ocorrência do primeiro capulho}

Determinado o número de dias a partir da emergência das plântulas, em que se formou o primeiro capulho.

\subsection{Número de capulhos por planta}

Determinado pela somátoria das três colheitas, de todos os capulhos das plantas selecionadas, calculando-se posteriormente a média.

\subsection{Peso médio de um capulho}

Determinado pelo peso médio em gramas, de algodão em caroço de 40 capulhos escolhidos ao acaso, das plantas selecionadas. Essa avaliação foi feita na primeira colheita com auxilio de balança de precisão de $0,1 \mathrm{~g}$.

\subsection{Peso de 100 sementes}

Determinado pelo peso médio em gramas, de quatro amostragens ao acaso de 100 sementes dos 40 capulhos selecionados descritos no item 3.5.2.1.7. Essa avaliação foi feita na primeira colheita com auxilio de balança de precisão de $0,1 \mathrm{~g}$

\subsection{Porcentagem de fibras}

Determinado pela relação entre o peso do algodão em caroço (PAC) menos o peso das sementes (PSem) e o peso do algodão em caroço, expresso em porcentagem, dos 40 capulhos selecionados. 


$$
\% \text { FIBRAS }=\frac{P A C-P S e m}{P A C} \times 100
$$

\subsection{Precocidade}

Determinada pela relação entre a produção da primeira colheita e a produção total do algodão em caroço das plantas selecionadas

$$
\text { PRECOCIDADE }(\%)=\frac{\text { Produçãol colheita }}{\text { Produção total }} \times 100
$$

\subsubsection{Produção de algodão em caroço}

O total de algodão em caroço obtido das áreas úteis das parcelas foi pesado e o resultado transformado em quilogramas por hectare. 


\subsubsection{Características tecnológicas da fibra}

Uma amostra de 20 capulhos por subparcela foi enviado à Empresa Paranaense de Classificação de Produtos (CLASPAR), determinando-se:

- Comprimento = "Span $2,5 \% "$, em mm

- Uniformidade = $=$ Span $50 \% / \mathrm{Span} 2,5 \%$, em mm.

- Finura $\quad=$ Micronaire, em índice.

- Tenacidade = Pressley, em g/tex

- Maturidade = Fibras maduras no fibrógrafo digital, em $\%$

\subsection{Análise estatística}

Os resultados obtidos foram submetidos a análise de variância conforme GOMES (1990), aplicando-se o teste F a $5 \%$ e $1 \%$ para testar as diferenças entre os efeitos das parcelas, sub-parcelas e suas interações, com a comparação das médias sendo realizada pelo teste de Tukey a $5 \%$.

Os dados de contagem de plantas daninhas e peso da biomassa seca foram transformadas em $\sqrt{x+0,5}$ e os dados da análise visual de controle das lantas daninhas foram transformadas em arc sen $\sqrt{\frac{x}{100}}$, conforme DEMÉTRIO (1978). 


\section{RESULTADOS E DISCUSSÃO}

\subsection{Comportamento da comunidade infestante}

Do total de espécies daninhas presentes no experimento, apenas Brachiaria mutica, Ageratum conyzoides, Erigeron bonariensis, Lepidium virginicum, Solamum americanum, Tagetes minuta e Xanthium cavanillesii não são citados por ABRHAÃO (1985); GRIDI-PAPP et al (1992), KRANZ (1991) e LEITÃO FILHO et al (1972) como as principais plantas daninhas que ocorrem nos algodoais em nossas condições.

Na Tabela 4 estão apresentados o número e a densidade relativa das espécies daninhas presentes na área experimental quando da primeira avaliação de contagem, anterior à realização dos preparos antecipados de solo. Observa-se que do total relacionado em todo experimento apenas Amaranthus spp, Ipomoea spp e Portulaca oleracea não apareceram nessa primeira contagem, o que veio acontecer apenas nas avaliações posteriores.

A população total de infestantes de $372,77 \mathrm{pl} / \mathrm{m}^{2}$ encontrava-se em estádio avançado de desenvolvimento, tendo a maioria das plantas mais de 6 folhas, e cobrindo totalmente $(100 \%)$ a área experimental. 
TABELA 4 - Densidade média $\left(\mathrm{N}^{\%} / \mathrm{m}^{2}\right)$ e densidade relativa $(\%)$ das espécies infestantes da área experimental, em 16/set/93, antes da realização dos preparos antecipados de solo para a implantação da cultura do algodoeiro em semeadura direta.

\begin{tabular}{lcc}
\hline \multicolumn{1}{c}{ ESPÉCIES DANINHAS } & $\mathrm{n}^{\mathrm{O}} \mathrm{m}^{2}$ & $\%$ \\
\hline Cenchrus echinatus & 34,56 & 9,27 \\
Digitaria horizontalis & 18,94 & 5,08 \\
Brachiaria plantaginea & 13,49 & 3,62 \\
Cyperus rotundus & 11,70 & 3,14 \\
Eleusine indica & 6,52 & 1,75 \\
Panicum maximum & 5,14 & 1,38 \\
Brachiaria mutica & 3,28 & 0,88 \\
Total de monocotiledôneas & 93,63 & 25,12 \\
\hline & & \\
Ageratum conyzoides & 70,02 & 18,78 \\
Blainvillea rhomboidea & 51,42 & 13,80 \\
Indigofera hirsuta & 45,04 & 12,08 \\
Acanthospermum hispidum & 19,64 & 5,27 \\
Emilia sonchifolia & 19,09 & 5,12 \\
Richardia brasiliensis & 16,85 & 4,52 \\
Mollugo verticillata & 12,30 & 3,30 \\
Bidens pilosa & 11,78 & 3,16 \\
Alternanthera ficoidea & 9,84 & 2,64 \\
Sida spp & 3,99 & 1,07 \\
Lepidium virginicum & 3,87 & 1,04 \\
Solanum americanum & 3,43 & 0,92 \\
Tagetes minuta & 3,28 & 0,88 \\
Ipomoea spp & 3,09 & 0,83 \\
Erigeron bonariensis & 2,83 & 0,76 \\
Xanthium cavanillesii & 0,71 \\
Total de dicotiledôneas & 74,88 \\
\hline Total & 100,00 \\
\hline \hline
\end{tabular}


As monocotiledôneas representaram $25,12 \%$ do total de indivíduos, destacando-se Cenchrus echinatus, Digitaria horizontalis e Brachiaria plantaginea como as espécies mais numerosas Devido a essa superioridade, demonstrada durante todo 0 experimento, essas três espécies foram analisadas individualmente a partir da segunda avaliação, englobando as demais plantas dessa classe na denominação de "outras monocotiledôneas".

Dentre as dicotiledôneas, que foram maioria com $74,88 \%$, destacaramse o Ageratum conyzoides, Blainvillea rhomboidea, Indigofera hirsuta e Acanthospermum hispidum. No entanto, já a partir da segunda avaliação Ageratum conyzoides teve grande redução natural na sua população $(74,3 \%)$, fato também ocorrido com OLIVEIRA Jr. (1990), em experimento com cebola, devido a essa espécie ser considerada de inverno, decaindo populacionalmente com os aumentos de temperatura advindos a partir de setembro (DEUBER, 1992) Em virtude disso, a partir da segunda avaliação apenas as três espécies principais $B$. rhomboidea, $I$. hirsuta e A. hispidum foram analisadas individualmente, englobando as demais plantas dessa classe em "outras dicotiledôneas.

Aos 40 dias após a instalação dos tratamentos de preparo do solo, os resultados de contagem das espécies contidas na tabela 5 mostram que para $C$. echinatus, B. plantaginea, A. hispidum e "outras dicotiledôneas", não houve diferença entre grade aradora $(\mathrm{Gr})$, grade aradora + arado $(\mathrm{G}+\mathrm{A})$ e arado $(\mathrm{Ar})$.

Para I. hirsuta, B. rhomboidea, total de monocotiledôneas e dicotiledôneas e total de plantas daninhas $\mathrm{G}+\mathrm{A}$ e Ar não diferiram entre si, mas foram superiores a Gr. As profundidades de trabalho de cada tratamento citados no item 3.3.1. explicam tais resultados, pois segundo CASTRO (1989) a colocação das 
sementes das plantas daninhas a maiores profundidades no solo dificultam a sua germinação, principalmente devido à falta de luminosidade adequada BUHLER \& MESTER (1991) comparando os preparos convencional, mínimo e plantio direto, verificaram que a germinação de plantas daninhas no primeiro $1,0 \mathrm{~cm}$ foi de $40,0 \%$ no plantio direto, $25,0 \%$ no preparo mínimo e $<15,0 \%$ no convencional Para profundidades $>4,0 \mathrm{~cm}$ foi de $25,0 \%$ no convencional, $10,0 \%$ no mínimo e $<5,0 \%$ no plantio direto, onde maiores densidades em razão disso foram obtidas no preparo Mínimo do que no convencional, confirmando os resultados obtidos. Também TANG \& WANG (1986) e BANKS (1992) obtiveram resultados semelhantes.

A pré-incorporação com grade aradora seguida da aração com arado de discos, resultou em melhor controle de $D$. horizontalis do que $\mathrm{Gr}$ e $\mathrm{Ar}$, que não diferiram entre si SEGUY et al. (1984) afirmam que a pré-incorporação ajuda a trabalhar em maior profundidade na aração posterior, com maior controle das plantas daninhas. Esse resultado é confirmado por CORTEZ \& KLENKI (1993) que encontraram melhor controle de $D$. horizontalis com maior movimentação do solo.

Com relação as "outras monocotiledôneas", a densidade para Ar foi menor do que a de $\mathrm{G}+\mathrm{A}$ e $\mathrm{Gr}$, que não diferenciaram-se entre si. Tal resultado é explicado pelo fato de que C. rotundus representou $94,54 \%$ das espécies englobadas nesse conjunto, e cuja reprodução assexuada é grandemente favorecida pela maior movimentação de solo, o que acontece quando se utiliza a grade aradora. FORSTER \& CERDEIRA (1993) estudando a germinação de C. rotundus exemplificaram bem tal situação, quando compararam a germinação de tubérculos inteiros, 1/2, 1/4 e 1/6 
TABELA 5. Densidade média $\left(\mathrm{n}^{\%} / \mathrm{m}^{2}\right)$ das espécies infestantes da área experimental, na avaliação realizada em 26 e $27 / 10 / 93$ - 40 dias após o preparo do solo, para a implantação da cultura do algodoeiro em semeadura direta.

\begin{tabular}{|c|c|c|c|c|c|c|c|c|c|c|c|}
\hline $\begin{array}{l}\text { Preparo do } \\
\text { solo - P }\end{array}$ & $\begin{array}{l}\text { Digitaria } \\
\text { horizon }^{(1)}\end{array}$ & $\begin{array}{l}\text { Cenchrus } \\
\text { echinatus }\end{array}$ & $\begin{array}{l}\text { Brachiaria } \\
\text { plantag. }\end{array}$ & $\begin{array}{l}\text { Outras } \\
\text { monoc. }\end{array}$ & $\begin{array}{l}\text { Total } \\
\text { monoc. }\end{array}$ & $\begin{array}{l}\text { Indigofera } \\
\text { hirsuta }\end{array}$ & $\begin{array}{l}\text { Acanth } \\
\text { hispidum }\end{array}$ & $\begin{array}{l}\text { Blainvil. } \\
\text { rhomboid }\end{array}$ & $\begin{array}{l}\text { Outras } \\
\text { dicot. }\end{array}$ & $\begin{array}{l}\text { Total } \\
\text { dicot. }\end{array}$ & $\begin{array}{l}\text { Total de } \\
\text { P.D. }\end{array}$ \\
\hline Grade & $9,52 \mathrm{a}^{(2)}$ & $6,74 a$ & $5,27 \mathrm{a}$ & $5,81 \mathrm{a}$ & $14,09 a$ & $5,50 \mathrm{a}$ & $5,23 \mathrm{a}$ & $5,38 \mathrm{a}$ & $9,82 \mathrm{a}$ & $13,50 \mathrm{a}$ & $19,53 \mathrm{a}$ \\
\hline Arado & $9,11 \mathrm{a}$ & $5,14 a$ & $4,65 \mathrm{a}$ & $4,20 \mathrm{~b}$ & $12,25 \mathrm{~b}$ & $4,74 \mathrm{~b}$ & $4,67 a$ & $4,23 \mathrm{~b}$ & $8,03 \mathrm{a}$ & $11,37 b$ & $16,76 \mathrm{~b}$ \\
\hline Grade+arado & $7,95 \mathrm{~b}$ & $5,13 a$ & $4,35 \mathrm{a}$ & $5,36 \mathrm{a}$ & $11,72 b$ & $4,33 \mathrm{~b}$ & $5,02 \mathrm{a}$ & $3,99 \mathrm{~b}$ & $8,24 \mathrm{a}$ & $11,35 \mathrm{~b}$ & $16,31 \mathrm{~b}$ \\
\hline $\mathrm{F}$ & $5,39 *$ & $2,69 \mathrm{~ns}$ & $1,76^{\mathrm{ns}}$ & $6,50^{*}$ & $7,17^{*}$ & $5,11^{*}$ & $2.31^{\mathrm{ns}}$ & $20,05 * *$ & $2,67^{\text {ns }}$ & $6,10^{*}$ & $12,05 * *$ \\
\hline C. V. $(\%)$ & 7,91 & 22,61 & 22,50 & 12,71 & 7,69 & 11,33 & 9,85 & 6,54 & 16,37 & 4,50 & 6,30 \\
\hline DMS $(5 \%)$ & 0,87 & 1,63 & 1,34 & 0,81 & 1,22 & 0,69 & 0,62 & 0,37 & 1,80 & 1,45 & 1,39 \\
\hline
\end{tabular}

* F significativo a $5 \%$ de probabilidade

** F significativo a $1 \%$ de probabilidade

NS F não significativo

(1) Dados transformados em $\sqrt{x+0,5}$

(2) Médias seguidas pela mesma letra não diferem entre si ao nível de $5 \%$ de probabilidade pelo teste de Tukey 
do tubérculo, e obtiveram $64,0 \%, 74,0 \%, 62,0 \%$ e $40,0 \%$ de germinação respectivamente, afirmando que a insistência na movimentação do solo, traz maior multiplicação do potencial dispersivo da espécie, aumentando a sua infestação

Os dados da primeira avaliação do peso da matéria seca da comunidade infestante constantes na Tabela 6 mostram que, à exceção de $I$. hirsuta que não apresentou diferença significativa entre os tratamentos de preparo de solo devido ao seu pequeno porte quando da avaliação, as plantas daninhas tiveram o mesmo comportamento obtido para densidade, valendo os mesmos comentários já descritos para tal item.

$\mathrm{O}$ controle de $\mathrm{I}$ hirsuta, $A$. hispidum, $B$. rhomboidea, outras dicotiledôneas e total de dicotiledôneas, juntamente com C. echinatus e B. plantaginea, não mostraram diferença significativa entre os herbicidas de manejo aos 14 DAA conforme consta na Tabela 7 , estando os resultados obtidos, não transformados, acima de $98,0 \%$, mostrando um excelente nível de controle para essas infestantes. Quando dessa aplicação, as gramíneas possuiam média de $2-4$ perfilhos e as latifoliadas $3-4$ folhas.

Obtendo $100,0 \%$ (resultado não transformado) de controle para $D$. horizontalis, glyphosate (Gly) diferiu significativamente do paraquat + diuron (P $+\mathrm{D})$ com $80,6 \%$, sendo este ainda superior ao tratamento isolado de paraquat ( $P$ ar) que obteve apenas $75,4 \%$ de controle Este resultado reafirma a recomendação de RODRIGUES (1985), que em caso da existência de D. horizontalis quando da operação de manejo, não se deve aplicar paraquat pois o controle sobre essa infestante é insuficiente, discordando de LORENZI (1994) que relata que tanto P + D quanto Par controlam essa infestante em níveis acima de $95,0 \%$. 
TABELA 6. Peso da biomassa seca das plantas daninhas $\left(\mathrm{g} / \mathrm{m}^{2}\right)$, na avaliação em 26 e $27 / 10 / 93$ - 40 dias após o preparo do solo, para a implantação da cultura do algodoeiro em semeadura direta.

\begin{tabular}{|c|c|c|c|c|c|c|c|c|c|c|c|}
\hline $\begin{array}{l}\text { Preparo do } \\
\text { solo - P }\end{array}$ & $\begin{array}{l}\text { Digitaria } \\
\text { horizo }(1)\end{array}$ & $\begin{array}{l}\text { Cenchrus } \\
\text { echinatus }\end{array}$ & $\begin{array}{l}\text { Brachiaria } \\
\text { plantag. }\end{array}$ & $\begin{array}{l}\text { Outras } \\
\text { monoc. }\end{array}$ & $\begin{array}{l}\text { Total } \\
\text { monoc. }\end{array}$ & $\begin{array}{l}\text { Indigofera } \\
\text { hirsuta }\end{array}$ & $\begin{array}{l}\text { Acanth. } \\
\text { hispidum }\end{array}$ & $\begin{array}{l}\text { Blainvil, } \\
\text { rhomboid. }\end{array}$ & $\begin{array}{l}\text { Outras } \\
\text { dicot. }\end{array}$ & $\begin{array}{l}\text { Total } \\
\text { dicot. }\end{array}$ & $\begin{array}{l}\text { Total de } \\
\text { P.D. }\end{array}$ \\
\hline Grade & $5,35 \mathrm{a}^{(2)}$ & $4,28 \mathrm{a}$ & $3,71 \mathrm{a}$ & $4,06 \mathrm{a}$ & $8,75 \mathrm{a}$ & $2,74 \mathrm{a}$ & $3,20 \mathrm{a}$ & $2,97 \mathrm{a}$ & $6,24 a$ & $8,02 \mathrm{a}$ & $11,88 \mathrm{a}$ \\
\hline Arado & $5,12 a$ & $3,29 a$ & $2,93 \mathrm{a}$ & $2,98 \mathrm{~b}$ & $7,35 \mathrm{~b}$ & $2,52 \mathrm{a}$ & $2,87 \mathrm{a}$ & $2,36 \mathrm{~b}$ & $5,12 \mathrm{a}$ & $6,83 \mathrm{~b}$ & $10,03 \mathrm{~b}$ \\
\hline Grade+arado & $4,48 b$ & $3,28 \mathrm{a}$ & $2,75 a$ & $3,75 \mathrm{a}$ & $7,18 \mathrm{~b}$ & $2,41 \mathrm{a}$ & $2,97 \mathrm{a}$ & $2,24 \mathrm{~b}$ & $5,26 \mathrm{a}$ & $6,80 \mathrm{~b}$ & $9,89 \mathrm{~b}$ \\
\hline $\mathrm{F}$ & $5,39 *$ & $2,70^{\text {ns }}$ & $1,93 \mathrm{~ns}$ & $6,65 *$ & $7,69^{*}$ & $4,68 \mathrm{~ns}$ & $2,30^{\mathrm{ns}}$ & $25,82 * *$ & $2,68 \mathrm{~ns}$ & $5,96 *$ & $10,88^{*}$ \\
\hline C. V. $(\%)$ & 7,81 & 22,10 & 25,04 & 12,02 & 8,56 & 10,68 & 9,46 & 6,07 & 16,19 & 10,55 & 7,18 \\
\hline JMS $(5 \%)$ & 0,48 & 1,01 & 0,99 & 0,54 & 0,83 & 0.34 & 0,35 & 0,19 & 1,14 & 0,96 & 0,95 \\
\hline
\end{tabular}

* F significativo a $5 \%$ de probabilidade

** F significativo a $1 \%$ de probabilidade NS F não significativo

(1) Dados transformados em $\sqrt{x+0,5}$

(2) Médias seguidas pela mesma letra não diferem entre si ao nível de $5 \%$ de probabilidade pelo teste de Tukey 
O baixo nível de controle encontrado para outras monocotiledôneas com dados não transformados, Gly obteve $85,3 \%$, sendo superior a $\mathrm{P}+\mathrm{D}$ e Par que não diferiram entre si, com $68,9 \%$ e $58,4 \%$ de controle respectivamente, deveu-se a alta participação de Cyperus rotundus nessa população de infestantes VICTORIA FILHO (1985) cita essa espécie como uma das mais importantes e de dificil controle em plantio direto, informando que glyphosate oferece níveis de controle acima de $90,0 \%$, o que é confirmado por ALMEIDA (1981). O menor controle obtido no experimento pode ser explicado pela dose utilizada $(3,01$ p.c./ha), quando o fabricante do produto, segundo ANDREI (1990), recomenda 4,0-6,0 I p.c./ha. Os resultados obtidos para Par e P + D confirmam a baixa eficiência desses herbicidas no controle de C. rotundus, conforme relatam ALMEIDA (1981) e RODRIGUES (1985), discordando de LORENZI (1990) que recomenda esses produtos em função de controle entre 85,0 e $95,0 \%$ para C. rotundus.

Os dados de $D$. horizontalis e outras monocotiledôneas indicaram diferença significativa entre os três tratamentos de manejo para o total de monocotiledôneas, sendo Gly superior a $P+D$ e este superior a Par, e também para o total de plantas daninhas, onde Gly superou $P+D$ e Par que, por sua vez não diferiram significativamente entre si.

Houve pequena rebrota de $D$. horizontalis nos tratamentos $\mathrm{P}+\mathrm{D}$ e Par avaliados aos $21 \mathrm{DAA}$, conforme mostra a Tabela 8,0 que reforça a ineficiência desses herbicidas no controle dessa infestante. Também houve rebrota de C. rotundus em todos os tratamentos, alterando portanto os dados de outras monocotiledôneas, e também reforçando a baixa eficiência desses herbicidas no controle dessa Cyperaceae. Por conseguinte o total de monocotiledôneas e o total de plantas 
TABELA 7 Controle das plantas daninhas (\%) pelos herbicidas de manejo aos 14 dias após aplicação, na cultura do algodoeiro em semeadura direta.

\begin{tabular}{|c|c|c|c|c|c|c|c|c|c|c|c|}
\hline Tratamentos & $\begin{array}{l}\text { Digitaria } \\
\text { horizo. }(1)\end{array}$ & $\begin{array}{l}\text { Cenchrus } \\
\text { echinatus }\end{array}$ & $\begin{array}{l}\text { Brachiaria } \\
\text { plantag. }\end{array}$ & $\begin{array}{l}\text { Outras } \\
\text { monoc. }\end{array}$ & $\begin{array}{l}\text { Total } \\
\text { monoc. }\end{array}$ & $\begin{array}{l}\text { Indigofera } \\
\text { hirsuta }\end{array}$ & $\begin{array}{l}\text { Acanth } \\
\text { hispidum }\end{array}$ & $\begin{array}{l}\text { Blainvil. } \\
\text { rhomboid. }\end{array}$ & $\begin{array}{l}\text { Outras } \\
\text { dicot. }\end{array}$ & $\begin{array}{l}\text { Total } \\
\text { dicot }\end{array}$ & $\begin{array}{l}\text { Total } 1 \\
\text { P.D. }\end{array}$ \\
\hline Paraquat & $60,30 c^{(2)}$ & $84,88 \mathrm{a}$ & $85,45 \mathrm{a}$ & $49,87 \mathrm{~b}$ & $63,87 \mathrm{c}$ & $90,00 \mathrm{a}$ & $86,04 \mathrm{a}$ & $86,85 a$ & $85,95 \mathrm{a}$ & $86,34 a$ & 71,45 \\
\hline Paraq + Diuron & $63,93 \mathrm{~b}$ & 87,22 a & $87,84 a$ & $56,13 b$ & $68,03 \mathrm{~b}$ & $90,00 \mathrm{a}$ & $90,00 \mathrm{a}$ & $90,00 \mathrm{a}$ & $87,88 \mathrm{a}$ & $86,45 a$ & 73,90 \\
\hline Gliphosate & $90,00 \mathrm{a}$ & $90,00 \mathrm{a}$ & $90,00 \mathrm{a}$ & 67,45 a & $81,45 \mathrm{a}$ & $90,00 \mathrm{a}$ & $90,00 \mathrm{a}$ & $90,00 \mathrm{a}$ & $90,00 \mathrm{a}$ & $90,00 \mathrm{a}$ & 83,54 \\
\hline $\mathrm{F}$ & $381,63^{* *}$ & $3,19^{\mathrm{NS}}$ & $3,12^{\mathrm{ns}}$ & $22,93 * *$ & $145,22 * *$ & - & $0,50^{\mathrm{ns}}$ & $3,49 \mathrm{~ns}$ & $2,85 \mathrm{~ns}$ & 3,42 ns & 87,98 \\
\hline C. V. $(\%)$ & 4,02 & 6,27 & 5,88 & 11,14 & 3,73 & $\cdots$ & 14,38 & 4,46 & 4,02 & 3,53 & 3,04 \\
\hline DMS (5\%) & 2,99 & 5,60 & 5,32 & 6,71 & 2,76 & $\ldots$ & 12,62 & 4,12 & 3,69 & 4,16 & 2,46 \\
\hline
\end{tabular}

* F significativo a $5 \%$ de probabilidade

** F significativo a $1 \%$ de probabilidade

NS F não significativo

(1) Dados transformados em arc sen $\sqrt{\frac{x}{100}}$.

(2) Médias seguidas pela mesma letra não diferem entre si ao nivel de $5 \%$ de probabilidade pelo teste de Tukey 
TABELA 8. Controle de plantas daninhas (\%) pelos herbicidas de manejo aos 21 dias após aplicação, na cultura do algodoeiro em semeadura direta.

\begin{tabular}{|c|c|c|c|c|c|c|c|c|c|c|c|}
\hline Tratamentos & $\begin{array}{l}\text { Digitaria } \\
\text { horizo. }(1)\end{array}$ & $\begin{array}{l}\text { Cenchrus } \\
\text { echinatus }\end{array}$ & $\begin{array}{l}\text { Brachiaria } \\
\text { plantag. }\end{array}$ & $\begin{array}{l}\text { Outras } \\
\text { monoc. }\end{array}$ & $\begin{array}{l}\text { Total } \\
\text { monoc. }\end{array}$ & $\begin{array}{l}\text { Indigofera } \\
\text { hirsuta }\end{array}$ & $\begin{array}{l}\text { Acanth } \\
\text { hispidum }\end{array}$ & $\begin{array}{l}\text { Blainvil } \\
\text { rhomboid. }\end{array}$ & $\begin{array}{l}\text { Outras } \\
\text { dicot. }\end{array}$ & $\begin{array}{l}\text { Total } \\
\text { dicot }\end{array}$ & $\begin{array}{l}\text { Total de } \\
\text { P.D. }\end{array}$ \\
\hline Paraquat & $58,35 \mathrm{C}^{(2)}$ & $84,88 \mathrm{a}$ & $85,45 a$ & $48,86 b$ & $62,48 \mathrm{c}$ & $90,00 \mathrm{a}$ & $86,04 a$ & $86,85 a$ & $86,95 a$ & $86,34 a$ & $69,39 \mathrm{~b}$ \\
\hline Paraq + Diuron & $63,20 \mathrm{~b}$ & $72,22 \mathrm{a}$ & $87,84 \mathrm{a}$ & $55,51 \mathrm{~b}$ & $67,27 \mathrm{~b}$ & $90,00 \mathrm{a}$ & $90,00 \mathrm{a}$ & $90,00 \mathrm{a}$ & $87,18 \mathrm{a}$ & $86,45 a$ & $72,82 b$ \\
\hline Gliphosate & $90,00 \mathrm{a}$ & $90,00 \mathrm{a}$ & $90,00 \mathrm{a}$ & $66,77 a$ & $86,70 \mathrm{a}$ & $90,00 \mathrm{a}$ & $90,00 \mathrm{a}$ & $90,00 \mathrm{a}$ & $90,00 \mathrm{a}$ & $90,00 \mathrm{a}$ & $83,03 \mathrm{a}$ \\
\hline $\mathrm{F}$ & $455,50^{* *}$ & $3,19^{\mathrm{NS}}$ & $3,12^{\mathrm{NS}}$ & $24,88^{* *}$ & $148,58^{* *}$ & - & $0,50^{\mathrm{NS}}$ & $3,49 \mathrm{NS}$ & $2,85^{N S}$ & $3,42^{\mathrm{NS}}$ & $100,50^{* *}$ \\
\hline C. V. $(\%)$ & 3,92 & 6,27 & 5,88 & 11,01 & 3,82 & - & 14,38 & 4,46 & 4,02 & 3,53 & 3,62 \\
\hline $\operatorname{DMS}(5 \%)$ & 2,88 & 5,60 & 5,32 & 6,68 & 2,79 & - & 12,62 & 4,12 & 3,69 & 4,16 & 3,45 \\
\hline
\end{tabular}

* F significativo a $5 \%$ de probabilidade

** F significativo a $1 \%$ de probabilidade

NS F não significativo

(1) Dados transformados em arc sen $\sqrt{\frac{x}{100}}$.

(2) Médias seguidas pela mesma letra não diferem entre si ao nível de $5 \%$ de probabilidade pelo teste de Tukey 
daninhas tiveram pequena alteração, diminuindo a porcentagem de controle. Os outros grupos de plantas daninhas não sofreram alteração, bem como a relação de níveis de controle entre os tratamentos manteve-se como da primeira avaliação do manejo, aos 14 DAA.

Nas Tabelas 9 a 11 são apresentados os resultados da densidade da comunidade infestante aos 21,41 e 61 DAA. Observa-se que não houve significância para a interação entre os tratamentos de preparo de solo x manejo em nenhuma dessas avaliações.

Individualmente apenas D. horizontalis manteve, aos 21 DAA (Tab. 9), diferença significativa com relação aos preparos de solo, sendo $\mathrm{G}+\mathrm{A}$ igual ao $\mathrm{Ar}$ mas superior a Gr que por sua vez igualou-se ao Ar. Com a evolução da população de infestantes essa significância não mais aconteceu.

Mesmo com os demais tratamentos não apresentando individualmente diferenças significativas, verifica-se, de maneira geral, menor densidade de infestantes em $\mathrm{G}+\mathrm{A}$, seguido de $\mathrm{Ar}$ e por último $\mathrm{Gr}$ A somatória desses números resulta em diferenças significativas para total de monocotiledôneas e total de plantas daninhas aos 21 DAA (Tab. 9), total de monocotiledôneas, total de dicotiledôneas e total de plantas daninhas aos 41 DAA (Tab 10) e de total de dicotiledôneas e total de plantas daninhas aos 61 DAA (Tab. 11).

Com relação aos herbicidas de manejo, a avaliação aos 21 DAA mostra a baixa eficiencia de Par e P $+\mathrm{D}$ no controle de $D$. horizontalis e melhor controle pelo Gly de outras monocotiledôneas, devido a C rotundus. Mesmo o conjunto das demais infestantes mostrando uniformidade entre os tratamentos com 
herbicida, o total de plantas daninhas foi significativamente inferior em Gly em relação a P + D e Par que não diferenciaram-se entre si

$\mathrm{Na}$ evolução da comunidade infestante as diferenças tenderam a se minimizar, como mostram as Tabelas 10 e 11 , onde apenas para D. horizontalis manteve-se diferença significativa entre Gly e os outros herbicidas, refletindo por conseguinte no total de monocotiledôneas e total de plantas daninhas.

A comparação de densidade entre os tratamentos de herbicidas de manejo e a testemunha sem controle das infestantes (Test $\mathrm{s} / \mathrm{c}$ ), mostra que as diferenças significativas encontradas para todas as variáveis analisadas aos 21 DAA sofre uma queda a partir de 41 DAA. No entanto, como existe diferença na época de desenvolvimento das infestantes, onde na Test $\mathbf{s} / \mathrm{c}$ a germinação aconteceu a partir do preparo do solo, anterior portanto aos demais tratamentos, o comportamento em tamanho de plantas é diferenciado e uma avaliação precisa deve-se realizar, neste caso, pelo acúmulo de biomassa seca, o que é feito através da Tabela 12 , na avaliação aos 61 DAA.

Em função do maior desenvolvimento das infestantes na Test s/c, inclusive com plantas de D. horizontalis e C. echinatus em fase de maturação, houve grande diferença entre o peso da biomassa seca entre esse tratamento e os que receberam aplicação de herbicidas de manejo. Entre os herbicidas no entanto, apenas o controle ineficiente de $D$. horizontalis por Par e $\mathrm{P}+\mathrm{D}$ resultaram em diferença significativa em relação ao Gly, que devido a isso também obteve menor peso da biomassa seca para total de monocotiledôneas e total de plantas daninhas.

Com relação aos tratamentos de preparo do solo, não se constatou diferença significativa nas avaliações individuais das infestantes. No entanto, verifica- 
TABELA 9. Densidade média $\left(\mathrm{n}^{\circ} / \mathrm{m}^{2}\right)$ das espécies infestantes da área experimental, na avaliação realizada em $19 / 11 / 93$ - 21 D.A.A., na cultura do algodoeiro em semeadura direta.

\begin{tabular}{|c|c|c|c|c|c|c|c|c|c|c|c|}
\hline $\begin{array}{l}\text { Preparo do } \\
\text { solo-P }\end{array}$ & $\begin{array}{l}\text { Digitaria } \\
\text { horizon }^{(1)}\end{array}$ & $\begin{array}{l}\text { Cenchrus } \\
\text { echinatus }\end{array}$ & $\begin{array}{l}\text { Brachiaria } \\
\text { plantag. }\end{array}$ & $\begin{array}{l}\text { Outras } \\
\text { monoc. }\end{array}$ & $\begin{array}{l}\text { Total } \\
\text { monoc. }\end{array}$ & $\begin{array}{l}\text { Indigofera } \\
\text { hirsuta }\end{array}$ & $\begin{array}{l}\text { Acanth. } \\
\text { hispidum }\end{array}$ & $\begin{array}{l}\text { Blainvil } \\
\text { rhomboid. }\end{array}$ & $\begin{array}{l}\text { Outras } \\
\text { dicot. }\end{array}$ & $\begin{array}{l}\text { Total } \\
\text { dicot: }\end{array}$ & $\begin{array}{l}\text { Total de } \\
\text { P.D. }\end{array}$ \\
\hline Grade & $4,83 \mathrm{a}(2)$ & $2,57 \mathrm{a}$ & $2,06 a$ & $3,65 a$ & $7,02 a$ & $2,00 \mathrm{a}$ & $2,09 a$ & $1,79 \mathrm{a}$ & $3,27 a$ & $4,34 a$ & $8,51 a$ \\
\hline Arado & $4,65 \mathrm{ab}$ & $2,07 \mathrm{a}$ & $1,88 a$ & $3,23 a$ & $6,44 a b$ & $1,79 a$ & $1,96 a$ & $1,69 a$ & $2,67 a$ & $3,80 a$ & $7,83 a b$ \\
\hline Grade+arado & $4,32 \mathrm{~b}$ & $2,06 \mathrm{a}$ & $1,78 \mathrm{a}$ & $3,41 \mathrm{a}$ & $6,19 \mathrm{~b}$ & $1,68 \mathrm{a}$ & $1,95 \mathrm{a}$ & $1,58 \mathrm{a}$ & $2,83 \mathrm{a}$ & $3,76 \mathrm{a}$ & $7,44 b$ \\
\hline ki & $7,21^{*}$ & $3,08^{\mathrm{NS}}$ & $1,10^{\mathrm{NS}}$ & $2,47^{\mathrm{NS}}$ & $5,53^{*}$ & $3,92^{\mathrm{NS}}$ & $0,87^{\mathrm{NS}}$ & $4,67^{\mathrm{NS}}$ & $3,76^{\mathrm{NS}}$ & $5,12^{\mathrm{NS}}$ & $10,62^{*}$ \\
\hline C. V. $(\%)$ & 4,15 & 14,82 & 13,88 & 7,96 & 5,57 & 8,86 & 8,36 & 5,74 & 10,91 & 7,23 & 4,44 \\
\hline DMS (5\%) & 0,41 & 0,71 & 0,57 & 0,59 & 0,79 & 0,35 & 0,36 & 0,22 & 0,69 & 0,62 & 0,76 \\
\hline \multicolumn{12}{|l|}{$\begin{array}{l}\text { Manejo de plantas } \\
\text { daninhas - } \mathrm{M}\end{array}$} \\
\hline Test. S/C & $9,18 a$ & $6,09 a$ & $5,02 a$ & $5,28 \mathrm{a}$ & $13,27 a$ & $5,18 \mathrm{a}$ & $5,26 a$ & $4,82 a$ & $9,08 \mathrm{a}$ & $12,73 a$ & $18,41 a$ \\
\hline Paraquat & $4,59 \mathrm{~b}$ & $1,11 \mathrm{~b}$ & $1,10 \mathrm{~b}$ & $3,42 b$ & $5,87 \mathrm{~b}$ & $0,70 \mathrm{~b}$ & $1,17 \mathrm{~b}$ & $0,86 \mathrm{~b}$ & $1,01 \mathrm{~b}$ & $1,49 \mathrm{~b}$ & $6,05 b$ \\
\hline Paraq+Diuron & $3,92 \mathrm{c}$ & $1,02 b$ & $0,81 \mathrm{~b}$ & $2,92 \mathrm{~b}$ & $4,96 \mathrm{c}$ & $0,70 \mathrm{~b}$ & $0,86 b$ & $0,70 \mathrm{~b}$ & $0,92 \mathrm{~b}$ & $1,08 \mathrm{~b}$ & $5,04 b$ \\
\hline Glyphosate & $0,70 \mathrm{~d}$ & $0,70 \mathrm{~b}$ & $0,70 \mathrm{~b}$ & $2,10 \mathrm{c}$ & $2,10 \mathrm{~d}$ & $0,70 \mathrm{~b}$ & $0,70 \mathrm{~b}$ & $0,70 \mathrm{~b}$ & $0,70 \mathrm{~b}$ & $0,70 \mathrm{~b}$ & $2,30 \mathrm{c}$ \\
\hline $\mathrm{F}$ & $536,64^{* *}$ & $152,88^{* *}$ & $130,55^{* *}$ & $90,60^{* *}$ & $507,30^{* *}$ & $522,43^{* *}$ & $273,71^{* *}$ & $202,15^{* *}$ & $214,60 * *$ & $618,09^{* *}$ & $587,40^{* *}$ \\
\hline C.V. $(\%)$ & 11,35 & 32,25 & 33,00 & 14,30 & 11,17 & 18,57 & 22,82 & 27,88 & 33,11 & 20,27 & 12,85 \\
\hline DMS $(5 \%)$ & 0,58 & 0,80 & 0,70 & 0,54 & 0,81 & 0,39 & 0,51 & 0,55 & 1,08 & 0,90 & 1,14 \\
\hline Interação PxM (F) & $2,41^{N S}$ & $2,26^{\mathrm{NS}}$ & $1,54^{\mathrm{NS}}$ & $2,37^{\mathrm{NS}}$ & $2,39^{\mathrm{NS}}$ & $2,17^{\mathrm{NS}}$ & $0,91^{\mathrm{NS}}$ & $2,36^{\mathrm{NS}}$ & $1,65^{\mathrm{NS}}$ & $2,43^{\mathrm{NS}}$ & $2,28^{\mathrm{NS}}$ \\
\hline
\end{tabular}

* F significativo a $5 \%$ de probabilidade ** F significativo a $1 \%$ de probabilidade NS F não significativo

(1) Dados transformados em $\sqrt{x+0,5}$

(2) Médias seguidas pela mesma letra não diferem entre si ao nível de $5 \%$ de probabilidade pelo teste de Tukey 
TABELA 10. Densidade média $\left(\mathrm{n}^{\circ} / \mathrm{m}^{2}\right)$ das espécies infestantes da área experimental, na avaliação realizada em $09 / 23 / 93$ - 41 D.A.A., na cultura do algodoeiro em semeadura direta

\begin{tabular}{|c|c|c|c|c|c|c|c|c|c|c|c|}
\hline $\begin{array}{l}\text { Preparo do } \\
\text { solo-P }\end{array}$ & $\begin{array}{l}\text { Digitaria } \\
\text { horizon }\end{array}$ & $\begin{array}{l}\text { Cenchrus } \\
\text { echinatus }\end{array}$ & $\begin{array}{l}\text { Brachiaria } \\
\text { plantag. }\end{array}$ & $\begin{array}{l}\text { Outras } \\
\text { monoc. }\end{array}$ & $\begin{array}{l}\text { Total } \\
\text { monoc. }\end{array}$ & $\begin{array}{l}\text { Indigofera } \\
\text { hirsuta }\end{array}$ & $\begin{array}{l}\text { Acanth. } \\
\text { hispidum }\end{array}$ & $\begin{array}{l}\text { Blainvil. } \\
\text { rhomboid. }\end{array}$ & $\begin{array}{l}\text { Outras } \\
\text { dicot. }\end{array}$ & $\begin{array}{l}\text { Total } \\
\text { dicot }\end{array}$ & $\begin{array}{l}\text { Total de } \\
\text { P.D. }\end{array}$ \\
\hline Grade & $6,94 a^{(2)}$ & $5,54 a$ & $4,52 \mathrm{a}$ & $4,31 \mathrm{a}$ & $10,86 a$ & $4,82 \mathrm{a}$ & $4,42 \mathrm{a}$ & $4,38 a$ & $8,01 a$ & $11,19 a$ & $15,79 a$ \\
\hline Arado & $6,66 \mathrm{a}$ & $5,15 a$ & $4,25 \mathrm{a}$ & $4,00 \mathrm{a}$ & $10,28 \mathrm{ab}$ & $4,35 \mathrm{a}$ & $4,10 \mathrm{a}$ & $3,90 \mathrm{a}$ & $7,22 \mathrm{a}$ & $10,17 \mathrm{~b}$ & $14,47 \mathrm{~b}$ \\
\hline Gradetarado & $6,36 \mathrm{a}$ & $5,11 \mathrm{a}$ & $4,12 \mathrm{a}$ & $4,19 \mathrm{a}$ & $10,03 b$ & $4,25 \mathrm{a}$ & $4,11 a$ & $3,84 a$ & $7,25 \mathrm{a}$ & $10,10 \mathrm{~b}$ & $14,24 \mathrm{~b}$ \\
\hline F & $1,37^{\mathrm{NS}}$ & $4,81^{\mathrm{NS}}$ & $2,01^{\mathrm{NS}}$ & $3,94^{\mathrm{NS}}$ & $8,91^{*}$ & $5,09^{\mathrm{NS}}$ & $4,50^{\mathrm{NS}}$ & $1,97^{\mathrm{NS}}$ & $4,26^{\mathrm{NS}}$ & $7,37^{*}$ & $15,75^{* *}$ \\
\hline C. V. $(\%)$ & 7,84 & 3,71 & 6,67 & 3,81 & 3,51 & 5,98 & 4,14 & 10,42 & 5,77 & 4,26 & 2,84 \\
\hline $1 D M S(5 \%)$ & 1,13 & 0,43 & 0,62 & 0,35 & 0,79 & 0,58 & 0,37 & 0,91 & 0,93 & 0,97 & 0,91 \\
\hline \multicolumn{12}{|l|}{$\begin{array}{l}\text { Manejo de plantas } \\
\text { daninhas - M }\end{array}$} \\
\hline Test $\mathrm{S} / \mathrm{C}$ & $8,68 a$ & $5,98 \mathrm{a}$ & $4,75 a$ & $4,99 a$ & $12,64 a$ & $4,91 \mathrm{a}$ & $4,99 a$ & $4,55 a$ & $8,58 \mathrm{a}$ & $12,03 a$ & $17,46 a$ \\
\hline Paraqual & $6,66 b$ & $5,18 \mathrm{~b}$ & $4,09 \mathrm{a}$ & $4,05 b$ & $10,19 b$ & $4,37 a b$ & $3,91 \mathrm{~b}$ & $3,88 \mathrm{a}$ & $7,16 b$ & $10,01 \mathrm{~b}$ & $14,28 \mathrm{~b}$ \\
\hline Paraq + Diuron & $6,49 \mathrm{~b}$ & $5,23 \mathrm{~b}$ & $4,11 a$ & $4,03 b$ & $10,11 \mathrm{~b}$ & $4,30 b$ & $3,94 b$ & $3,93 \mathrm{a}$ & $7,12 b$ & $9,94 b$ & $14,17 b$ \\
\hline Glyphosate & $4,73 c$ & $5,16 b$ & $4,24 a$ & $3,86 \mathrm{~b}$ & $9,00 \mathrm{c}$ & $4,31 \mathrm{~b}$ & $4,00 \mathrm{~b}$ & $3,79 a$ & $7,13 b$ & $9,96 \mathrm{~b}$ & $13,42 \mathrm{c}$ \\
\hline $\mathrm{F}$ & $75,55^{* *}$ & $5,72^{* *}$ & $1,82^{\mathrm{NS}}$ & $13,87^{* *}$ & $67,72^{* *}$ & $4,42^{*}$ & $6,43^{* *}$ & $1,59^{\mathrm{NS}}$ & $8,19^{* *}$ & $20,55^{* *}$ & $56,82^{* *}$ \\
\hline C.V. $(\%)$ & 9,69 & 10,62 & 18,26 & 11,25 & 6,16 & 10,90 & 16,85 & 23,52 & 11,68 & 7,49 & 5,55 \\
\hline DMS $(5 \%)$ & 0,72 & 0,64 & 0,87 & 0,53 & 0,72 & 0,54 & 0,79 & 1,06 & 0,98 & 0,88 & 0,72 \\
\hline Interação PxM (F) & $1,49^{\mathrm{NS}}$ & $2,07^{\mathrm{NS}}$ & $1,18^{\mathrm{NS}}$ & $2,38^{\mathrm{NS}}$ & $2,43^{\mathrm{NS}}$ & $0,75^{\mathrm{NS}}$ & $0,11^{\mathrm{NS}}$ & $0,41^{\mathrm{NS}}$ & $1,20^{\mathrm{NS}}$ & $1,91^{\mathrm{NS}}$ & $2,32^{\mathrm{NS}}$ \\
\hline
\end{tabular}

* F significativo a $5 \%$ de probabilidade

** F significativo a $1 \%$ de probabilidade

NS F não significativo

(1) Dados transformados em $\sqrt{x+0,5}$

(2) Médias seguidas pela mesma letra não diferem entre si ao nível de $5 \%$ de probabilidade pelo teste de Tukey 
TABELA 11. Densidade média $\left(\mathrm{n}^{\circ} / \mathrm{m}^{2}\right)$ das espécies infestantes da área experimental, na avaliação realizada em 27 e $29 / 12 / 93$ - 61 D.A.A., na cultura do

\begin{tabular}{|c|c|c|c|c|c|c|c|c|c|c|c|}
\hline $\begin{array}{l}\text { Preparo do } \\
\text { solo-P }\end{array}$ & $\begin{array}{l}\text { Digitaria } \\
\text { horizon }(1)\end{array}$ & $\begin{array}{l}\text { Cenchrus } \\
\text { echinatus }\end{array}$ & $\begin{array}{l}\text { Brachiaria } \\
\text { plantag. }\end{array}$ & $\begin{array}{l}\text { Outras } \\
\text { monoc. }\end{array}$ & $\begin{array}{l}\text { Total } \\
\text { monoc. }\end{array}$ & $\begin{array}{l}\text { Indigofera } \\
\text { hirsuta }\end{array}$ & $\begin{array}{l}\text { Acanth. } \\
\text { hispidum }\end{array}$ & $\begin{array}{l}\text { Blainvil } \\
\text { rhomboid. }\end{array}$ & $\begin{array}{l}\text { Outras } \\
\text { dicot. }\end{array}$ & $\begin{array}{l}\text { Total } \\
\text { dicot. }\end{array}$ & $\begin{array}{l}\text { Total de } \\
\text { P.D. }\end{array}$ \\
\hline Grade & $7,10 \mathrm{a}^{(2)}$ & $5,98 a$ & $4,68 \mathrm{a}$ & $4,55 \mathrm{a}$ & $11,34 a$ & $5,01 a$ & $4,45 a$ & $4,43 a$ & $8,19 a$ & $11,47 a$ & $16,14 a$ \\
\hline Arado & $6,70 \mathrm{a}$ & $5,30 \mathrm{a}$ & $4,37 a$ & $4,21 \mathrm{a}$ & $10,44 a$ & $4,64 \mathrm{a}$ & $4,06 \mathrm{a}$ & $3,90 a$ & $7,42 \mathrm{a}$ & $10,45 \mathrm{ab}$ & $14,78 \mathrm{ab}$ \\
\hline Gradetarado & $6,38 a$ & $5,21 \mathrm{a}$ & $4,25 a$ & $4,08 \mathrm{a}$ & $10,18 \mathrm{a}$ & $4,45 \mathrm{a}$ & $4,13 \mathrm{a}$ & $3,89 \mathrm{a}$ & $7,40 \mathrm{a}$ & $10,34 b$ & $14,50 \mathrm{~b}$ \\
\hline $\mathrm{F}$ & $3,02^{\mathrm{NS}}$ & $3,20^{\mathrm{NS}}$ & $0,92^{\mathrm{NS}}$ & $4,33^{\mathrm{NS}}$ & $5,02^{\mathrm{NS}}$ & $2,09^{\mathrm{NS}}$ & $3,93^{\mathrm{NS}}$ & $2,45^{\mathrm{NS}}$ & $2,98^{\mathrm{NS}}$ & $5,91^{*}$ & $6,32 *$ \\
\hline C. V. $(\%)$ & 6,14 & 8,58 & 10,33 & 5,50 & 5,09 & 8,43 & 5,01 & 9,72 & 6,82 & 4,76 & 4,59 \\
\hline $\operatorname{DMS}(5 \%)$ & 0,89 & 1,02 & 0,99 & 0,51 & 1,17 & 0,86 & 0,45 & 0,86 & 1,13 & 1,11 & 1,50 \\
\hline \multicolumn{12}{|l|}{$\begin{array}{l}\text { Manejo de plantas } \\
\text { daninhas - M }\end{array}$} \\
\hline Test. S/C & $7,51 \mathrm{a}$ & $5,38 a$ & $4,56 a$ & $4,35 \mathrm{a}$ & $11,20 \mathrm{a}$ & $4,71 \mathrm{a}$ & $4,35 a$ & $3,79 a$ & $7,66 \mathrm{a}$ & $10,75 a$ & $15,54 a$ \\
\hline Paraquat & $7,12 a$ & $5,59 a$ & $4,38 a$ & $4,37 a$ & $10,94 a$ & $4,67 \mathrm{a}$ & $4,20 \mathrm{a}$ & $4,12 \mathrm{a}$ & $7,70 \mathrm{a}$ & $10,73 a$ & $15,33 \mathrm{a}$ \\
\hline Paraq+Diuron & $7,04 a$ & $5,51 \mathrm{a}$ & $4,34 \mathrm{a}$ & $4,29 a$ & $10,80 \mathrm{a}$ & $4,70 \mathrm{a}$ & $4,19 a$ & $4,17 a$ & $7,68 \mathrm{a}$ & $10,77 \mathrm{a}$ & $15,24 \mathrm{a}$ \\
\hline Glyphosate & $5,23 b$ & $5,51 \mathrm{a}$ & $4,44 a$ & $4,12 \mathrm{a}$ & $9,68 \mathrm{~b}$ & $4,72 \mathrm{a}$ & $4,13 a$ & $4,21 \mathrm{a}$ & $7,64 a$ & $10,74 a$ & $14,45 b$ \\
\hline F & $20,58^{* *}$ & $1,55^{\mathrm{NS}}$ & $1,24 \mathrm{NS}$ & $1,84^{\mathrm{NS}}$ & $11,08^{\mathrm{NS}}$ & $1,02^{\mathrm{NS}}$ & $1,45^{\mathrm{NS}}$ & $1,53^{\mathrm{NS}}$ & $1,01^{\mathrm{NS}}$ & $1,00^{\mathrm{NS}}$ & $6,16^{* *}$ \\
\hline C.V. $(\%)$ & 11,52 & 7,51 & 15,37 & 10,09 & 6,57 & 10,35 & 11,48 & 22,47 & 9,56 & 4,95 & 4,39 \\
\hline DMS (5\%) & 0,86 & 0,46 & 0,76 & 0,48 & 0,78 & 0,54 & 0,54 & 1,02 & 0,82 & 0,59 & 0,74 \\
\hline Interação PxM (F) & $0,72^{\mathrm{NS}}$ & $2,40^{\mathrm{NS}}$ & $0,23^{\mathrm{NS}}$ & $1,89^{\mathrm{NS}}$ & $2,42^{\mathrm{NS}}$ & $0,77^{\mathrm{NS}}$ & $0,42^{\mathrm{NS}}$ & $0,53^{\mathrm{NS}}$ & $1,28^{\mathrm{NS}}$ & $2,33^{\mathrm{NS}}$ & $2,28^{\mathrm{NS}}$ \\
\hline
\end{tabular}

* F significativo a $5 \%$ de probabilidade

*** F significativo a $1 \%$ de probabilidade

NS F não significativo

(1) Dados transformados em $\sqrt{x+0,5}$

(2) Médias seguidas pela mesma letra não diferem entre si ao nível de $\mathbf{5 \%}$ de probabilidade pelo teste de Tukey 
se que na somatória para total de monocotiledôneas, total de dicotiledôneas e, por conseguinte, total de plantas daninhas, o resultado é significativo, mostrando menor peso de biomassa seca para $G+A$ em relação a $G r$, sendo que Ar não diferenciou de ambos. Testanto o preparo com grade pesada e arado na cultura do milho, ANTUNIASSI (1991) só encontrou diferença significativa para as monocotiledôneas, quando com arado obteve $9,05 \mathrm{~g} / \mathrm{m}^{2}$ de matéria seca contra $25,01 \mathrm{~g} / \mathrm{m}^{2}$ com grade pesada Para as dicotiledôneas e total de plantas daninhas não houve significância entre os resultados obtidos

A Tabela 12 mostra ainda que não houve influência da interação preparo do solo $\mathrm{x}$ manejo de plantas daninhas sobre o peso de biomassa seca em nenhum conjunto de infestantes

No tratamento de manejo mantido sem infestantes durante todo o ciclo do algodoeiro (Test c/c), a cultura cobriu totalmente essas parcelas ao redor dos 84 dias após a germinação, confirmando o relatado por YAMAOKA \& PIRES (1993). Nessa época foi realizada a penúltima avaliação da densidade das infestantes nos outros tratamentos, 98 dias DAA, observando-se que em todos eles a cultura do algodoeiro não conseguiu a cobertura total das áreas devido à competição exercida pelas plantas daninhas, o que demonstra a pouca eficiência competitiva da cultura, fato já citado por vários pesquisadores como ALMEIDA (1981) e GRIDI-PAPP et al. (1992) Os resultados dessa avaliação estão apresentados na Tabela 13.

Não houve significância nos resultados das análises individuais entre os tratamentos de preparo do solo, mas a tendência para menor densidade em $\mathrm{G}+\mathrm{A}$ foi 
TABELA 12. Peso da biomassa seca $\left(\mathrm{g} / \mathrm{m}^{2}\right)$ das plantas daninhas, na avaliação realizada em 27 e $29 / 12 / 93$ - 61 D. A A., na cultura do algodoeiro em semeadura direta

\begin{tabular}{|c|c|c|c|c|c|c|c|c|c|c|c|}
\hline $\begin{array}{l}\text { Preparo do } \\
\text { solo-P }\end{array}$ & $\begin{array}{l}\text { Digitaria } \\
\text { horizon }^{(1)}\end{array}$ & $\begin{array}{l}\text { Cenchrus } \\
\text { echinatus }\end{array}$ & $\begin{array}{l}\text { Brachiaria } \\
\text { plantag }\end{array}$ & $\begin{array}{l}\text { Outras } \\
\text { monoc. }\end{array}$ & $\begin{array}{l}\text { Total } \\
\text { monoc. }\end{array}$ & $\begin{array}{l}\text { Indigofera } \\
\text { hirsuta }\end{array}$ & $\begin{array}{l}\text { Acanth. } \\
\text { hispidum }\end{array}$ & $\begin{array}{l}\text { Blainvil. } \\
\text { rhomboid. }\end{array}$ & $\begin{array}{l}\text { Outras } \\
\text { dicot }\end{array}$ & $\begin{array}{l}\text { Total } \\
\text { dicot. }\end{array}$ & $\begin{array}{l}\text { Total de } \\
\text { P.D. }\end{array}$ \\
\hline Grade & $6,25 \mathrm{a}^{(2)}$ & $4,89 a$ & $4,04 \mathrm{a}$ & $4,02 \mathrm{a}$ & $9,65 a$ & $3,81 \mathrm{a}$ & $3,64 a$ & $3,51 \mathrm{a}$ & $6,83 a$ & $9,29 \mathrm{a}$ & $13,35 \mathrm{a}$ \\
\hline Arado & $5,89 \mathrm{a}$ & $4,42 a$ & $3,75 \mathrm{a}$ & $3,57 \mathrm{a}$ & $8,86 \mathrm{ab}$ & $3,51 \mathrm{a}$ & $3,29 a$ & $3,59 \mathrm{a}$ & $6,17 \mathrm{a}$ & $8,39 \mathrm{ab}$ & $12,21 a b$ \\
\hline Gradetarado & $5,57 a$ & $4,39 a$ & $3,63 a$ & $3,71 a$ & $8,60 \mathrm{~b}$ & $3,33 a$ & $3,37 \mathrm{a}$ & $3,61 \mathrm{a}$ & $6,16 a$ & $8,25 \mathrm{~b}$ & $11,91 \mathrm{~b}$ \\
\hline F & $4,22^{\mathrm{NS}}$ & $2,20^{\mathrm{NS}}$ & $1,02^{\mathrm{NS}}$ & $4,71^{\mathrm{NS}}$ & $7,47^{*}$ & $2,42^{\mathrm{NS}}$ & $4,49^{\mathrm{NS}}$ & $4,13^{\mathrm{NS}}$ & $2,98^{\mathrm{NS}}$ & $6,31^{*}$ & $7,17^{*}$ \\
\hline C. V. $(\%)$ & 5,55 & 8,64 & 10,72 & 5,55 & 4,40 & 8,84 & 5,10 & 8,87 & 6,98 & 5,20 & 4,54 \\
\hline $\operatorname{DMS}(5 \%)$ & 0,71 & 0,85 & 0,88 & 0,45 & 0,86 & 0,68 & 0,38 & 0,61 & 0,96 & 0,97 & 1,23 \\
\hline \multicolumn{12}{|l|}{$\begin{array}{l}\text { Manejo de plantas } \\
\text { daninhas - M }\end{array}$} \\
\hline Test. S/C & $7,80 a$ & $5,18 \mathrm{a}$ & $4,95 \mathrm{a}$ & $4,24 a$ & $11,50 \mathrm{a}$ & $4,93 a$ & $4,41 \mathrm{a}$ & $4,00 a$ & $7,73 a$ & $11,01 \mathrm{a}$ & $15,88 \mathrm{a}$ \\
\hline Paraquat & $6,09 \mathrm{~b}$ & $4,42 b$ & $3,42 \mathrm{~b}$ & $3,70 \mathrm{~b}$ & $8,69 b$ & $3,07 \mathrm{~b}$ & $3,12 b$ & $2,87 b$ & $5,98 b$ & $7,80 \mathrm{~b}$ & $11,66 \mathrm{~b}$ \\
\hline Paraq+Diuron & $6,02 b$ & $4,36 b$ & $3,39 \mathrm{~b}$ & $3,63 b$ & $8,52 b$ & $3,09 \mathrm{~b}$ & $3,11 \mathrm{~b}$ & $2,91 \mathrm{~b}$ & $5,90 \mathrm{~b}$ & $7,86 \mathrm{~b}$ & $11,58 \mathrm{~b}$ \\
\hline Glyphosate & $3,70 \mathrm{c}$ & $4,31 b$ & $3,47 \mathrm{~b}$ & $3,49 \mathrm{~b}$ & $7,44 \mathrm{c}$ & $3,11 \mathrm{~b}$ & $3,09 \mathrm{~b}$ & $2,93 \mathrm{~b}$ & $5,94 \mathrm{~b}$ & $7,90 \mathrm{~b}$ & $10,83 \mathrm{c}$ \\
\hline $\mathrm{F}$ & $68,92^{* *}$ & $11,23^{* *}$ & $18,14^{* *}$ & $8,37^{* *}$ & $78,61 * *$ & $58,83^{* *}$ & $25,66^{* *}$ & $6,62^{* *}$ & $18,57^{* *}$ & $112,00^{* *}$ & $176,25^{* *}$ \\
\hline C.V. $(\%)$ & 11,90 & 9,28 & 16,22 & 10,41 & 7,47 & 11,69 & 13,00 & 23,25 & 11,29 & 5,96 & 4,78 \\
\hline DMS $(5 \%)$ & 0,78 & 0,47 & 0,69 & 0,43 & 0,75 & 0,46 & 0,50 & 0,82 & 0,80 & 0,57 & 0,66 \\
\hline Interação PxM (F) & $1,06^{\mathrm{NS}}$ & $1,84^{\mathrm{NS}}$ & $0,42^{\mathrm{NS}}$ & $2,24^{\mathrm{NS}}$ & $2,43^{\mathrm{NS}}$ & $1,54^{\mathrm{NS}}$ & $0,57^{\mathrm{NS}}$ & $1,07^{\mathrm{NS}}$ & $1,70^{\mathrm{NS}}$ & $2,18^{\mathrm{NS}}$ & $2,37^{\mathrm{NS}}$ \\
\hline
\end{tabular}

* F significativo a $5 \%$ de probabilidade

** F significativo a $1 \%$ de probabilidade

NS F não significativo

(1) Dados transformados em $\sqrt{x+0,5}$

(2) Médias seguidas pela mesma letra não diferem entre si ao nivel de $5 \%$ de probabilidade pelo teste de Tukey 
TABELA 13. Densidade média $\left(\mathrm{n}^{\circ} / \mathrm{m}^{2}\right)$ das espécies infestantes da área experimental, na avaliação realizada em 04/02/94 - 98 D.A.A., na cultura do

\begin{tabular}{|c|c|c|c|c|c|c|c|c|c|c|c|}
\hline $\begin{array}{l}\text { Preparo do } \\
\text { solo-P } \\
\end{array}$ & $\begin{array}{l}\text { Digitaria } \\
\text { horizon }^{(1)}\end{array}$ & $\begin{array}{l}\text { Cenchrus } \\
\text { echinatus }\end{array}$ & $\begin{array}{l}\text { Brachiaria } \\
\text { plantag. }\end{array}$ & $\begin{array}{l}\text { Outras } \\
\text { monoc }\end{array}$ & $\begin{array}{l}\text { Total } \\
\text { monoc. }\end{array}$ & $\begin{array}{l}\text { Indigofera } \\
\text { hirsuta }\end{array}$ & $\begin{array}{l}\text { Acanth. } \\
\text { hispidum }\end{array}$ & $\begin{array}{l}\text { Blainvil } \\
\text { hhomboid. }\end{array}$ & $\begin{array}{l}\text { Outras } \\
\text { dicot }\end{array}$ & $\begin{array}{l}\text { Total } \\
\text { dicot. }\end{array}$ & $\begin{array}{l}\text { Total de } \\
\text { P.D. }\end{array}$ \\
\hline Grade & $5,88 a^{(2)}$ & $5,04 a$ & $4,07 a$ & $3,78 \mathrm{a}$ & $9,51 \mathrm{a}$ & $4,69 \mathrm{a}$ & $3,92 \mathrm{a}$ & $3,91 \mathrm{a}$ & $7,52 a$ & $10,44 a$ & $14,13 a$ \\
\hline Arado & $5,77 \mathrm{a}$ & $4,69 a$ & $3,90 \mathrm{a}$ & $3,62 a$ & $9,10 \mathrm{ab}$ & $4,45 \mathrm{a}$ & $3,67 \mathrm{a}$ & $3,59 \mathrm{a}$ & $6,83 a$ & $9,67 \mathrm{~b}$ & $13,28 b$ \\
\hline Gradetarado & $5,38 \mathrm{a}$ & $4,73 \mathrm{a}$ & $3,84 \mathrm{a}$ & $3,50 \mathrm{a}$ & $8,91 \mathrm{~b}$ & $4,35 a$ & $3,74 a$ & $3,52 \mathrm{a}$ & $6,83 \mathrm{a}$ & $9,60 \mathrm{~b}$ & $13,10 \mathrm{~b}$ \\
\hline $\mathrm{F}$ & $3,47^{\mathrm{NS}}$ & $4,50^{\mathrm{NS}}$ & $1,55^{\mathrm{NS}}$ & $4,87^{\mathrm{NS}}$ & $10,46^{*}$ & $2,53^{\mathrm{NS}}$ & $1,96^{\mathrm{NS}}$ & $0,85^{\mathrm{NS}}$ & $3,34^{\mathrm{NS}}$ & $10,03^{*}$ & $44,35^{* *}$ \\
\hline C. V. $(\%)$ & 4,94 & 3,84 & 8,01 & 3,48 & 2,78 & 4,80 & 4,77 & 12,31 & 6,17 & 2,96 & 1,39 \\
\hline $\operatorname{DMS}(5 \%)$ & 0,60 & 0,40 & 0,68 & 0,28 & 0,55 & 0,46 & 0,39 & 0,98 & 0,94 & 0,63 & 0,40 \\
\hline \multicolumn{12}{|l|}{$\begin{array}{l}\text { Manejo de plantas } \\
\text { daninhas - } M\end{array}$} \\
\hline Test, S/C & $5,45 b$ & $3,95 b$ & $3,17 b$ & $3,39 b$ & $8,16 \mathrm{c}$ & $4,31 \mathrm{a}$ & $3,04 \mathrm{~b}$ & $2,81 b$ & $6,10 \mathrm{~b}$ & $8,57 \mathrm{~b}$ & $11,83 \mathrm{~b}$ \\
\hline Paraquat & $6,34 a$ & $5,19 \mathrm{a}$ & $4,11 \mathrm{a}$ & $3,90 \mathrm{a}$ & $9,93 \mathrm{a}$ & $4,49 a$ & $4,04 a$ & $3,90 \mathrm{ab}$ & $7,36 \mathrm{a}$ & $10,29 a$ & $14,30 \mathrm{a}$ \\
\hline Paraq+Dituron & $6,27 a$ & $5,20 \mathrm{a}$ & $4,20 \mathrm{a}$ & $3,80 \mathrm{ab}$ & $9,89 \mathrm{a}$ & $4,59 \mathrm{a}$ & $4,05 \mathrm{a}$ & $3,83 \mathrm{ab}$ & $7,35 \mathrm{a}$ & $10,30 \mathrm{a}$ & $14,28 \mathrm{a}$ \\
\hline Glyphosate & $4,64 \mathrm{c}$ & $5,21 \mathrm{a}$ & $4,27 \mathrm{a}$ & $3,72 \mathrm{ab}$ & $8,99 \mathrm{~b}$ & $4,59 \mathrm{a}$ & $3,99 \mathrm{a}$ & $4,16 \mathrm{a}$ & $7,43 a$ & $10,45 \mathrm{a}$ & $13,77 \mathrm{a}$ \\
\hline F & $33,16^{* *}$ & $22,10^{* *}$ & $9,87^{* *}$ & $3,24^{*}$ & $41,72 * *$ & $1,11^{\mathrm{NS}}$ & $8,78^{* *}$ & $4,19^{*}$ & $6,33^{* *}$ & $17,32^{* *}$ & $33,92 * *$ \\
\hline C.V. $(\%)$ & 8,46 & 9,67 & 14,39 & 11,10 & 4,88 & 9,68 & 15,16 & 27,21 & 12,50 & 7,49 & 5,13 \\
\hline DMS $(5 \%)$ & 0,53 & 0,52 & 0,63 & 0,46 & 0,50 & 0,48 & 0,64 & 1,12 & 0,98 & 0,83 & 0,77 \\
\hline Interação PxM (F) & $2,26^{\mathrm{NS}}$ & $1,87^{\mathrm{NS}}$ & $0,81^{\mathrm{NS}}$ & $1,67^{\mathrm{NS}}$ & $2,31^{N S}$ & $0,96^{\mathrm{NS}}$ & $0,75^{\mathrm{NS}}$ & $0,80^{\mathrm{NS}}$ & $0,93^{\mathrm{NS}}$ & $1,01^{\mathrm{NS}}$ & $2,09^{\mathrm{NS}}$ \\
\hline
\end{tabular}

* F significativo a $5 \%$ de probabilidade

**. $\mathrm{F}$ significativo a $1 \%$ de probabilidade

NS F não significativo

(1) Dados transformados em $\sqrt{x+0,5}$

(2) Médias seguidas pela mesma letra não diferem entre si ao nível de $5 \%$ de probabilidade pelo teste de Tukey 
confirmada no total de monocotiledôneas, total de dicotiledôneas e total de plantas daninhas, apresentando diferenças significativas.

Os tratamentos de herbicidas de manejo mostraram os mesmos resultados para $D$. horizontalis e total de monocotiledôneas das avaliações anteriores, no entanto com a diminuição das diferenças entre esses tratamentos e entre os demais tratamentos também, não houve diferença significativa para o total de plantas daninhas. Observou-se também que a testemunha sem capina passou a possuir menor densidade de infestantes, diferindo significativamente dos demais tratamentos em todas as infestantes com exceção de $I$. hirsuta. Esse comportamento deve-se à competição intra e interespecífica que ao se acentuar diminui a germinação de novas infestantes e compromete a sobrevivência das plantas pré-estabelecidas

Os dados referentes à última avaliação da densidade da comunidade infestante, quando da colheita do algodoeiro, estão apresentados na Tabela 14. A interação entre os tratamentos de preparo do solo $\mathrm{x}$ manejo das plantas daninhas não apresentou diferença significativa.

Os tratamentos de preparo do solo não diferiram estatísticamente entre si em nenhuma análise individual das infestantes, nem no total de monocotiledôneas ou dicotiledôneas. No entanto, na análise do total de plantas daninhas verifica-se que a globalização das infestantes promoveu diferença significativa entre os tratamentos, onde $\mathrm{G}+\mathrm{A}$ se comportou semelhantemente a Ar mas obteve menor densidade que Gr, que por sua vez não diferiu de Ar. Esses resultados confirmam a tendência de se obter uma menor densidade de plantas daninhas em preparos de solo que coloquem os propágulos reprodutivos das plantas daninhas numa profundidade de solo que dificulte sua germinação, em geral maior que $25,0 \mathrm{~cm}$. Vários trabalhos de pesquisa 
TABELA 14. Densidade média $\left(\mathrm{n}^{\circ} / \mathrm{m}^{2}\right)$ das espécies infestantes da área experimental, na avaliação realizada em 21 e $23 / 03 / 94-144$ D.A. A. na

\begin{tabular}{|c|c|c|c|c|c|c|c|c|c|c|c|}
\hline $\begin{array}{l}\text { Preparo do } \\
\text { solo-P }\end{array}$ & $\begin{array}{l}\text { Digitaria } \\
\text { horizon }^{(1)}\end{array}$ & $\begin{array}{l}\text { Cenchrus } \\
\text { echinatus }\end{array}$ & $\begin{array}{l}\text { Brachiaria } \\
\text { plantag. }\end{array}$ & $\begin{array}{l}\text { Outras } \\
\text { monoc. }\end{array}$ & $\begin{array}{l}\text { Total } \\
\text { monoc. }\end{array}$ & $\begin{array}{l}\text { Indigofera } \\
\text { hirsuta }\end{array}$ & $\begin{array}{l}\text { Acanth } \\
\text { hispidum }\end{array}$ & $\begin{array}{l}\text { Blainvil. } \\
\text { rhomboid. }\end{array}$ & $\begin{array}{l}\text { Outras } \\
\text { dicot. }\end{array}$ & $\begin{array}{l}\text { Total } \\
\text { dicot. }\end{array}$ & $\begin{array}{l}\text { Total de } \\
\text { P.D. }\end{array}$ \\
\hline Grade & $5,67 \mathrm{a}^{(2)}$ & $5,27 a$ & $4,14 a$ & $4,19 a$ & $9,72 a$ & $4,83 \mathrm{a}$ & $3,98 \mathrm{a}$ & $4,11 \mathrm{a}$ & $7,62 \mathrm{a}$ & $10,66 \mathrm{a}$ & $14,43 a$ \\
\hline Arado & $5,70 \mathrm{a}$ & $4,86 \mathrm{a}$ & $4,11 \mathrm{a}$ & $3,70 a$ & $9,34 a$ & $4,60 \mathrm{a}$ & $3,82 \mathrm{a}$ & $3,87 a$ & $7,00 \mathrm{a}$ & $10,01 \mathrm{a}$ & $13,69 \mathrm{ab}$ \\
\hline Gradetarado & $5,31 \mathrm{a}$ & $4,79 a$ & $4,16 a$ & $4,01 \mathrm{a}$ & $9,18 \mathrm{a}$ & $4,63 \mathrm{a}$ & $3,81 \mathrm{a}$ & $3,85 \mathrm{a}$ & $7,03 a$ & $10,04 a$ & $13,60 \mathrm{~b}$ \\
\hline $\mathrm{F}$ & $2,12^{\mathrm{NS}}$ & $3,70^{\mathrm{NS}}$ & $0,39^{\mathrm{Ns}}$ & $4,01^{\mathrm{NS}}$ & $3,83^{\mathrm{NS}}$ & $1,21^{\mathrm{NS}}$ & $1,00^{\mathrm{NS}}$ & $0,51^{\mathrm{NS}}$ & $2,10^{\mathrm{NS}}$ & $3,78^{\mathrm{Ns}}$ & $6,64^{*}$ \\
\hline C. V. $(\%)$ & 5,42 & 5,32 & 5,28 & 4,89 & 3,02 & 4,82 & 4,72 & 10,13 & 6,44 & 3,67 & 2,53 \\
\hline $\operatorname{DMS}(5 \%)$ & 0,65 & 0,57 & 0,47 & 0,42 & 0,61 & 0,49 & 0,39 & 0,86 & 1,01 & 0,81 & 0,76 \\
\hline \multicolumn{12}{|l|}{$\begin{array}{l}\text { Manejo de plantas } \\
\text { daninhas - } M\end{array}$} \\
\hline Test. S/C & $5,33 b$ & $4,35 b$ & $3,76 a$ & $4,16 a$ & $8,88 \mathrm{~b}$ & $4,74 a$ & $3,31 \mathrm{~b}$ & $3,55 \mathrm{a}$ & $6,48 b$ & $9,43 b$ & $12,96 b$ \\
\hline Paraquat & $6,22 a$ & $5,18 \mathrm{a}$ & $4,18 \mathrm{a}$ & $4,03 \mathrm{a}$ & $9,92 \mathrm{a}$ & $4,59 \mathrm{a}$ & $4,07 \mathrm{a}$ & $4,00 \mathrm{a}$ & $7,45 \mathrm{ab}$ & $10,41 \mathrm{a}$ & $14,38 \mathrm{a}$ \\
\hline Paraq +Diuron & $6,15 a$ & $5,18 \mathrm{a}$ & $4,26 a$ & $3,95 \mathrm{a}$ & $9,88 \mathrm{a}$ & $4,71 \mathrm{a}$ & $4,07 a$ & $3,92 \mathrm{a}$ & $7,44 a b$ & $10,45 \mathrm{a}$ & $14,38 \mathrm{a}$ \\
\hline Glyphosate & $4,54 \mathrm{c}$ & $5,20 \mathrm{a}$ & $4,34 a$ & $3,86 a$ & $8,97 \mathrm{~b}$ & $4,72 \mathrm{a}$ & $4,03 \mathrm{a}$ & $4,29 a$ & $7,55 \mathrm{a}$ & $10,65 \mathrm{a}$ & $13,91 \mathrm{a}$ \\
\hline $\mathrm{F}$ & $24,89^{* *}$ & $9,21^{* *}$ & $2,95^{\mathrm{NS}}$ & $1,48^{\mathrm{NS}}$ & $20,34^{* *}$ & $0,25^{\mathrm{NS}}$ & $4,16^{*}$ & $1,41^{\mathrm{NS}}$ & $3,87^{*}$ & $7,26^{* *}$ & $12,46^{* *}$ \\
\hline C.V. $(\%)$ & 9,88 & 9,55 & 12,59 & 8,88 & 4,59 & 10,01 & 16,37 & 22,43 & 12,17 & 6,83 & 4,72 \\
\hline DMS $(5 \%)$ & 0,61 & 0,53 & 0,58 & 0,39 & 0,48 & 0,52 & 0,70 & 0,99 & 0,98 & 0,78 & 0,73 \\
\hline Interação PxM (F) & $1,70^{\mathrm{NS}}$ & $2,00^{\mathrm{NS}}$ & $1,20^{\mathrm{NS}}$ & $2,12^{\mathrm{NS}}$ & $1,34^{\mathrm{NS}}$ & $0,66^{\mathrm{NS}}$ & $0,60^{\mathrm{NS}}$ & $1,19^{\mathrm{NS}}$ & $1,35^{\mathrm{NS}}$ & $1,36^{\mathrm{NS}}$ & $1,50^{\mathrm{NS}}$ \\
\hline
\end{tabular}

* F significativo a $5 \%$ de probabilidade

** F significativo a $1 \%$ de probabilidade

NS F não significativo

(1) Dados transformados em $\sqrt{x+0,5}$

(2) Médias seguidas pela mesma letra não diferem entre si ao nível de $5 \%$ de probabilidade pelo teste de Tukey 
comprovam tal afirmação, como BUHLER (1992), ANTUNIASSI (1991), BANKS (1992), CASTRO (1989), TOUCHTON \& REEVES (1988) e KURTS \& HURST (1984)

O baixo nível de controle obtido por Par e $\mathrm{P}+\mathrm{D}$ para $D$. horizontalis, já constatado nas avaliaçõs anteriores e analisado especificamente nos comentários sobre as Tabelas 7 e 8 , resultou em diferença significativa entre esses tratamentos e Gly, refletindo significativamente também no total de monocotiledôneas. Entre as demais variáveis analisadas não houve diferença significativa, resultando numa densidade total de plantas daninhas uniforme entre ostratamentos de herbicidas de

manejo. A eficiência de controle desses herbicidas é relatada também por vários autores como BRUFF \& SHAW (1992), ALMEIDA (1991), HIGGINS et al. (1991), BRUCE \& KELLS (1990) e WIEPKE (1990).

A Test s/c mesmo possuindo, no geral, densidade menor que os tratamentos com herbicidas, apresentou maior peso da biomassa seca para todas as variáveis analisadas, como mostra a Tabela 15. Isso deveu-se ao estádio mais avançado de desenvolvimento da comunidade infestante desse tratamento, pois a mesma não sofreu qualquer intervenção desde as operações de preparo do solo.

Entre os tratamentos de herbicidas de manejo, apenas para $D$. horizontalis apresentou-se diferença significativa, com menor peso da biomassa seca para Gly em relação a $P+D$ e Par, levando a um mesmo resultado para total de monocotiledôneas. Para as demais variáveis, inclusive total de plantas daninhas, não houve diferença entre os tratamentos, obtendo resultado idêntico ao da densidade. 
TABELA15. Peso da biomassa seca das plantas daninhas $\left(\mathrm{g} / \mathrm{m}^{2}\right)$ na avaliação realizada em 21 e $23 / 03 / 94$ - 144 D.A.A., na cultura do algodoeiro em

\begin{tabular}{|c|c|c|c|c|c|c|c|c|c|c|c|}
\hline $\begin{array}{l}\text { Preparo do } \\
\text { solo-P }\end{array}$ & $\begin{array}{l}\text { Digitaria } \\
\text { horizon }^{(1)}\end{array}$ & $\begin{array}{l}\text { Cenchrus } \\
\text { echinatus }\end{array}$ & $\begin{array}{l}\text { Brachiaria } \\
\text { plantag. }\end{array}$ & $\begin{array}{l}\text { Outras } \\
\text { monoc. }\end{array}$ & $\begin{array}{l}\text { Total } \\
\text { monoc. }\end{array}$ & $\begin{array}{l}\text { Indigofera } \\
\text { hirsuta }\end{array}$ & $\begin{array}{l}\text { Acanth } \\
\text { hispidum }\end{array}$ & $\begin{array}{l}\text { Blainvil. } \\
\text { rhomboid. }\end{array}$ & $\begin{array}{l}\text { Outras } \\
\text { dicot. }\end{array}$ & $\begin{array}{l}\text { Total } \\
\text { dicot. }\end{array}$ & $\begin{array}{l}\text { Total de } \\
\text { P.D. }\end{array}$ \\
\hline Grade & $7,77 \mathrm{a}^{(2)}$ & $6,16 a$ & $5,72 a$ & $4,34 a$ & $12,18 \mathrm{a}$ & $6,83 a$ & $4,87 a$ & $5,44 a$ & $9,38 \mathrm{a}$ & $13,65 a$ & $18,28 \mathrm{a}$ \\
\hline Arado & $7,17 \mathrm{a}$ & $6,20 \mathrm{a}$ & $5,49 a$ & $4,01 \mathrm{a}$ & $11,61 \mathrm{a}$ & $6,31 \mathrm{a}$ & $4,57 \mathrm{a}$ & $4,92 a$ & $8,71 \mathrm{a}$ & $13,30 a$ & $17,36 \mathrm{ab}$ \\
\hline Gradetarado & $7,17 a$ & $5,70 \mathrm{a}$ & $5,47 \mathrm{a}$ & $4,00 \mathrm{a}$ & $11,40 \mathrm{a}$ & $6,51 \mathrm{a}$ & $4,37 a$ & $5,06 \mathrm{a}$ & $8,60 \mathrm{a}$ & $12,83 \mathrm{a}$ & $17,12 b$ \\
\hline $\mathrm{F}$ & $0,90^{\mathrm{NS}}$ & $1,98^{\mathrm{NS}}$ & $1,25^{\mathrm{NS}}$ & $3,59^{\mathrm{NS}}$ & $1,34^{\mathrm{NS}}$ & $3,37^{\mathrm{NS}}$ & $1,13^{\mathrm{NS}}$ & $0,93^{\mathrm{NS}}$ & $1,11^{\mathrm{NS}}$ & $1,04^{\mathrm{NS}}$ & $1,79^{\mathrm{NS}}$ \\
\hline C. V. $(\%)$ & 11,21 & 4,80 & 6,43 & 4,89 & 3,71 & 3,75 & 7,27 & 16,84 & 7,83 & 6,01 & 3,78 \\
\hline $\operatorname{DMS}(5 \%)$ & 1,74 & 0,61 & 0,77 & 0,43 & 0,93 & 0,53 & 0,71 & 1,83 & 1,50 & 1,72 & 1,13 \\
\hline \multicolumn{12}{|l|}{$\begin{array}{l}\text { Manejo de plantas } \\
\text { daninhas - } M\end{array}$} \\
\hline Test. S/C & $9,29 a$ & $7,31 \mathrm{a}$ & $6,57 a$ & $5,34 a$ & $14,57 \mathrm{a}$ & $7,97 a$ & $5,89 \mathrm{a}$ & $6,56 a$ & $10,34 a$ & $15,80 \mathrm{a}$ & $21,40 a$ \\
\hline Paraquat & $7,52 \mathrm{~b}$ & $5,45 b$ & $4,99 b$ & $3,84 \mathrm{~b}$ & $11,24 b$ & $5,87 \mathrm{~b}$ & $4,08 \mathrm{~b}$ & $4,40 a b$ & $8,35 b$ & $12,48 \mathrm{~b}$ & $16,41 \mathrm{~b}$ \\
\hline Paraq+Diuron & $7,36 \mathrm{~b}$ & $5,46 \mathrm{~b}$ & $5,21 \mathrm{~b}$ & $3,72 \mathrm{~b}$ & $11,17 \mathrm{~b}$ & $6,14 \mathrm{~b}$ & $4,09 \mathrm{~b}$ & $4,04 \mathrm{~b}$ & $8,12 b$ & $12,04 \mathrm{~b}$ & $16,46 \mathrm{~b}$ \\
\hline Glyphosate & $4,45 \mathrm{c}$ & $5,50 \mathrm{~b}$ & $5,36 \mathrm{~b}$ & $3,57 \mathrm{~b}$ & $9,56 \mathrm{c}$ & $6,13 \mathrm{~b}$ & $4,08 \mathrm{~b}$ & $5,04 a b$ & $8,52 \mathrm{~b}$ & $12,43 b$ & $15,66 b$ \\
\hline F & $46,83^{* *}$ & $14,38^{* *}$ & $5,21^{* *}$ & $23,71^{* *}$ & $70,87^{* *}$ & $23,39^{* *}$ & $5,80^{* *}$ & $3,67^{* *}$ & $13,92^{* *}$ & $19,37 * *$ & $82,41^{* *}$ \\
\hline C.V. (\%) & 14,18 & 14,19 & 19,45 & 14,21 & 7,43 & 10,66 & 28,61 & 40,12 & 10,69 & 10,46 & 5,75 \\
\hline $\operatorname{DMS}(5 \%)$ & 1,13 & 0,94 & 1,20 & 0,65 & 1,50 & 0,77 & 1,45 & 2,24 & 1.05 & 1,54 & 1,12 \\
\hline Interação PxM (F) & $0,10^{\mathrm{NS}}$ & $0,19^{\mathrm{NS}}$ & $0,90^{\mathrm{NS}}$ & $1,13^{\mathrm{NS}}$ & $0,16^{\mathrm{NS}}$ & $0,24^{\mathrm{NS}}$ & $0,14^{\mathrm{NS}}$ & $0,11^{\mathrm{NS}}$ & $0,34^{\mathrm{NS}}$ & $1,14^{\mathrm{NS}}$ & $1,19^{\mathrm{NS}}$ \\
\hline
\end{tabular}

* F significativo a $5 \%$ de probabilidade

** F significativo a $1 \%$ de probabilidade

NS F não significativo

(1) Dados transformados em $\sqrt{x+0,5}$

(2) Médias seguidas pela mesma letra não diferem entre si ao nível de $5 \%$ de probabilidade pelo teste de Tukey 
Os resultados contidos na Tabela 15 mostram que não houve diferença significativa no peso da materia seca para as infestantes analisadas individualmente. Conforme aconteceu para densidade, na totalização de plantas daninhas $G+A$ resultou estatísticamente em menor acúmulo de matéria seca que $\mathrm{Gr}$, enquanto Ar não diferiu de G + A e Gr. SEGUY et al (1984) demonstram que a aração profunda, após a trituração e pré-incorporação com grade aradora dos restos vegetais, permite colocar a maioria das sementes das invasoras a cerca de 30,0 cm de profundidade, dificultando a sua germinação e favorecendo o seu apodrecimento. KLUTHCOUSKI et al (1987) e ANTUNIASSI (1991) também obtiveram menor acúmulo de matéria seca das plantas daninhas, em arroz e milho respectivamente, com preparo de solo com aração profunda, comparando com grade aradora.

Avaliando a infestação das plantas daninhas em função do periodo transcorrido desde a instalação dos tratamentos de preparo do solo, verificou-se que com o passar do tempo as diferenças entre esses tratamentos foram se tornando menos acentuadas, o que está bem ilustrado na Figura 1, que mostra o fator densidade, e na Figura 2 , que visualiza o peso da biomassa seca, cuja exceção é a $I$. hirsuta, que mostrou maior diferenciação no acúmulo de biomassa seca entre os tratamentos na última avaliação do que nas anteriores.

Esses resultados podem ser explicados pela influência que o preparo do solo exerce nas primeiras emergências das plantas daninhas, que normalmente terminam próximo à superficie do solo, onde os preparos que deixam seus propágulos reprodutivos nessas camadas de solo são os que promovem maior potencial de 
D. horizontalis

C. oeninatus

B. plantaginea

o. monocot.
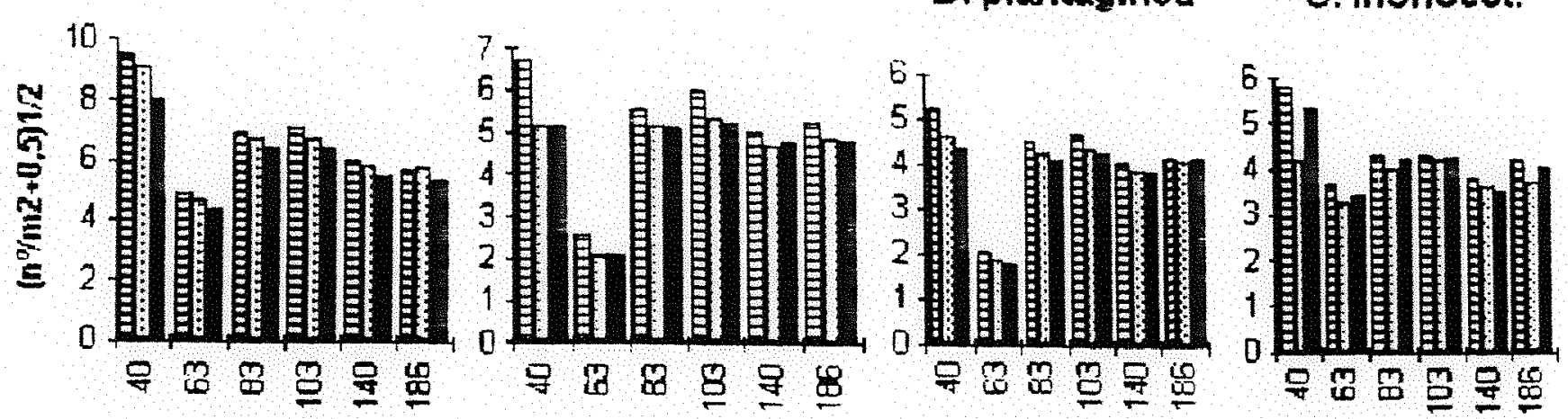

D.A.P.

1. hirsuta

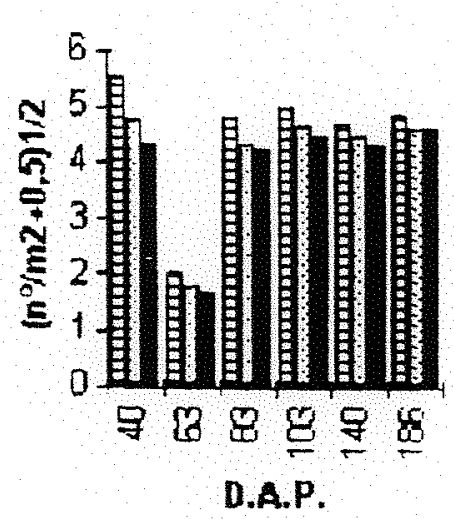

A. hispidum

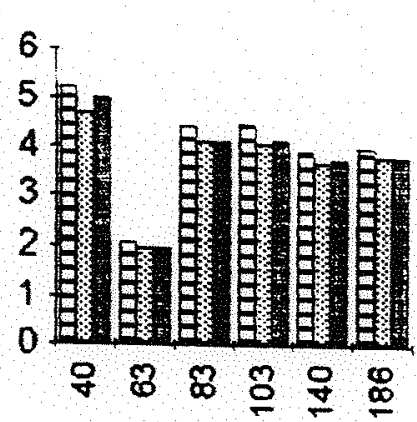

B. momb.

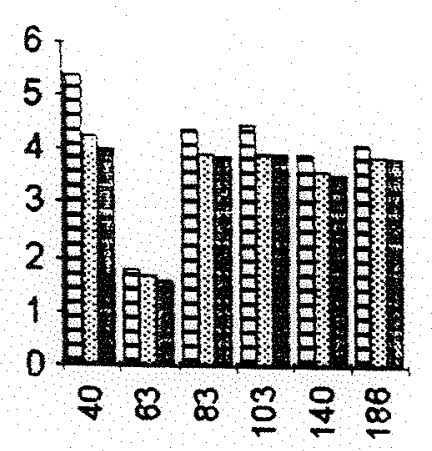

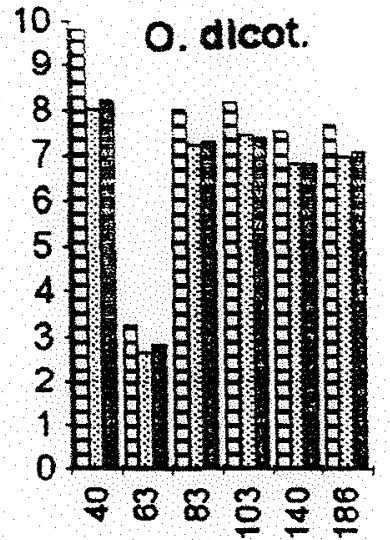

T. monocot

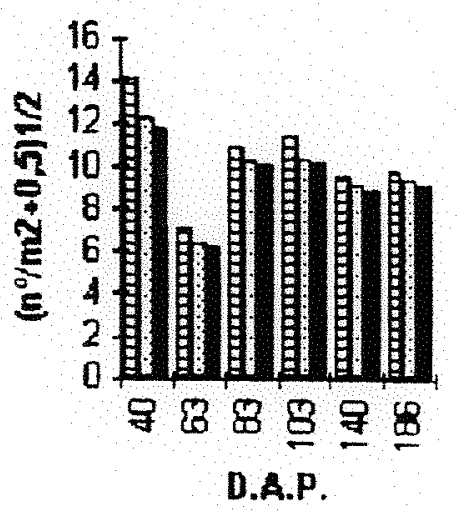

T. dicot.

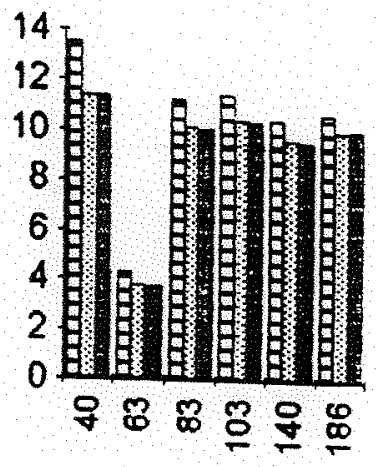

T. de Plantas Daninhas

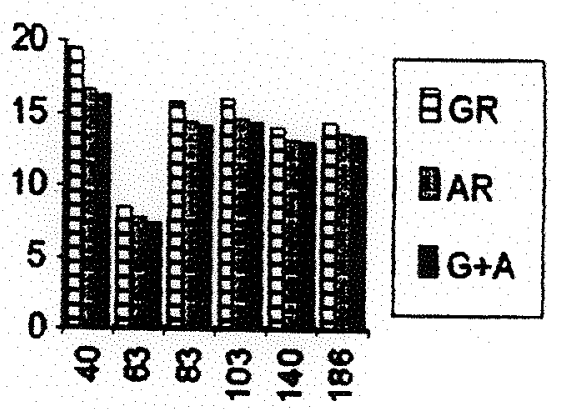

Figura I - Representação da densidade média $\left[\left(\mathrm{n}^{\circ} / \mathrm{m}^{2}+0,5\right)^{1 / 2}\right]$ das espécies infestantes da cultura do algodoeiro, em função de diferentes sistemas antecipado de preparo do solo, nas avaliações aos 40,63,83, 103, 140 e 186 dias apos o preparo 

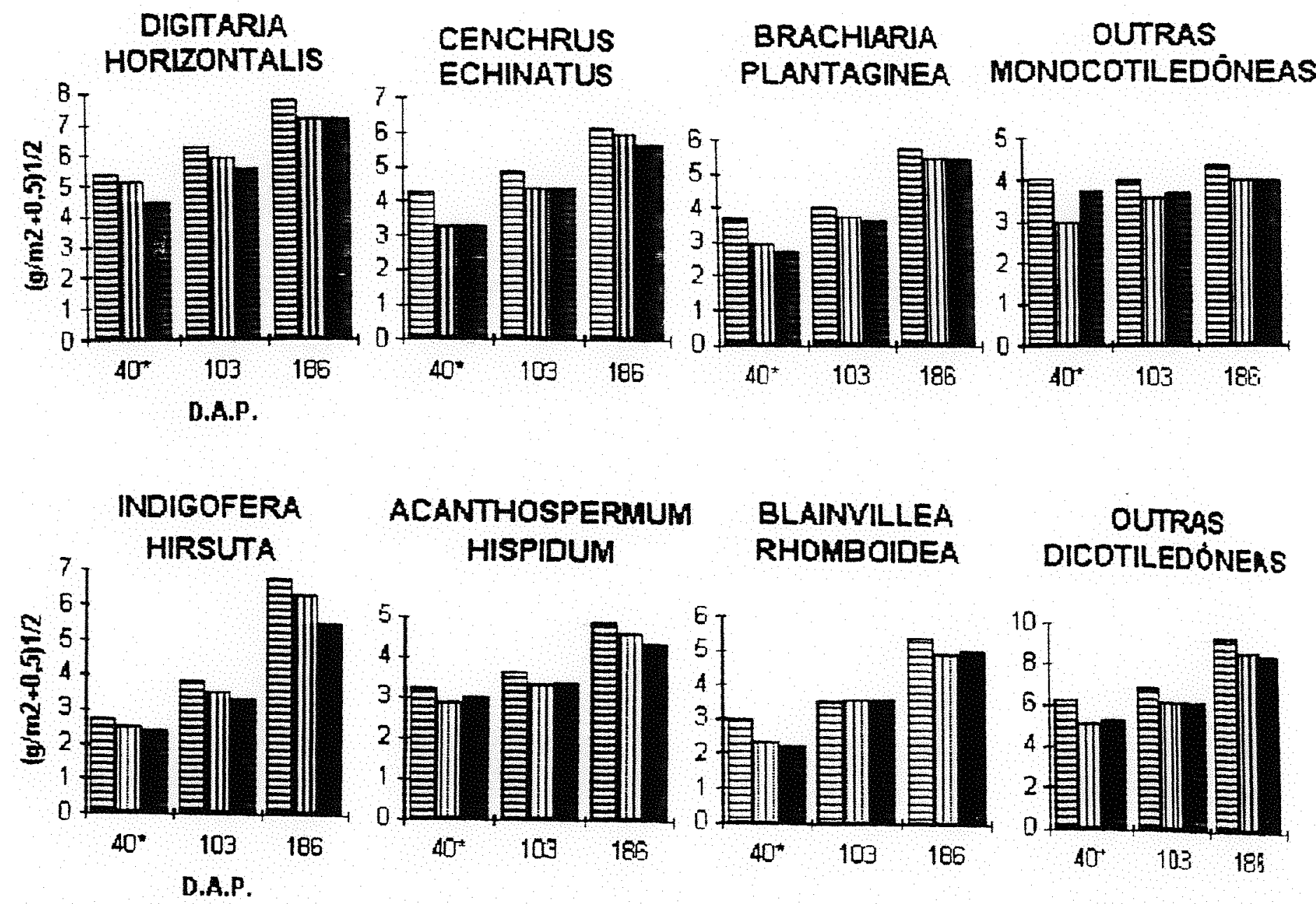

BLAINVILLEA RHOMBOIDEA
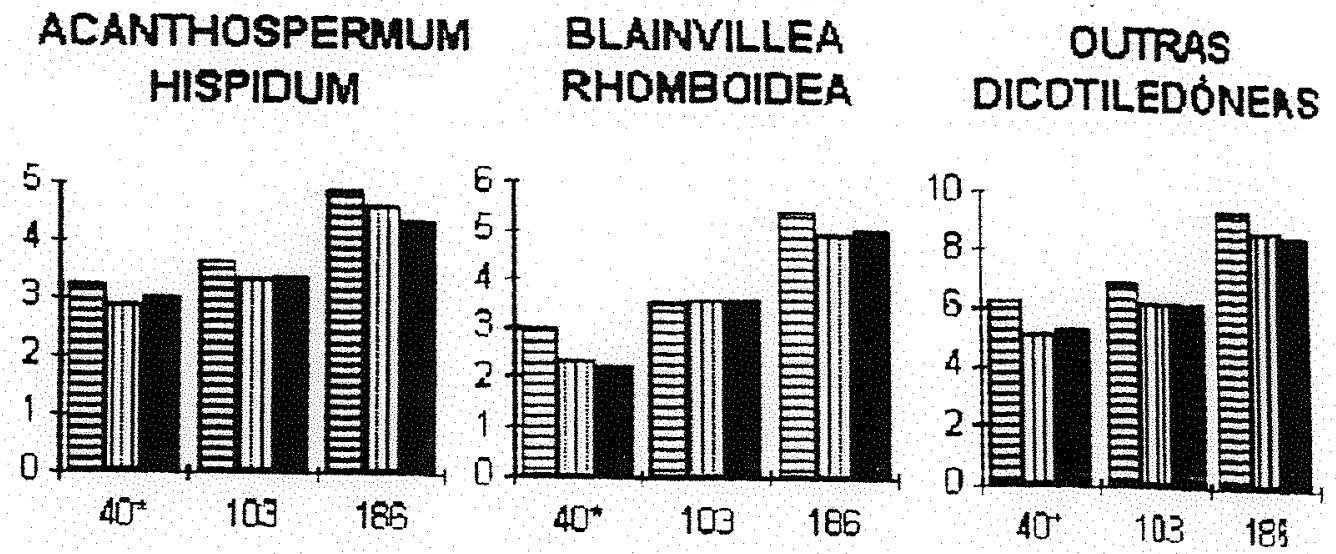

TOTAL DE MONOCOTILEDÓNEAS DICOTILEDÓNEAS

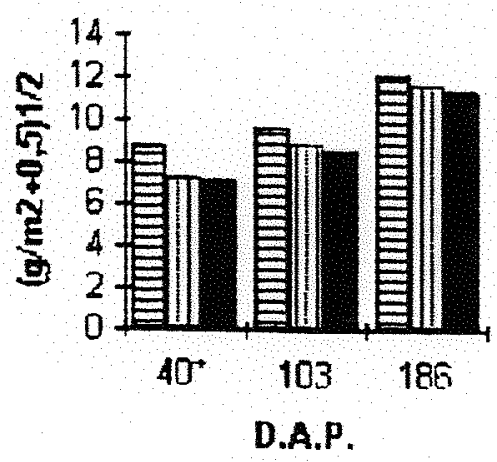

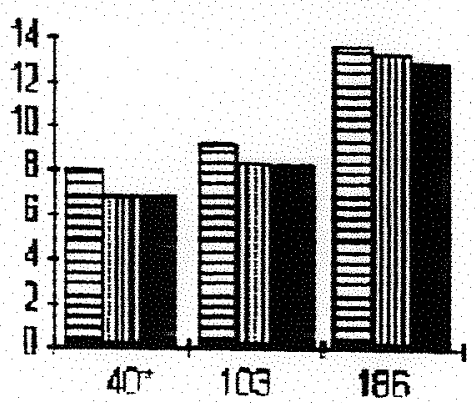

186
TOTAL DE PLANTAS DANINHAS

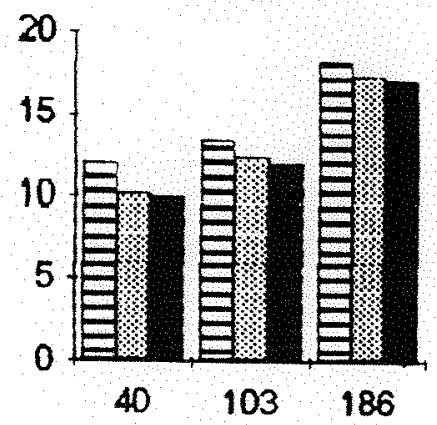

GGR

GAR

G+A

Figura 2 - Representação do peso da biomassa seca $\left[\left(\mathrm{g} / \mathrm{m}^{2}+0,5\right)^{1.2}\right]$ das espécies infestantantes da cultura do algodoeiro, em função de diferentes sistemas antecipado de preparo do solo, nas avaliações aos 40,103 e 186 dias após o preparo 
infestação, como foi mostrado por SEGUY et al (1984); TANG \& ANG (1986) e BUHLER \& MESTER (1991). No entanto essa influência diminui com o transcorrer do tempo, e de acordo com a inibição imposta pela comunidade florística e a composição do banco de sementes do solo, as gerações posteriores de infestantes podem tender a minimizar as diferenças na infestação, tanto em densidade quanto em acúmulo de biomassa seca, como foi o caso desse experimento e o de ANTUNIASSI (1991)

As figuras 3 e 4 representam a comparação da Test s/c com a média os tratamentos de herbicidas de manejo, para os fatores densidade e peso de matéria seca respectivamente. Os resultados mostram que a reinfestação dos tratamentos com herbicidas não alcançou os índices atingidos na infestação obtida pelo tratamento sem controle das plantas daninhas, mostrando que o potencial de desenvolvimento das primeiras gerações germinadas de infestantes foi maior que as posteriores, sendo que na reinfestação obteve-se também uma menor oscilação na diferença entre os tratamentos em relação os periodos de avaliação. Resultados semelhantes foram obtidos por KLUTHCOUSKI et al (1987), comparando quatro preparos de solo para a cultura do arroz, com e sem controle químico da infestação inicial de plantas daninhas

Na figura 5 são apresentados os dados referentes à densidade relativa das plantas daninhas, sendo mostradas individualmente as três principais espécies de monocotiledôneas, atingindo aos 63 dias após o preparo (DAP) o pico de $61,66 \%$. A partir da avaliação aos 83 DAP, houve uma tendência de estabilização entre as classes das plantas daninhas, atingindo na colheita do algodoeiro a densidade relativa de $54,52 \%$ para as dicotiledôneas e $45,48 \%$ para as monocotiledôneas. 


\section{Densidade: TEST SIC $\times \bar{X}$ HERBICIDA}

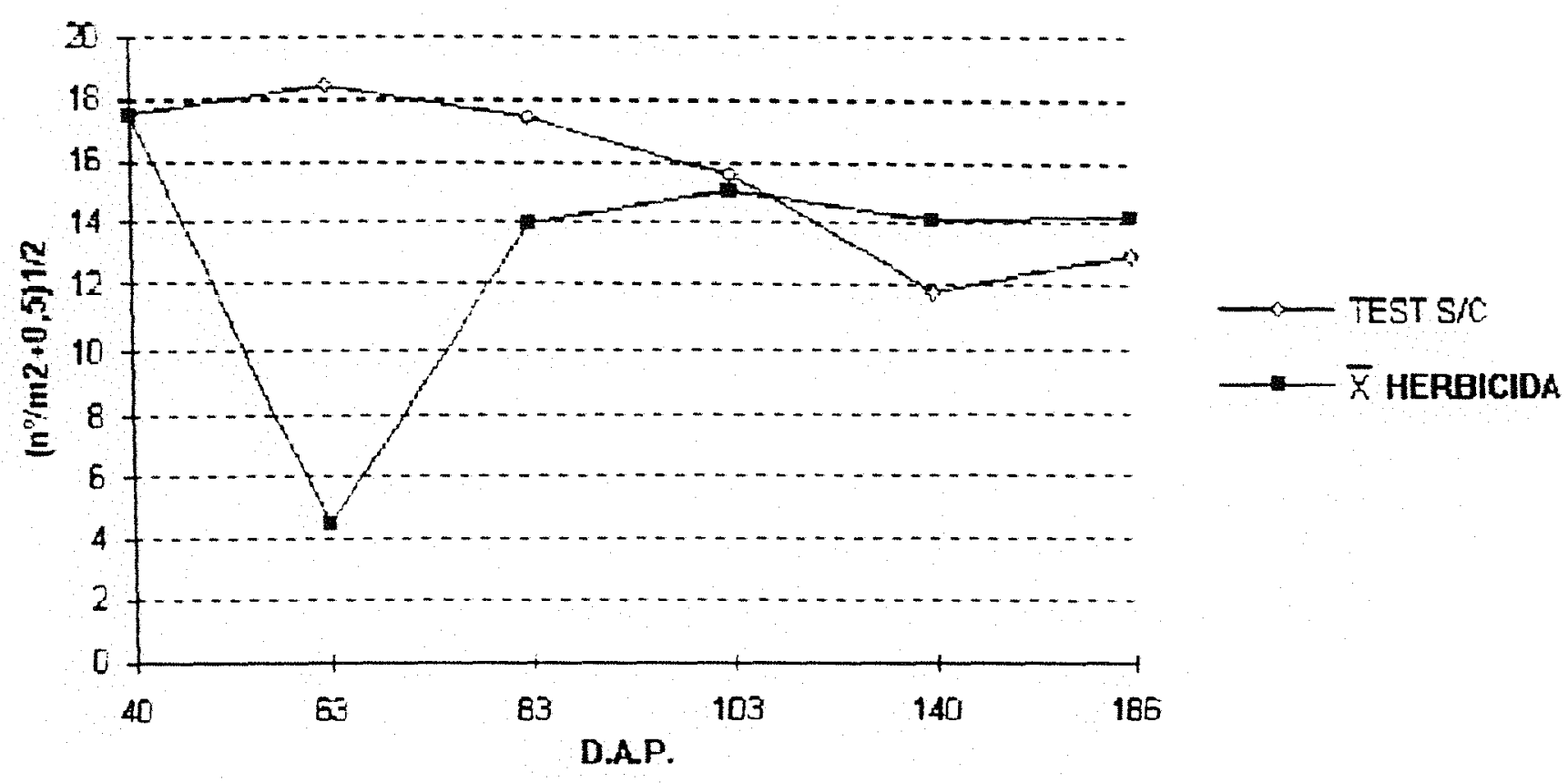

Figura 3 - Densidade $\left[\left(\mathrm{n}^{\circ} / \mathrm{m}^{2}+0,5\right)^{1 / 2}\right]$ das espécies infestantes da cultura do algodoeiro, no tratamento sem controle das plantas daninhas (Test $\mathrm{s} / \mathrm{c}$ ) e na média dos tratamentos de herbicidas de manejo ( $\overline{\mathrm{X}}$ herbicida), nas avaliações aos 40,63,83,103,140 e 186 dias apos o preparo do solo 
Biomassa Seca: TEST SIC x $\bar{X}$ HERBICIDA

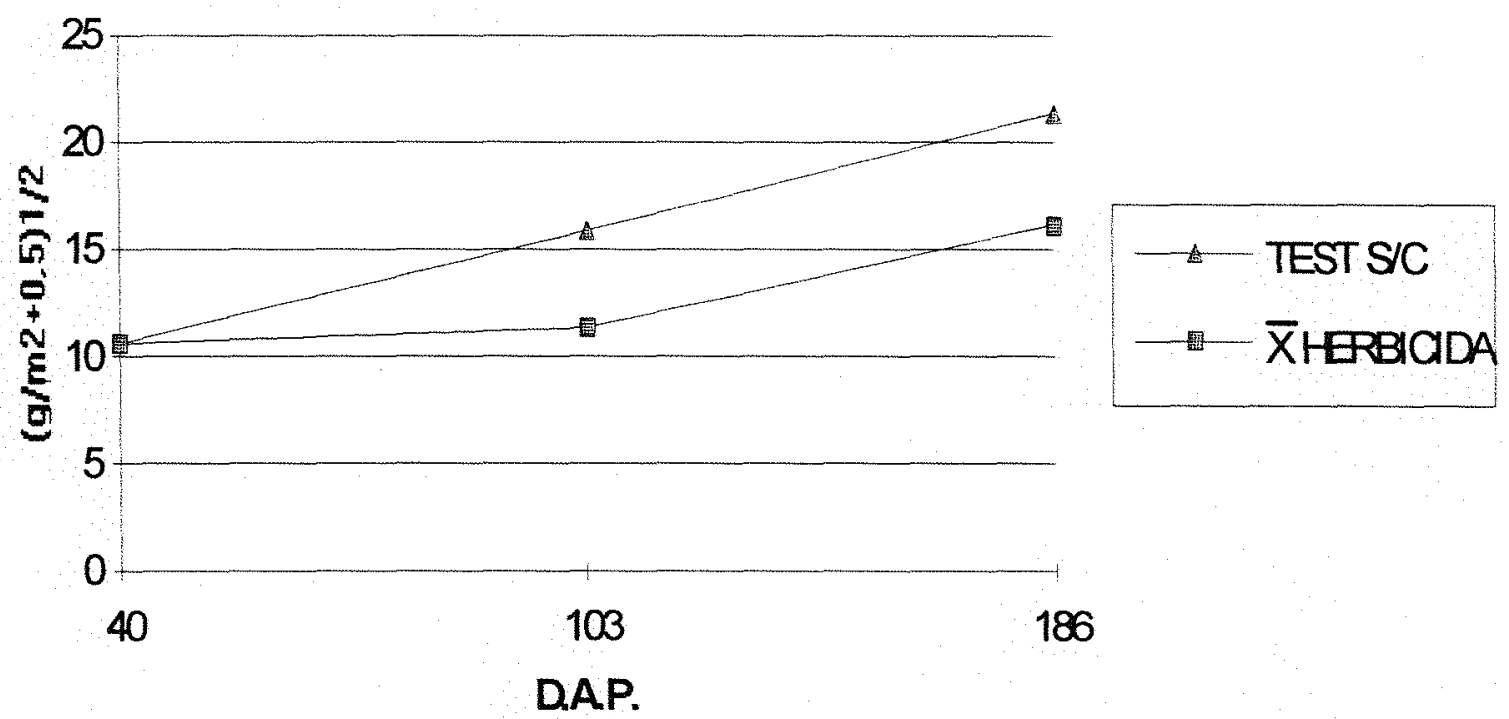

Figura 4 - Peso da biomassa seca $\left[\left(\mathrm{g} / \mathrm{m}^{2}+0,5\right)^{1 / 2}\right]$ das espécies infestantes da cultura do algodoeiro, no tratamento sem controle das plantas daninhas (Test $\mathrm{s} / \mathrm{c}$ ) e na média dos tratamentos de herbicidas de manejo $(\overline{\mathrm{X}}$ herbicida), nas avaliações aos 40,103 e 186 dias após o preparo do solo. 
Na primeira avaliação, anterior ao preparo do solo, as dicotiledôneas predominavam na área com $74,88 \%$, contra apenas $25,12 \%$ das monocotiledôneas. Após a movimentação, a predominância passou a ser das monocotiledôneas, atingindo aos 63 dias após o preparo (DAP) o pico de $61,66 \%$. A partir da avaliação aos 83 DAP, houve uma tendência de estabilização entre as classes das plantas daninhas, atingindo na colheita do algodoeiro a densidade relativa de $54,52 \%$ para as dicotiledôneas e $45,48 \%$ para as monocotiledôneas

Dentre as monocotiledôneas nota-se que o baixo controle de $D$. horizontalis pelo $\mathrm{P}+\mathrm{D}$ e Par, fez com que essa espécie tivesse grande predominância a partir dos 63 DAP, o que também ocorreu com "outras monocotiledôneas", devido ao baixo controle exercido pelos herbicidas sobre $C$. rotundus. Nas avaliações posteriores houve uma regressão na densidade relativa desses dois grupos de espécies, sendo que a partir dos 103 DAP a composição dessa classe se estabilizou.

Uma característica marcante observada nas dicotiledôneas foi a diversidade da sua população, pois enquanto o total de monocotiledôneas era formado por sete espécies, as dicotiledôneas foram compostas por dezesseis espécies, fazendo com que o agrupamento de "outras dicotiledôneas" tivesse sempre densidade relativa superior aos demais nessa classe. Mesmo tendo uma queda abrupta aos 63 DAP, em virtude do controle químico, I. hirsuta, B. rhomboidea e A. hispidum, mantiveram geralmente constante seus índices de densidade relativa, atingindo na última avaliação $11,35 \%, 8,02 \%$ e $7,71 \%$ respectivamente 


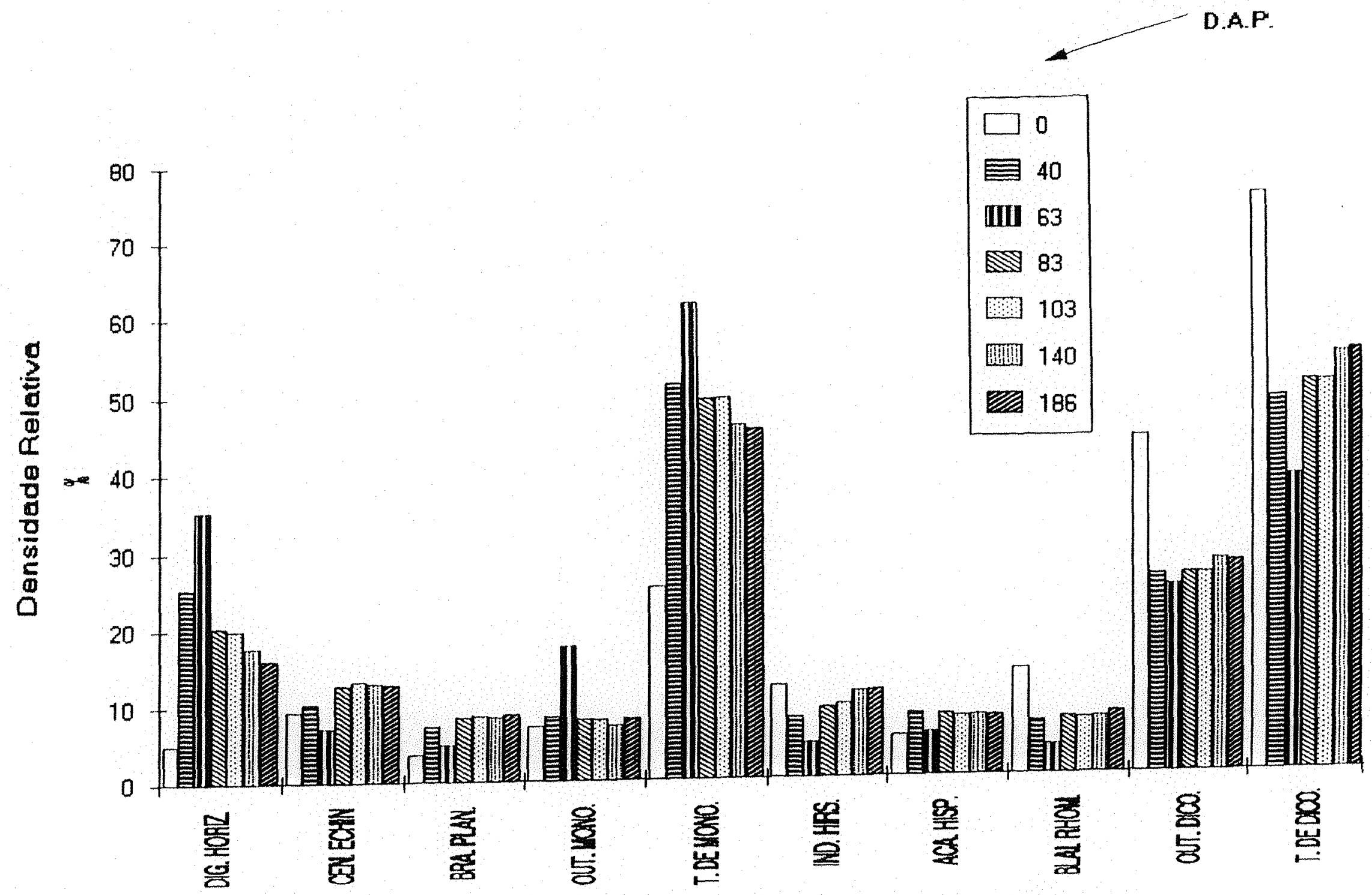

FIGURA 5. Representação da densidade relativa (\%) das espécies infestantes da cultura do algodoeiro, nas avaliações aos

$0,40,63,83,103,140$ e 186 dias após o preparo do solo. 


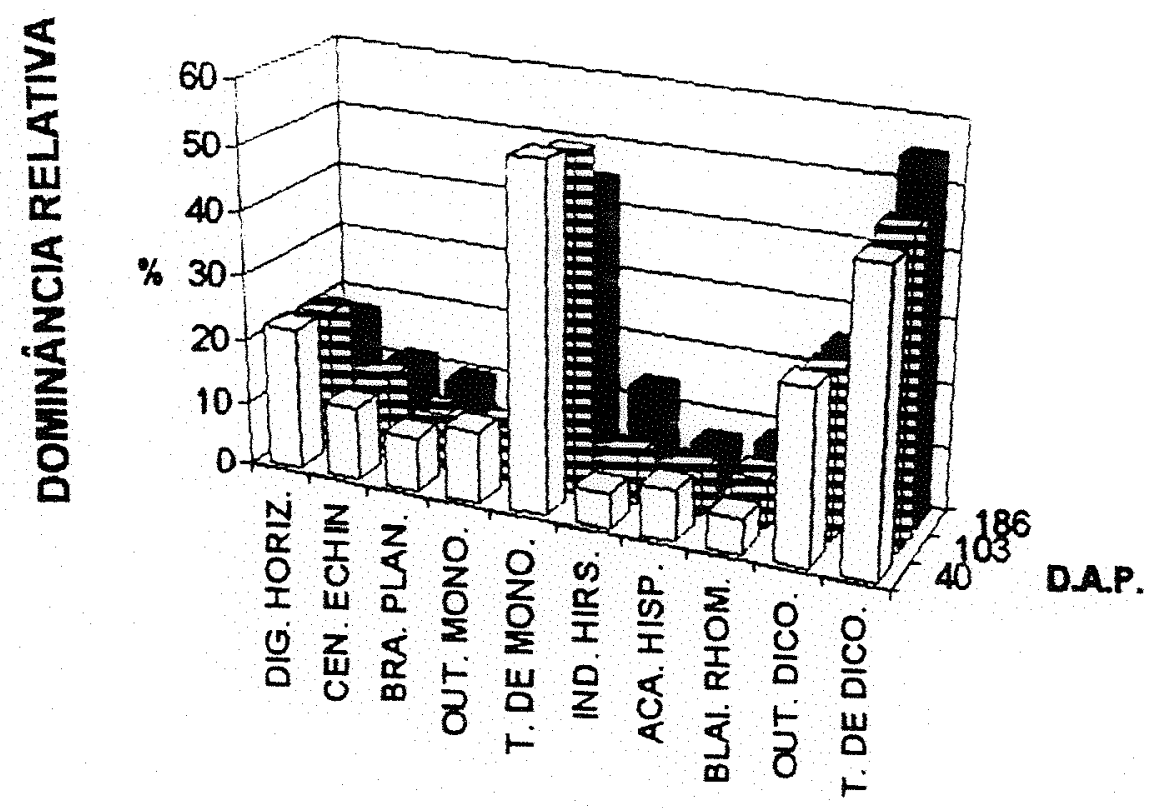

FIGURA 6 - Representaçào da dominância relativa (\%) das espécies infestantes da cultura do algodoeiro, nas avaliações aos 40,103 e 186 dias após o preparo do solo 
Na Figura 6 são apresentados os dados referentes à dominância relativa das plantas daninhas, sendo também mostradas individualmente as três principais espécies de cada classe presente no experimento, sendo as demais espécies englobadas no item "outras" monocotiledôneas ou dicotiledôneas.

Os dados mostram a íntima relação existente entre dominância e densidade relativas, pois a tendência dos resultados foi muito semelhante entre esses dois fatores de análise da infestação de plantas daninhas. Verificou-se contudo, que em função de maior acúmulo de biomassa seca por parte de algumas espécies, estas apresentaram índices proporcionalmente maiores que os de densidade relativa, como foi o caso de D. horizontalis, B. plantaginea e I. hirsuta.

\subsection{Comportamento da cultura do algodoeiro}

\subsubsection{Características fitotécnicas}

$\mathrm{Na}$ Tabela 16 são apresentados os resultados referentes as características fitotécnicas da cultura nas avaliaçõas a nível de campo. Observa-se que não houve significância entre os tratamentos de preparo do solo e também na interação desses tratamentos com os de manejo das plantas daninhas.

O tratamento com controle das plantas daninhas durante todo 0 experimento (Test $\mathrm{c} / \mathrm{c}$ ) foi o que apresentou a maior média de altura da cultura, seguido de Gly que superou P + D e Par, que por sua vez foram superiores a Test s/c. 
TABELA 16 - Caracteristicas fitotecaicas do algodoeiro em semeadura direta. na avaliação a nivel de campo, em de função de diferentes preparos antecipado do solo e manejo das plantas daninhas.

\begin{tabular}{|c|c|c|c|c|c|c|}
\hline $\begin{array}{l}\text { Preparo do } \\
\text { solo }\end{array}$ & $\begin{array}{l}\text { Altura } \\
(\mathrm{cm})\end{array}$ & $\begin{array}{l}\text { Diàmetro do } \\
\text { caule } \\
(\mathrm{mm})\end{array}$ & $\begin{array}{l}\mathrm{N}^{\circ} \text { de ramos } \\
\text { produtivos }\end{array}$ & $\begin{array}{l}\mathrm{N}^{\circ} \text { de capulhos } \\
\text { por planta }\end{array}$ & $\begin{array}{l}\text { Ocorrência do } \\
1 \text { capulho } \\
\text { (dias) }\end{array}$ & $\begin{array}{l}\text { Altura de } \\
\text { inserção do } 1^{\circ} \\
\text { ramo produtivo } \\
\text { (cm) }\end{array}$ \\
\hline Grade & $87.25 \mathrm{a}$ & $9,84 \mathrm{a}$ & $9,37 \mathrm{a}$ & $9,32 \mathrm{a}$ & $118,85 \mathrm{a}$ & $27,30 \mathrm{a}$ \\
\hline Arado & $87,76 a$ & $10.44 \mathrm{a}$ & $9.56 \mathrm{a}$ & $9.56 \mathrm{a}$ & $118.76 \mathrm{a}$ & 27.49 \\
\hline Grade + Arado & $88,01 \mathrm{a}$ & $10,48 \mathrm{a}$ & $9,60 \mathrm{a}$ & $9,61 \mathrm{a}$ & $118,68 a$ & $27,36 a$ \\
\hline $\mathrm{F}$ & $5,10^{\mathrm{ns}}$ & $5.03^{\mathrm{ns}}$ & $4,30^{\mathrm{ns}}$ & $4,08^{n s}$ & $2,71^{\mathrm{ns}}$ & $0,32^{\mathrm{ns}}$ \\
\hline $\mathrm{CV}(\%)$ & 3,28 & 6,79 & 3,29 & 1,85 & 1,72 & 2,11 \\
\hline DMS $(5 \%)$ & 0,77 & 0,66 & 0,26 & 0,32 & 0.27 & 1,26 \\
\hline Manejo P.D & & & & & & \\
\hline Test $\mathrm{c} / \mathrm{c}$ & $115,27 \mathrm{a}$ & $13,53 \mathrm{a}$ & $13.47 \mathrm{a}$ & $13,45 \mathrm{a}$ & $118,51 \mathrm{a}$ & $22,00 \mathrm{~d}$ \\
\hline Glyphosate & $94,14 b$ & $11,64 b$ & $10,97 \mathrm{~b}$ & $11,30 \mathrm{~b}$ & $118,60 \mathrm{ab}$ & $25,73 c$ \\
\hline Paraquat + Diuron & $87,47 \mathrm{c}$ & $10,98 \mathrm{c}$ & $10,24 \mathrm{c}$ & $10,28 \mathrm{c}$ & $118.68 \mathrm{ab}$ & $27.47 \mathrm{~b}$ \\
\hline Paraquat & $87,46 c$ & $10,84 \mathrm{c}$ & $10,15 c$ & $10,17 \mathrm{c}$ & $118,73 \mathrm{ab}$ & $27,56 b$ \\
\hline Test $\mathrm{s} / \mathrm{c}$ & $50,07 \mathrm{~d}$ & $4,66 \mathrm{~d}$ & $2,21 \mathrm{~d}$ & $2,29 \mathrm{~d}$ & $118,89 b$ & $34,60 \mathrm{a}$ \\
\hline$F$ & $7.789 .15^{* *}$ & $1.327,50^{* *}$ & $2.510,99 * *$ & $1.634 .54^{* *}$ & $9.63 *$ & $138,64^{* *}$ \\
\hline $\operatorname{cv}(\%)$ & 3,06 & 3,05 & 3,11 & 3,82 & 2,71 & 4,89 \\
\hline DMS $(5 \%)$ & 1,08 & 0,36 & 0,34 & 0,42 & 0,29 & 1.57 \\
\hline Interação $\mathrm{P} \times \mathrm{M}(\mathrm{F})$ & $2,35^{\mathrm{ns}}$ & $2.18^{\mathrm{ns}}$ & $2.16^{\mathrm{ns}}$ & $0.70^{\mathrm{ns}}$ & $0,24^{\mathrm{ns}}$ & $1,49^{\text {ns }}$ \\
\hline
\end{tabular}

* F significativo a $5 \%$

** F significativo a $1 \%$

ns $\mathrm{F}$ não significativo

Médias seguidas para mesma letra não diferem entre si pelo teste de Tukey, ao nivel da $5 \%$ de probabilidade. 
Estes resultados comprovam que quanto maior o potencial competitivo da comunidade infestante, principalmente por água, luz e nutrientes, maior a redução do porte dos algodoeiros em altura, que neste caso chegou a $56,5 \%$.

GREEN et al. (1988) encontraram redução máxima de $25,0 \%$ na altura da cultura competindo exclusivamente com Solanum elaegnifolium, enquanto BROWN \& WHITWELL (1985b) chegaram a diminuições de 6,0 a $23,0 \mathrm{~cm}$ na altura dos algodoeiros em competição com Cynodon dactylon. HIGGINS et al (1985) afirmam que para cada semana de competição de Cassia ocidentalis com a cultura do algodoeiro, esta teve redução entre 1,0 a $1,5 \mathrm{~cm}$ na sua altura

Analisando os dados de diâmetro do caule, número de ramos produtivos e número de capulhos por planta, verifica-se que houve um comportamento semelhante entre os tratamentos de manejo de plantas daninhas em relação as diferenças significativas, onde estatisticamente Test c/c obteve melhores resultados que Gly, que foi superior a $\mathrm{P}+\mathrm{D}$ e Par, que superaram a Test s/c.

Esses resultados são também idênticos aos obtidos para altura das plantas da cultura, valendo a mesma justificativa exposta na análise daquele parâmetro, isto é, uma comunidade infestante com maior poder de competição, principalmente por água, nutrientes e luz, resulta em menor desenvolvimento do algodoeiro de uma maneira geral, que refletiu nesse caso, em um menor diâmetro de caule, menor número de ramos produtivos e também em um menor número de capulhos por planta.

Na comparação entre o maior e o menor diâmetro de caule obtidos, que foram os da Test $\mathrm{c} / \mathrm{c}$ e o da Test $\mathrm{s} / \mathrm{c}$ respectivamente, observa-se que a redução encontrada foi de $65,56 \%$. BELTRÃO et al (1983) trabalhando com competição de plantas daninhas em algodoeiro herbáceo encontraram reduções no diâmetro do caule 
da cultura, totalmente infestada, da ordem de $48,06 \%$. Resultados semelhantes foram obtidos por ROBINSON (1976) e GUERRA FILHO (1980).

Os dados sobre o número de ramos produtivos mostram uma redução em até $83,59 \%$ entre os resultados obtidos. BELLETTINI (1988) e BANCI (1992) estudando os efeitos de diversos espaçamentos e populações de plantas para a cultura do algodoeiro, concluiram que quanto menor o espaçamento e maior a população de plantas, menor é o número de ramos produtivos produzidos por planta, sendo consequência básica da competição intraespecífica da cultura. No caso deste trabalho, a competição interespecífica foi a principal responsável pela diminuição no número de ramos produtivos por planta.

Com relação ao número de capulhos por planta, também verificou-se uma drástica redução, de $82,97 \%$, comparando-se o maior (Test c/c) e o menor (Test s/c) valor obtido. EL-SHAER et al. (1985) testando populações de $83.000,166.000$ e 250.000 plantas/ha e controle químico e manual das plantas daninhas, obtiveram um maior número de capulhos no menor stand e no melhor controle de plantas daninhas, que foi o manual GUERRA FILHO (1980) e GREEN et al (1988) também encontraram maior número de capulhos por planta em tratamentos com menor competição com plantas daninhas.

Ainda analisando os dados da Tabela 16 , nota-se que o resultado obtido para altura de inserção do primeiro ramo produtivo é o inverso do obtido para número de ramos produtivos, isto é, quanto maior foi o potencial de competição das plantas daninhas do tratamento, maior foi a altura de inserção do primeiro ramo produtivo. Em estudo específico dessa característica, YAMAOKA et al (1982) trabalhando com competição intraespecífica da cultura dimensionada em várias 
populações de plantas, concluíram que à medida que se aumenta a população por unidade de área, e por conseguinte a competição, ocorrem aumentos significativos na altura de inserção do primeiro ramo produtivo LAMAS (1988), BELLETTINI (1988) e BANCI (1992) chegaram a mesma conclusão. BAKER (1976) explica que a competição por luz é a principal causa para tais resultados, onde principalmente o terço inferior dos algodoeiros recebendo pouca intensidade luminosa, tende a produzir um menor número de estruturas frutíferas.

Como os capulhos inicialmente formados pelos algodoeiros encontramse nos ramos produtivos mais baixos, houve a tendência de um período mais curto para o aparecimento do primeiro capulho nos tratamentos com menor altura de inserção dos ramos produtivos, que foram aqueles sujeitos a menor competição com as plantas daninhas. BELLETTINI (1988) e BANCI (1992) confirmam essa explicação. No entanto, as diferenças encontradas foram muito pequenas, sendo que apenas Test $\mathrm{c} / \mathrm{c}$ e Test $\mathrm{s} / \mathrm{c}$ diferiram significativamente entre si Os períodos encontrados no aparecimento desse primeiro capulho, ao redor dos 118 dias, está de acordo com o informado por GRIDI-PAPP (1992) e MARUR (1993).

$\mathrm{Na}$ Tabela 17 são apresentados os resultados referentes as características fitotécnicas da cultura nas avaliações a nível de laboratório. Observa-se que, também para os parâmetros dessa tabela, não houve significância para os tratamentos de preparo de solo e para a interação desses tratamentos com os de manejo das plantas daninhas

A precocidade representa a porcentagem da produção obtida na primeira colheita em relação ao total produzido pela cultura. Os dados mostram que 
TABELA 17 - Caracteristicas fitotecnicas do algodoeiro em semeadura direta. naa avaliação a nivel de laboratório, em função de diferentes preparos antecipado do solo e manejo das plantas.

\begin{tabular}{|c|c|c|c|c|}
\hline Preparo do solo & $\begin{array}{c}\text { Precocidade } \\
(\%)\end{array}$ & $\begin{array}{c}\text { Porcentagem de } \\
\text { fibras }\end{array}$ & $\begin{array}{c}\text { Peso de capulho } \\
\text { (g) }\end{array}$ & $\begin{array}{l}\text { Peso de } 100 \\
\text { sementes }(\mathrm{g})\end{array}$ \\
\hline Grade & $64,88 \mathrm{a}$ & $37.62 \mathrm{a}$ & $5,86 \mathrm{a}$ & $12.46 \mathrm{a}$ \\
\hline Arado & $64.91 a$ & $37,63 a$ & $5,96 \mathrm{a}$ & $12,56 a$ \\
\hline Grade + Arado & $64.96 \mathrm{a}$ & $37,78 \mathrm{a}$ & $6,00 \mathrm{a}$ & $12.62 \mathrm{a}$ \\
\hline $\mathbf{F}$ & $0,38^{\mathrm{ns}}$ & $1,27^{\mathrm{ns}}$ & $1,12^{\mathrm{ns}}$ & $1.59^{\mathrm{ns}}$ \\
\hline $\operatorname{CV}(\%)$ & 1,20 & 1,42 & 2,39 & 1,01 \\
\hline $\operatorname{DMS}(5 \%)$ & 0,29 & 0,34 & 0,30 & 0,27 \\
\hline
\end{tabular}

Maneio P.D.

\begin{tabular}{|c|c|c|c|c|}
\hline Test $\mathrm{c} / \mathrm{c}$ & $66,49 a$ & $37,85 \mathrm{a}$ & $7,77 \mathrm{a}$ & $13,71 \mathrm{a}$ \\
\hline Glyphosate & $66,29 \mathrm{a}$ & $37,78 a$ & $6.37 \mathrm{~b}$ & $13,48 \mathrm{ab}$ \\
\hline Paraquat + Diuron & $66,14 a$ & $37,64 a$ & $6.05 \mathrm{~b}$ & $13,37 \mathrm{~b}$ \\
\hline Paraquat & $66,15 \mathrm{a}$ & $37,56 \mathrm{a}$ & $5,99 \mathrm{~b}$ & $13,34 \mathrm{~b}$ \\
\hline Test $\mathrm{s} / \mathrm{c}$ & $59,56 \mathrm{~b}$ & $37,55 \mathrm{a}$ & $3,41 \mathrm{c}$ & $8.82 \mathrm{c}$ \\
\hline $\mathbf{F}$ & $192,71^{* *}$ & $2,61^{\mathrm{ns}}$ & $374,22 * *$ & $625,05^{* *}$ \\
\hline $\mathrm{CV}(\%)$ & 4.15 & 2,67 & 4,77 & 2,25 \\
\hline DMS (5\%) & 0,87 & 0,33 & 0.38 & 0,32 \\
\hline Interação $\mathrm{P} \times \mathrm{M}(\mathrm{F})$ & $0.15^{\mathrm{ns}}$ & $0,80^{\mathrm{nS}}$ & $0,31^{\mathrm{ns}}$ & $0,39^{\text {ns }}$ \\
\hline
\end{tabular}

* F significativo a $5 \%$

** F significativo a $1 \%$

ns F não significativo

Médias seguidas para mesma letra não diferem entre si pelo teste de Tukey. ao nivel de $5 \%$ de probabilidade. 
com excessão da Test $\mathrm{s} / \mathrm{c}$, que obteve resultado significativamente inferior, os demais tratamentos não diferenciaram-se entre si.

Trabalhos de pesquisa que analisam essa característica do algodoeiro, em relação a competição intra a interespecífica, divergem muito em relação as suas conclusões. Alguns como BELTRÃO et al (1983) e BANCI (1992) concordam com os resultados obtidos, enquanto FOWLER \& RAY (1977) constataram que quanto maior a competição, maior a precocidade. BAKER (1976) não encontrou diferença na precocidade, analisando diversos níveis de competição. A diversidade nesses resultados pode ser creditada a variabilidade existente para a escolha da época de realização dessa primeira colheita, onde a antecipação ou atrazo podem influir muito nessa característica da cultura.

Os resultados obtidos para porcentagem de fibras mostram que essa característica não foi influenciada pelos tratamentos estudados, confirmando trabalhos de RUSHING et al (1986), GREEN et al (1988) e LAMAS (1988). Como a obtenção desse dado é feito pela relação entre o peso do algodão em caroço menos o peso das sementes pelo peso do algodão em caroço, expresso em

porcentagem, conclui-se que houve um comportamento proporcionalmente semelhante entre os índices de algodão em caroço e peso das sementes, nos tratamentos estudados.

Com a diminuição do potencial competitivo das infestantes, aumentouse o peso médio de um capulho. Não houve diferença entre os tratamentos com herbicidas, sendo que esses foram estatisticamente inferiores a Test $\mathrm{c} / \mathrm{c}$, mas superaram a Test $\mathrm{s} / \mathrm{c}$. Um maior peso de capulho com menor competição também foi verificado por FOWLER \& RAY (1977), GUERRA FILHO (1980) e EL-SHAER et 
al. (1985). Além da influência direta da competição por água, luz e nutrientes, outro fator que ajudou na diminuição do peso de capulho nos tratamentos mais infestados por plantas daninhas, foi o fato desses possuirem um menor número de capulhos no terço inferior, sendo que esse capulhos possuem, naturalmente, um maior peso, no geral, do que os do terço médio e superiores.

Quanto maior foi o potencial de competição das plantas daninhas menor foi $\mathrm{o}$ peso de 100 sementes obtido, sendo que a Test $\mathrm{c} / \mathrm{c}$ teve resultado semelhante a Gly, mas superior aos demais tratamentos, inclusive $35,66 \%$ maior em relação a Test s/c, que foi o pior de todos os tratamentos, enquanto que não houve diferença significativa entre os que receberam herbicidas de manejo. Também uma maior competição, gerando uma redução na partição de fotoassimilados, explica tais resultados, conforme relatam BROWN \& WHITWELL (1985b), LAMAS (1988) e BANCI (1992).

\subsubsection{Produção de algodão em caroço}

Na Tabela 18 são apresentados os dados referentes a produção de algodão em caroço, em $\mathrm{kg} / \mathrm{ha}$. Verifica-se não haver diferença significativa entre os resultados dos tratamentos de preparo do solo e também na interação desses tratamentos com os de manejo das plantas daninhas. 
TABELA 18 - Produção de algodão em caroço, em $\mathrm{kg} / \mathrm{ha}$, em função de diferentes preparos antecipado do solo e manejo das plantas daninhas.

\begin{tabular}{|c|c|}
\hline Preparo do solo & $\begin{array}{l}\text { Produção } \\
\mathrm{kg} / \mathrm{ha}\end{array}$ \\
\hline Grade & $2.279,09 a$ \\
\hline Arado & $2.341,87 \mathrm{a}$ \\
\hline Grade + Arado & $2.349,40 \mathrm{a}$ \\
\hline$F$ & $2,47^{\mathrm{ns}}$ \\
\hline $\mathrm{CV}(\%)$ & 3,94 \\
\hline DMS $(5 \%)$ & 198,70 \\
\hline \multicolumn{2}{|l|}{ Manejo das P.D. } \\
\hline Test $\mathrm{c} / \mathrm{c}$ & $4.643,38 \mathrm{a}$ \\
\hline Glyphosate & $2.551,49 \mathrm{~b}$ \\
\hline Paraq + Diuron & $2.018,10 \mathrm{c}$ \\
\hline Paraquat & $1.988,03 \mathrm{c}$ \\
\hline Test s/c & $416,25 d$ \\
\hline $\mathrm{F}$ & $148,90 * *$ \\
\hline $\mathrm{CV}(\%)$ & 13,20 \\
\hline $\operatorname{DMS}(5 \%)$ & 359,86 \\
\hline Interação $\mathrm{P}$ x M (F) & $0,20^{\mathrm{ns}}$ \\
\hline $\begin{array}{l}\text { F significativo a } 5 \% \\
\text { F significativo a } 1 \% \\
\text { F não significativo }\end{array}$ & \\
\hline
\end{tabular}

Médias seguidas para mesma letra não diferem entre si pelo teste de Tukey, ao nível da $5 \%$ de probabilidade. 
$\mathrm{Na}$ medida em que aumentou-se o nivel de competição das plantas daninhas com o algodoeiro houve redução na produção de algodão em caroço. Esse resultado de produção confirma claramente a totalização dos resultados das características fitotécnicas analisadas no item 4.2.1. , que mostraram a mesma tendência. Observa-se por isso que o tratamento com controle total das plantas daninhas (Test c/c) apresentou a maior produção de $4.643,38 \mathrm{~kg} / \mathrm{ha}$, diferenciando-se significativamente dos demais, enquanto que a Test s/c obteve apenas $416,25 \mathrm{~kg} / \mathrm{ha}$, mostrando uma redução de $91,03 \%$. Esse resultado de diminuição da produção devido a competição com plantas daninhas aproxima-se bastante dos obtidos por BLANCO \& OLIVEIRA (1976); LACA-BUENDIA et al. (1979); MORAES et al. (1982); CIA et al (1978) e AZEVEDO et al. (1978).

Entre os tratamentos de herbicidas de manejo, verifica-se que Gly foi significativamente superior a $P+D$ e Par, que por sua vez não diferenciaram-se entre si Explica-se tal resultado pelo nível de infestação encontrado nas avaliações realizadas principalmente até os $61 \mathrm{DAA}$, que corresponde a 47 dias após a germinação da cultura, onde Gly apresentou infestações estatisticamente inferiores a P + D e Par, principalmente em função do melhor controle de $D$. horizontalis, sendo que essas infestações durante esse período influenciou decisivamente na diferença de produção de algodão em caroço entre esses tratamentos. Essa constatação é comprovada por BLANCO \& OLIVEIRA (1976); BLANCO et al. (1991); CIA et al. (1978) e IAPAR (1978), que afirmam ser o periodo da emergência até os 50 dias, o mais sensível a nível de competição, para a cultura do algodoeiro. 


\subsubsection{Características tecnológicas das fibras}

Na Tabela 19 são apresentados os dados referentes as características tecnológicas das fibras do algodoeiro, características estas de suma importância na avaliação da cultura, pois determinam a qualidade e valor industrial do produto obtido. Verifica-se que não houve diferença significativa entre os resultados dos tratamentos de preparo de solo e também na interação desses tratamentos com os de manejo das plantas daninhas.

Os tratamentos de manejo das plantas daninhas, que espelham o nível de competição entre as infestantes e a cultura durante o experimento, revelam que essa competição influiu na composição dos caracteres tecnológicos das fibras do algodoeiro. GRIDI-PAPP et al. (1992) afirmam que a competição exercida pelas plantas daninhas com o algodoeiro impede a boa formação da fibra, com prejuízos na sua finura, maturidade, uniformidade e tenacidade. Esses mesmos autores são os responsáveis pelas descrições de funções e importância de cada característica de fibra analisada nesse trabalho.

O comprimento da fibra influi no título, aparência e resistência do fio produzido, determinando os ajustamentos e detalhes de construções das máquinas utilizadas na fiação. Os resultados mostram que a Test c/c, com menor infestação, obteve comprimento de fibra significativamente maior aos demais tratamentos, sendo que os herbicidas de manejo não diferenciaram-se entre si, mas, com exceção do Par, superaram a Test $\mathrm{s} / \mathrm{c}$ que teve $\mathrm{o}$ menor comprimento de fibra devido a maior competição com as infestantes LAMAS (1988) analisando a 
TABELA 19 - Características tecnológicas das fibras do algodoeiro implantado em semeadura direta em função de diferentes preparos antecipados do solo e manejo das plantas daninhas.

\begin{tabular}{|c|c|c|c|c|c|}
\hline $\begin{array}{l}\text { Preparo do } \\
\text { solo }\end{array}$ & $\begin{array}{l}\text { Comprimento da } \\
\text { fibra (mm) }\end{array}$ & $\begin{array}{l}\text { Finura } \\
\text { (micronaire) }\end{array}$ & $\begin{array}{l}\text { Tenacidade } \\
\text { (g/tex) }\end{array}$ & Uniformidade & $\begin{array}{l}\text { Maturidade } \\
(\%)\end{array}$ \\
\hline Grade & $26,51 \mathrm{a}$ & $4,17 \mathrm{a}$ & $20,44 a$ & $46,14 a$ & $59,51 \mathrm{a}$ \\
\hline Arado & $26,54 a$ & $4,19 \mathrm{a}$ & $20,49 a$ & $46,06 \mathrm{a}$ & $59,99 a$ \\
\hline Grade + arado & $26,57 \mathrm{a}$ & $4.20 \mathrm{a}$ & $20,47 a$ & $46,10 \mathrm{a}$ & $60,03 \mathrm{a}$ \\
\hline $\mathrm{F}$ & $1,21^{\mathrm{ns}}$ & $1,25^{\mathrm{ns}}$ & $1,55^{\mathrm{ns}}$ & $0,11^{\mathrm{ns}}$ & $2.46^{\mathrm{ns}}$ \\
\hline $\mathrm{CV}(\%)$ & 1,19 & 3,01 & 1,49 & 1,55 & 1,35 \\
\hline $\operatorname{DMS}(5 \%)$ & 0,11 & 0,09 & 0,21 & 0.55 & 0,66 \\
\hline Manejo das P.D. & & & & & \\
\hline Test c/c & $26,88 \mathrm{a}$ & $4,48 \mathrm{a}$ & $21,26 \mathrm{a}$ & $47,12 \mathrm{a}$ & $62,85 \mathrm{a}$ \\
\hline Glyphosate & $26,58 \mathrm{~b}$ & $4,21 \mathrm{ab}$ & $20.86 \mathrm{ab}$ & $46,23 b$ & $60,15 b$ \\
\hline Paraquat + Diuron & $26,50 \mathrm{~b}$ & $4,18 b$ & $20,81 \mathrm{~b}$ & $46,19 b$ & $59.73 b$ \\
\hline Paraquat & $26,42 b c$ & $4,17 \mathrm{~b}$ & $20,78 b$ & $46,20 \mathrm{~b}$ & $59,72 b$ \\
\hline Test s/c & $26.30 \mathrm{c}$ & $3,88 \mathrm{c}$ & $18,72 \mathrm{c}$ & $44,79 \mathrm{c}$ & $56.77 \mathrm{e}$ \\
\hline $\mathrm{F}$ & $48,28^{* *}$ & $9,67^{* *}$ & $100,73^{* *}$ & $14,96^{\mathrm{ns}}$ & $127,10^{* *}$ \\
\hline $\mathrm{CV}(\%)$ & 4,02 & 5,73 & 6,19 & 6,12 & 5,17 \\
\hline $\operatorname{DMS}(5 \%)$ & 0,18 & 0,28 & 0,40 & 0,87 & 0,77 \\
\hline Interação $\mathbf{P} \times \mathrm{F}(\mathrm{F})$ & $0,22^{\mathrm{ns}}$ & $0,40^{\mathrm{ns}}$ & $0,25^{\mathrm{ns}}$ & $0,33^{\text {ns }}$ & $1,67^{\mathrm{ns}}$ \\
\hline
\end{tabular}

\footnotetext{
* F significativo a $5 \%$

** F significativo a $1 \%$

ns F não significativo
}

Médias seguidas para mesma letra não diferem entre si pelo teste de Tukey, ao nivel da $5 \%$ de probabilidade. 
competição intraespecífica, encontrou um menor comprimento da fibra no maior nível de competição, enquanto HACKETT \& MURRAY (1987) trabalhando com infestação de Hoffmansegia glauca em algodoeiro, também verificaram redução no comprimento das fibras produzida pela cultura. No entanto, outros pesquisadores avaliando a competição de plantas daninhas com a cultura do algodoeiro, não encontraram resultados significativos para essa característica, como foi o caso de EL-SHAER et al (1985), RUSHING et al (1986) e GREEN et al. (1988).

A figura está associada ao grau de maturidade da fibra, influindo diretamente na regularidade e tenacidade do fio. As menores infestações de plantas daninhas ocorridas na Test $\mathrm{c} / \mathrm{c}$ e Gly fizeram estes tratamentos superarem a Test $\mathrm{s} / \mathrm{c}$, que obteve $o$ menor índice micronaire e diferiu também dos tratamentos com herbicidas, que foram semelhantes entre si. HACKETT \& MURRAY (1987) também verificaram diminuição do índice micronaire com maior infestação de plantas daninhas, e LAMAS (1988) concluiu que, quanto maior a competição instraespecífica na cultura do algodoeiro, mais fina são as fibras produzidas, enquanto BELLETTINI (1988) e BANCIN (1992) não encontraram influência desse tipo de competição nessa característica de fibra.

A tenacidade da fibra determina a tenacidade do fio obtido, sendo uma das principais propriedades consideradas na qualidade do algodão pelas indústrias. $\mathrm{O}$ resultado obtido para tenacidade foi idêntico ao da finura. HACKETT \& MURRAY (1987) e LAMAS (1988) que verificaram diferenças significativas para finura, não obtiveram esse mesmo resultado para tenacidade das fibras, o que também não foi 
constatado por HIGGINS et al. (1985); BROW \& WHITWELL (1985b) e GREEN et al. (1988).

A uniformidade da fibra indica a presença de fibras mais curtas no material, prejudicando a tenacidade, regularidade e aparência do fio, e aumentando o desperdício nas máquinas de beneficiamento e do equipamento industrial. Os resultados mostram que existiu a tendência de uma maior uniformidade sempre que ocorreu uma menor infestação de plantas daninhas, onde a Test $\mathrm{c} / \mathrm{c}$ obteve a maior porcentagem diferindo-se dos demais tratamentos, enquanto os herbicidas mostraram comportamento semelhante, mas superior a Test s/c. Uma possível explicação para tais resultados seria a competição, principalmente por nutrientes e água, que a cultura sofreu na fase de alongamento das fibras, provocando distúrbios em relação a homogenização em comprimento de suas fibras. No entanto, tal afirmação não é constatada por EL-SHAER et al. (1985); RUSHING et al. (1986); HACKETT \& MURRAY (1987) e GREEN et al. (1988)

A maturidade representa a quantidade de celulose depositada na fibra, podendo causar quebra da mesma no processamento e depreciação dos tecidos pela diferenciação na absorção de corantes. Os resultados obtidos para essa característica foram semelhantes aos encontrados para uniformidade, mostrando também a tendência de um maior grau de maturidade com a menor infestação de plantas daninhas. A competição por luz, nutrientes e água, exercidas pela comunidade infestante na fase de deposição de celulose que vai dos 21 aos 56 dias após a abertura da flor (GRIDI-PAPP, 1992), também pode servir de explicacão para tais resultados obtidos HACKETT \& MURRAY (1987); GREEN et al. (1988); RUSHING et al. 
(1986) e EL-SHAER et al. (1985), não encontraram diferença nessa característica da fibra na competição do algodoeiro com plantas daninhas. 


\section{CONCLUSÕES}

Baseando-se nas condições em que se desenvolveu o experimento, os resultados obtidos permitem as seguintes conclusões:

a) $\mathrm{O}$ preparo mais profundo do solo obtido pela incorporação dos restos vegetais pela grade aradora seguido da aração com arado de discos resultou menor infestação total de plantas daninhas, tanto em densidade quanto em peso da biomassa seca, do que o preparo mais superficial do solo obtido pela grade aradora isoladamente.

b) Os herbicidas paraquat e a mistura paraquat + diuron propiciaram um controle insuficiente, abaixo de $80 \%$, para $D$. horizontalis, enquanto que o glyphosate obteve $100 \%$ de controle para essa espécie. Isso resultou em menor infestação final, tanto em densidade como em acúmulo de biomassa seca, para $D$. horizontalis e consequentemente total de monocotiledôneas, dos tratamentos com glyphosate em relação aos dos outros herbicidas, sem no entanto, provocar diferença no resultado final do total de plantas daninhas.

c) A aplicação do herbicida de manejo isoladamente, não foi suficiente para um controle eficaz das plantas daninhas durante o ciclo da cultura. 
d) A mato-interferência causou sensíveis reduções nas características fitotécnicas do algodoeiro como altura, diâmetro do caule, número de ramos produtivos, número de capulhos por planta, peso de um capulho e peso de 100 sementes, reduzindo em menor proporção a precocidade de colheita A altura de inserção do primeiro ramo produtivo aumentou sensivelmente com a maior infestação das plantas daninhas, sendo que o aparecimento do primeiro capulho foi levemente adiada por essa infestação. A porcentagem de fibras não foi alterada pela competição da cultura com as plantas daninhas.

e) Maiores produções de algodão em caroço foram obtidas nos tratamentos com menor infestação de plantas daninhas.

f) As fibras de algodão tiveram redução na sua qualidade a medida que se aumentou a mato-interferência, pois essa competição prejudicou os resultados de comprimento, finura, tenacidade, uniformidade e maturidade das fibras obtidas. 


\section{REFERÊNCIAS BIBLIOGRÁFICAS}

ABRAHÃO, J.T.M. Técnica cultural do algodão Coordenadoria de Assistência Técnica Integral/CATI Curso básico da cultura do algodão. Campinas, CATI/CETATE, 1985.29P.

ALMEIDA, F.S. Controle de ervas In: Fundação Instituto Agronômico do Paraná Plantio direto no estado do Paraná Londrina, IAPAR, 1981 p. 101144.

ALMEIDA, F.S. Controle de plantas daninhas em plantio direto. Londrina, IAPAR, $1991.34 \mathrm{p}$.

ALMEIDA, F.S.; OLIVEIRA, V.F, RODRIGUES, B.N. Influência do sistema de preparo de solo na atuação dos herbicidas. In: CONGRESSO BRASILEIRO DE HERBICIDAS E PLANTAS DANINHAS, 14 Campinas, 1982. Resumos. Campinas, SBHED, 1982, p.20-27. 
ALMEIDA, F.S.; RODRIGUES, B.N.; OLIVEIRA, V.F. Resultados de pesquisa da área de herbologia do IAPAR-safra 1982/83 Londrina, IAPAR, $1983.167 \mathrm{p}$

ALMEIDA, F. S. \& RODRIGUES, B. N Guia de Herbicidas; Recomendaçóes para o uso adequado em plantio direto e convencional. Londrina, IAPAR, 1985. 482p

ALMEIDA, F.S.; RODRIGUES, B.N; VIDAL, R.A., LEITE, C.R.F. Subsídio para o estudo do desempenho da cobertura morta na densidade de infestação das culturas de verão, em plantio direto. In: CONGRESSO BRASILEIRO DE HERBICIDAS E PLANTAS DANINHAS, 16, Campo Grande, 1986. Resumos Campo Grande, SBHED, 1986. p.13-14.

ANDREI, E. coord Compêndio de Defensivos Agricolas $4^{\text {a }}$ ed. São Paulo, Org. Andrei Editora Ltda, 1993. 448p.

ANTUNIASSI, U.R Infestação por plantas daninhas e produção da cultura do milho em função de diferentes intervalos de tempo entre a mobilização do solo e a semeadura Botucatu, 1991. 73p. (Mestrado - Faculdade de Ciências Agrárias e Veterinárias) 
AZEVEDO, D.M.P.; BELTRÃO, N.E.M.; LIMA, R.N. Competição entre plantas daninhas e o algodoeiro herbáceo (Gossypium hirsutum L.) na Paraiba e Pernambuco In CONGRESSO BRASILEIRO DE HERBICIDAS E PLANTAS DANINHAS, 12, Fortaleza (CE), 1978. Resumos Fortaleza, SBHED, 1978, p.41- 42 .

BAKER, S.H. Response of cotton to row patterns and plant population. Agronomy Journal, Madison, 68(1):85-88, 1976

BANCI, C.A. Espaçamento entre fileiras e doses do regulador de crescimento cloreto de mepiquat, em três épocas de plantio, na cultura do algodoeiro herbáceo Viçosa, 1992 81p (Mestrado - Universidade Federal de Viçosa).

BANKS, J.C. Early season weeds and their management In Beltwide cotton production conference, Memphis, 1990 Proceedings National Cotton Concil of America, 1990 p.48-49 Apud Weed Abstracts, Farnhan Royal, 41:3888, 1992. (Resumo).

BELLETTINI, S. Comportamento do algodão "IAC-20" em diferentes espaçamentos e distribuções espaciais. Piracicaba, 1988. 101p. (Mestrado Escola Superior de Agricultura "Luiz de Queiroz"/USP). 
BELTRÃO, N.E.M.; AZEVEDO, D.M.P.; LIMA, R.N. Interação entre os feitos da competição de plantas daninhas, da adubação nitrogenada e da cultivar em algodoeiro herbáceo. IN: EMBRAPA-CNPA. Tratos culturais I. Campina Grande, EMBRAPA-CNPA, 1983 p. 5-19. (Boletim de Pesquisa 3).

BENEDICT, C.R. Physiology. In: Kohel, R.J. \& Lewis, C.F., ed Cotton Madison, American Society of Agronomy, 1984. p. 151-200

BEZERRA, J. E. S.; CARVALHO, O. S.; SILVA, O.R.R.F. Influência de diferentes sistemas de manejo do solo sobre a produção do algodoeiro (Gossypium hirsutum L.) em solo depauperado de Surubim-PE. In: Reunião Nacional do Algodão, 1, Londrina, 1980 Resumos. Campina Grande, EMBRAPA/CNPA, 1980. p.81.

BLANCO, H.G. A importância dos estudos ecológicos nos programas de controle de plantas daninhas. O Biológico, São Paulo, 38(10):343-350, 1972.

BLANCO, H. G.; ARÉVALO, R. A.; CHIBA S. Convivência de populações de Cyperus rotundus L. com plantas de algodoeiro herbáceo Pesq. Agrop. Bras., Brasilia, 26(2):169-176, fev. 1991

BLANCO, H.G. \& OLIVEIRA, D.A. Contribuição para determinação do período de competição das plantas daninhas na cultura do algodoeiro (Gossypium hirsutum). O Biológico, São Paulo, 42(9):201-205, 1976. 
BROWN, S. M.; CHANDLER, J.M.; MORRISON, J.E. Weed control in a conservation tillage rotation in the Texas Blacklands. Weed Science, Champaign, 35(5):695-699, 1987.

BROWN, S.M. \& WHITWELL, T. Weed control programs for minimum tillage cotton (Gossypium hirsutum L.) Weed Science, Champaign, 33(6):843-847, 1985a.

BROWN, S.M. \& WHITWELL, J Common bermudagrass competition in cotton. IN: ANNUAL METTING SOUTHERN WEED SCIENCE SOCIETY, 36, 1983. Proceedings. 1983, p.314. Apud Weed Abstracts, Champaign, Farnhan Royal, 34:3055, 1985b (Resumo).

BROWN, S.M. \& WHITWELL, T. Influence of tillage on horsewweed, Coniza canadensis. Weed-Technology, Champaign, 2(3):269-279, 1988.

BRUCE, J.A \& KELLS, JJ Horseweed (Coniza canadensis) control in notill soybeans (Glycine max) with preplant and pre-em herbicides Weedtecnnology, Champaign, 4(3):642-647, 1990.

BRUFF, S.A \& SHAW, D.R Early season herbicide applications for weed control in stale seedbed soybean (Glycine max). Weed-Tecnnology, Champaign, 6(1):36- 44, 1992. 
BUHLER, D.D. Population dynamics and control of annual weeds in corn as influenced by tillage systems. Weed Science, Champaign, 40(2):241-248, 1992

BUHLER, D.D. \& MESTER, T.C. Effect of tillage systems on the emergence depth of giant (Setaria faberi). Weed Science, Champaign, 39(2):200-203, 1991.

CAMARGO, M.N.; KLAMT, E.; KAUFFMAN, J.A. Classificação de solos usada em levantamento pedológicos no Brasil. Boletim informativo da Sociedade Brasileira de Ciências do Solo, Campinas, 12: 11-33, 1987.

CARNEIRO, G.E.S. Consorciação de culturas. In Paraná, Secretaria da Agricultura e Abastecimento. Manual Técnico do Subprograma de Manejo e Conservação do Solo. Curitiba, SEAB, 1989. p.180-184.

CARVALHO, L.H. Preparo periódico do solo e colheita mecanizada na cultura do algodoeiro. In: CICLO DE ESTUDOS SOBRE MECANIZAÇÃO, 4, Campinas, 1990. Anais Campinas, Fundação Cargill, 1990. p.53-64.

CASTRO, O.M Preparo do solo para a cultura do milho. Campinas, Fundação Cargill, 1989. 41p. 
CASTRO, O. M. Avaliação de sistemas de manejo de solo. In: CICLO DE ESTUdOS SOBRE MECANIZAÇÃO AGRÍCOLA, 4. Campinas, 1990. Anais. Campinas, Fundação Cargill, 1990. p.34-38.

CIA, E., coord Competição de plantas daninhas com a cultura do algodoeiro. Bragantia, Campinas, 37:53-62, 1978.

COLWICK, R.F.; LALOR, W.F.; WILKES, L.H Harvesting. In: KOHEL, R.J. \& LEWIS, C.F. ed. Cotton. Madison, American Society of Agronomy, 1984. p.367-395.

CORTEZ, M.G. \& KLENKI, C.A. Efeito do manejo do solo em restos culturais de trigo, no controle de plantas daninhas em soja. IN: CONGRESSO BRASILEIRO DE HERBICIDAS E PLANTAS DANINHAS, 19, Londrina. Resumos. Londrina, SBHED, 1993. p. 100-101.

CUSSANS, G.W Weed control in reduced cultivation and direct drilling systems. Outlook on agriculture, 8:240-242, 1975.

DEMÉTRIO, C.G.B. Transformação de dados, efeito sobre a análise de variância. Piracicaba, 1978 113p. (Mestrado-Escola Superior de Agricultura "Luiz de Queiroz"/USP). 
DERTING, C.W. Return on investment in no-tillage v.s. conventional tillage in cotton. In: Anual Meeting of the Southern Weed Science Society, 43. 1990 Proceedings 1990. p. 76-79. Apud Weed Abstracts, Farnhan Royal, 40: 1054, 1991. (Resumo).

DEUBER, R. Ciência das Plantas Daninhas: Fundamentos. Jaboticabal, FUNEP, 1992, v.1, 431p.

EL-SHAER, M.H.; ABDEL-RAOUF, M.S.; SAMRA, A.M.; ALI, H.A. Effect on plant population density and weed control treatments on weed dry weight and cotton yield and quality. Annals of Agricultural Science of Ain Shams University, Cairo, 28(3):1291-1307, 1983. Apud Weed Abstracts, Farnhan Royal, 34:870, 1985. (Resumo).

FANCELLI, A.L. \& FAVARIN, J.L. Desempenho da cultura do milho em plantio direto e convencional In: ENCONTRO PAULISTA DE PLANTIO DIRETO, 1. Campinas, 1989. Resumos. Piracicaba, FEALQ/ESALQ, 1989. P.174-175

F.A.O Manejo de Malezas: Manual del Instructor C.I.P.V. Corvallis (OR), USA, 1987. 160p. 
FORSTER, R.; CERDEIRA, A.L. Multiplicação vegetativa da tiririca (Cyperus rotundus L.) IN CONGRESSO BRASILEIRO DE HERBICIDAS E PLANTAS DANINHAS, 19, Londrina, 1993. Resumos. Londrina, SBHED, 1993, P. 24-25

FOWLER, J.L. \& RAY, L.L. Response of two cotton genotypes to five equidistant spacing patterns. Agronomy Journal, Madison, 69(5):733-738, 1977.

GOMES, F.P. Curso de Estatística Experimental $13^{\mathrm{a}}$ ed. Piracicaba, Liv. Nobel, 1990. 468p.

GONG, Q.W. \& LI, P. Effects of no-tillage on weed occurrence Journal of Weed Science, 5(4) 7-14, 1991. Apud Weed Abstracts, Fanhan Royal, 42:290, 1993. (Resumo).

GREEN, J.D.; MURRAY, D.S.; VERHALEN, L.M. Relationship of silverleaf nightshade with cotton IN: ANNUAL MEETING OF SOUTHERN WEED SCIENCE SOCIETY, 39, 1986. Proceedings. 1986, p. 397. Apud Weed Abstracts, Farnham Royal, 37:2963, 1988. (Resumo)

GRIDI-PAPP, I.L., coord. Manual do produtor de algodão. São Paulo, Bolsa de Mercadorias \& Futuros, 1992. 158p. 
GUERRA FILHO, T. Comportamento do algodoeiro (Gossipium hirsutum L.) em diferentes densidades de plantio sob períodos de competicão com plantas daninhas. Viçosa, 1980 $81 \mathrm{p}$ (Mestrado-Universidade Federal de Viçosa).

HACKETT, N.M. \& MURRAY, D.S. Biological studies with hogpotato In: NORTH CENTRAL WEED CONTROL CONFERENCE, 40, St Louis, 1985. Proceedings St Louis, 1985, p.6. Apud Weed Abstracts, Farnham, Royal, 36:2516, 1987. (Resumo).

HARMAN, W.L; MICHELS, G.J.; WIESE, A.F. A conservation tillage system for profitable cotton production in the Central Texas High Plains Agronomy Journal, Madison, 81: (4)615-618, 1989.

HIGGINS, JM; WALKER, RH WHITWELL, T,; Mc GUIRE, JA. Coffee senna interference in cotton. IN: ANNUAL MEETING OF SOUHTERN WEED SCIENCE SOCIETY, 36, 1983 Proceedings 1983, p. 19. Apud Weed Abstracts, Farnhan Royal, 34:2566, 1985. (Resumo).

HIGGINS, J.M; WHITWELL, T, TOLER, J.E. Common lambsquarters (Chenopodium album) control with non-selective herbicides Weed-Tecnnology, Champaign, 5(4):884-886, 1991 . 
HOLM, L.R.G.; PLUCKNET, D.L.; PONCHO, J.V.; HERBERGER, J.P. The worlds's worst weeds: Distribution an biology. Honolulu, The East-west center by the University Press of Hawaii, 1977.609p.

HURST, H.R. The influence of winter vegetation on seedbed preparation and weed control in cotton Bulletin Mississippi Agricultural and Forestry Experiment Station, n. 958, 1989. 10p.

IAPAR Manual Agropecuário para o Paraná. vol. 2 Londrina, Fund IAPAR, 1978. $743 p$

IKE, I.F. Soil and crop responses to different tillage practices in a ferruginous soil in the Nigerian Savanna Soil and Tillage Research, 6(3):261-272, 1986.

IKE, I.F. Maize and cotton yield responses to different tillage practices in a sandy loam soil of the Nigerian Savanna. Journal of Agricultural Research, 5:25-34, 1987. Apud Weed Abstracts, Farnhan Royal, 38:2735, 1989. (Resumo).

JOHNSON, R.R. A new look at cultivation: Tillage can boost yields and cut erosion. Crops and Soil Magazine, Madison, 37(8) 13-16, 1985.

KLUTHCOUSKI, J. O arroz nos sistemas agrícolas do cerrado. In: REUNIÃO NACIONAL DE PESQUISA DO ARROZ, 3, Goiânia, 1987. Resumos Goiânia, EMBRAPA/CNPAF. 1987, p.282-318 
KOCH, D. W.; WHITSON, T.D.; FERRER, M.A.; NIX, K.J. Herbicides and adjuvants for sod control prior to no-till seeding of alfafa. In: Annual meeting of Western Society of Weed Science, 42, 1989. Proceedings. 42:29-32, 1989. (Resumo)

KRANZ, W.M. Plantas invasoras mais frequentes e mais importantes no Estado do Paraná Londrina, IAPAR, 1991, 16p

KURTZ, M.E. \& HURST, H.R Effects of tillage and herbicides on Bermuda grass control in cotton. Mafes Research Highlights, 46:3-4, 1983. Apud Weed Abstracts, Farnhan Royal, 33:505, 1984. (Resumos).

LACA-BUENDIA, J.P.C. Controle de plantas daninhas em algodoeiro. Informe Agropecuário, Belo Horizonte, 15(166):34-47, 1990.

LACA-BUENDIA, J.P.C.; PURCINO, A.A.C,; PENNA, J.C.V.; FERREIRA, L. Período crítico de competição entre comunidades de plantas daninhas e o algodoeiro (Gossypium hirsutum L.) no Estado de Minas Gerais. Planta daninha, 2:89-95, 1979

LEITÃO $\mathrm{F}^{\circ}$, H.F; ARANHA, C; BACCHI, O. Plantas invasoras de culturas no Estado de São Paulo. V 1 e 2. São Paulo, Hucitec Ltda., 1972. 597p. 
LORENZI, H. Manual de Identificação e controle de Plantas Daninhas: Plantio direto e convencional. $4^{a}$ ed. Nova Odessa. Ed. Plantarum, 1994. 276p.

MARUR, C.J Crescimento e desenvolvimento do algodoeiro In IAPAR Recomendaçôes para a cultura do algodoeiro no Paraná. Londrina, IAPAR, 1993. P. 2-7. (Inf de Pesquisa, 107).

MEDEIROS, J.C. \& SANTOS, J.W Efeito do preparo de solo sobre o rendimento do algodão herbáceo. In REUNIÃO DO ALGODÃO, 6, Campina Grande, 1990. Resumos, 1990. Campina Grande, EMBRAPA/CNPA, 1990 . p. 169.

MONTEMAYOR, M.B. Cotton and weed seedling emergence as affected by seedbeed preparation Agricultural mechanization in Asia, Africa and Latin America, 23(1):39-41, 1992.

MORAES, J.D.; CERQUEIRA, W.P.; SANTANA, A.C, SILVA, R.J.M. Periodo crítico de competição entre plantas daninhas e o algodoeiro (Gossypium hirsutum L.) no Estado de Goiás. In REUNIÃO NACIONAL DO ALGODÃO, 2 , Salvador, 1982. Resumos. Campina Grande, EMBRAPA/CNPA, 1982, p. 132.

MOSELEY, C.M. \& HAGOOD, E.S. Horseweed (Conyza canadensis) control in full-season no-till soybeans (Glycine max.) Weed-Technology, 4(4):814-818, 1990. 
NIETO, J.; NIETO-PALLAS, J.; PALLAS, J.N. Soil management in almonds. In: EWRS Symposium on weed problems in mediterranean climates, 4, 1989 Proceedings. 1: 102-109, 1989.

OLIVEIRA, JR R.S. Controle de planta daninhas e seletividade do oxyfluorfen e ioxynil-octanoato para cebola em semeadura direta. Viçosa, 1994. 111p. (Mestrado - Universidade Federal de Viçosa).

PAREJA, M.R; STANIFORTH, D.W.; PAREJA, G.P. Distribution of weed seed among soil structural units. Weed Science, Champaign, 33:182-189, 1985.

PARRY, G. Le cotonnier et ses produits. Paris, G.P. Maisonneuve \& Larose, 1982. 502p.

PIMENTEL, C.R.M A avalią̧ão econômica de diferentes sistemas de preparo do solo na cultura do algodoeiro arbóreo no Estado da Paraíba. In: REUNIÃO NACIONAL DO ALGODÃO, 1, Londrina, 1980. Resumos Campina Grande, EMBRAPA/CNPA, 1980, p.130.

PITELLI, R.A. Interferência de plantas daninhas em culturas agrícolas. Informe Agropecuário, Belo Horizonte, 11(129): 16-27, 1985a.

PITELLI, R.A. Manejo Integrado de plantas daninhas. In CREA-SP. Controle Integrado de Plantas Daninhas, $2^{\mathrm{a}}$ ed. São Paulo, CREA-SP, 1985b. p.27-41 
ROBINSON, E.L. Effect of weed species and placement on seed cotton yields. Weed Science, Champaign, 24(4):353-355, 1976.

RODRIGUES, B.N. Utilização de herbicidas em plantio direto. In: FANCELLI, A.L. Coord Atualização em Plantio Direto Campinas, Fund Cargill, 1985 p.49-85.

RUSHING, D.W; MURRAY, D.S; VERHALEN, L.M. Tumble pigweed interference with cotton In: ANNUAL MEETING OF SOUTHERN WEED SCIENCE SOCIETY, 37, 1984. Proceedings 1984. p.314. Apud Weed Abstracts, Farnhan Royal, 35:4003, 1986. (Resumo).

SALOME, A.S. Chemical control of weeds in cotton. In: annual Meeting of Southern Weed Science Society, 39, 1986. Proceedings 1986. p.487. Apud Weed Abstracts, Farnhan Royal, 37:986, 1988 (Resumo).

SANTOS, W.J. Pragas do algodoeiro. In: IAPAR Recomendações para a cultura do algodoeiro no Paraná. Londrina, IAPAR, 1993. p.37-63.(Inf. de Pesquisa, 107).

SEGUY, L.; KLUTHCOUSKI, J.; SILVA, J.G.; BLUMENSCHEIN, F.N. Técnicas de preparo do solo - efeitos na fertilidade e na conservação do solo, nas ervas daninhas e na conservação da água. Goiânia, EMBRAPA/CNPAF, 1984. 26p. (Circular técnica, 17) 
SILVEIRA, G.M O preparo do solo: implementos corretos. São Paulo, Ed. Globo, 1989. 243p.

SOANE, B.D \& RODGER, J.B.A. Soil and cereal crop response to direct drilling and normal cultivations on heavy soil in Eastern Scotland Experimental Husbandry, Scotland, 27:68-78, 1974.

SUMMA AGRÍCOLA Commodities-Algodão, Rio de Janeiro, Ed. Tama, n.279, 1993. p.11

TANG, H.Y. \& WANG, X.E. A survey of main weed damage in Shangai, with suggestions for control Acta Phytophylactica Sinica, 13:211-216, 1986. Apud Weed Abstracts, Farnhan Royal, 35:3872, 1986. (Resumo).

TEASDALE, J.R.; BESTE, C.E; POTTS, W.E. Response of weeds to tillage and cover crop residue. Weed Science, Champaing, 39(2):195-199, 1991.

THARP, W.H. The cotton plant, how it growns and why its growth varies. USDA Handbook 178, 1960. 17p.

TOUCHTON, J.T. \& REEVES, D.W. A Beltwide look at conservation tillage for cotton. In: BELTWIDE COTTON PRODUCTION CONFERENCE, New Orleans, 1988. Proceedings. Memphis, National Cotton Council, 1988 p.36-41. 
VEDOATO, R.A. \& WILLES, T.L. Estudo integrado de plantio direto, cultivo mínimo e controle de ervas daninhas em soja/trigo no norte do Paraná. In: CONGRESSO BRASILEIRO DE HERBICIDAS E PLANTAS DANINHAS, 11 , Londrina, 1976. Resumos. Londrina, SBHED, 1976. p.97.

VICTORIA FILHO, R Potencial de ocorrência de plantas daninhas em plantio direto. IN: FANCELLI, A.L. Coord. Atualização em plantio direto. Campinas, Fund Cargill, 1985, p.49-85.

VIOLOC, A.D.; PALMER, A.F.E.; KOCHER, F. Weed control in maize: CIMMYT experiments in conservation tillage in low-lying tropics of Vera Cruz, México. $\mathrm{IN}$ : SEMINÁRIO LABRANZA DE CONSERVACION EN MAIZ, Quito. 1989. Resumenes. Quito, CIMMYT, 1989. p.119-131.

VOLL, E. Efeitos do manejo da resteva do trigo, do preparo do solo e de herbicidas no controle de plantas daninhas na cultura da soja (Glycine max 2 Piracicaba, 1987. 158p. (Tese-Doutorado - Escola Superior de Agricultura "Luiz de Queiroz/USP).

WADDLE, B.A. Crop growing practices. In: Kohel, R.J. \& LEWIS, C.F. ed. Cotton. Madison, American Society of Agronomy, 1984 p.233-263. 
WHITE, R.H. \& WORSHAM, A.D. Control of legumes cover crops in no-till corn (Zea mays) and cotton (Gossypium hirsutum). Weed-Technology, Champaign, 4:(1)57-62, 1990 .

WIEPKE, T. Influence of legume and rye mulches on no-till flue-cured tobacco, soil reception and dissipation of diphenamid and weed suppression. Sciences and Enginnering, 51:(2), 491B, 1990.

YAMAOKA, R.S. Desenvolvimento e práticas culturais do cultivo do algodoeiro. In: IAPAR Curso da cultura do algodoeiro no Estado do Paraná, Londrina, IAPAR, 1991. 30p (Apostila)

YAMAOKA, R.S.; PIRES, J.R.; ALMEIDA, W.P. Efeito da densidade de plantas do algodoeiro sobre a inserção de ramos frutíferos. In: REUNIÃO NACIONAL DO ALGODÃO, 2, Salvador, 1982. Resumos Campina Grande, EMBRAPA/CNPA, 1982. p. 109.

YAMAOKA, R.S \& PIRES, J.R. Práticas culturais. In: IAPAR Recomendações para a cultura do algodoeiro no Paraná. Londrina, IAPAR, 1993, P. 17-27. (Inf. de Pesquisa, 107)

YOO, K.H.; TOUCHTON, J.T.; WALKER, R.H. Runoff, sediment and nutriente losses from various tillage systems of cotton. Soil and Tillage Research, 12(1): 13-24, 1988 . 
APÊNDICE 
TABELA 20 - Dados climatológicos amostrados dentro do periodo de aplicação dos herbicidas de manejo. dia $29 / 10 / 93$.

\begin{tabular}{|c|c|c|c|c|}
\hline Horário & $\begin{array}{c}\text { Temp.solo a } 5 \mathrm{~cm} \\
\text { prof. }\left({ }^{\circ} \mathrm{C}\right)\end{array}$ & Temp ATM. & $\begin{array}{c}\text { U. R. do ar } \\
(\%)\end{array}$ & $\begin{array}{l}\text { Velocidade } \\
\text { vento }(\mathrm{m} / \mathrm{s})\end{array}$ \\
\hline $9: 05$ & 22,0 & 19.2 & 61 & 0,20 \\
\hline $9: 20$ & 22,5 & 20.5 & 59 & 0.20 \\
\hline $9: 35$ & 22,9 & 21,6 & 56 & 0.20 \\
\hline $9: 50$ & 23,2 & 22.0 & 54 & 0,32 \\
\hline $10: 05$ & 23,5 & 22,8 & 51 & 0,28 \\
\hline $10: 20$ & 23,7 & 23,3 & 48 & 0,25 \\
\hline $10: 35$ & 24,0 & 24,0 & 46 & 0,28 \\
\hline $10: 50$ & 24,2 & 25.2 & 45 & 0.30 \\
\hline
\end{tabular}


TABELA 21 - Registros metereológicos diarios, do mès de setembro de 1993 em Piracicaba-SP

\begin{tabular}{|c|c|c|c|c|c|c|}
\hline Dia & $\begin{array}{l}\text { Insolação } \\
\mathrm{h} / \mathrm{d}\end{array}$ & $\begin{array}{l}\text { Precipitação } \\
\text { mm/alt. }\end{array}$ & $\begin{array}{l}\text { Umidade } \\
\text { relativa } \\
\%\end{array}$ & $\begin{array}{l}\text { Temp máxima } \\
{ }^{\circ} \mathrm{C}\end{array}$ & $\begin{array}{l}\text { Temp. } \\
\text { minima } \\
{ }^{\circ} \mathrm{C}\end{array}$ & $\begin{array}{l}\text { Temp. } \\
\text { média } \\
{ }^{\circ} \mathrm{C}\end{array}$ \\
\hline 1 & 8,60 & 0,00 & 74,00 & 32.60 & 18,50 & 25.55 \\
\hline 2 & 8,30 & 0,00 & 71,00 & 32,40 & 16,10 & 24,25 \\
\hline 3 & 4,30 & 0,00 & 83,00 & 26,20 & 17,20 & 21,70 \\
\hline 4 & 6,50 & 1,00 & 84,00 & 23.60 & 14,50 & 19,05 \\
\hline 5 & 9,50 & 0,00 & 74,00 & 29,70 & 11,30 & 20,50 \\
\hline 6 & 9,40 & 0.00 & 65,00 & 34,10 & 14.70 & 24,40 \\
\hline 7. & 6,30 & 6.50 & 73,00 & 32.30 & 16,40 & 24,35 \\
\hline 8 & 0,00 & 0,40 & 97,00 & 21.80 & 18,00 & 19.90 \\
\hline 9 & 1,10 & 0,00 & 95,00 & 24,00 & 16,90 & 20,45 \\
\hline 10 & 1,00 & 3,20 & 91,00 & 23,60 & 15,20 & 19.40 \\
\hline 11 & 0,00 & 0,40 & 92.00 & 18,80 & 14,20 & 16,50 \\
\hline 12 & 9,10 & 0,00 & 78,00 & 24,00 & 12,00 & 18,00 \\
\hline 13 & 9,50 & 0,00 & 75,00 & 26.70 & 11,50 & 19,10 \\
\hline 14 & 1,30 & 14,00 & 87,00 & 22,00 & 12,50 & 17,25 \\
\hline 15 & 1,00 & 26,60 & 94,00 & 22,40 & 15,40 & 18,90 \\
\hline 16 & 7,90 & 0,00 & 85.00 & 26.60 & 14,00 & 20,30 \\
\hline 17 & 8,60 & 0,00 & 77.00 & 28,60 & 12.20 & 20,40 \\
\hline 18 & 10,30 & 0,00 & 68,00 & 30,00 & 12,20 & 21.10 \\
\hline 19 & 6,20 & 0,00 & 73,00 & 31,80 & 14,20 & 23,00 \\
\hline 20 & 8,20 & 4,50 & 80,00 & 33,50 & 17,10 & 25,30 \\
\hline 21 & 0,00 & 15,20 & 97,00 & 24,40 & 18,20 & 21,30 \\
\hline 22 & 2,70 & 2,00 & 90,00 & 26,10 & 15,40 & 20,75 \\
\hline 23 & 0,00 & 17,50 & 98,00 & 20,80 & 15,90 & 18,35 \\
\hline 24 & 1,00 & 41,20 & 91,00 & 28,20 & 17,40 & 22,80 \\
\hline 25 & 3,10 & 0,00 & 83,00 & 25,20 & 17,30 & 21.25 \\
\hline 26 & 7,30 & 17,50 & 83,00 & 27,40 & 15,00 & 21,20 \\
\hline 27 & 0,40 & 4,00 & 98,00 & 24,20 & 18,80 & 21.50 \\
\hline 28 & 9,80 & 0,00 & 74.00 & 27.50 & 14,80 & 21,15 \\
\hline 29 & 4,80 & 0,00 & 81.00 & 28,70 & 14,60 & 21,65 \\
\hline 30 & 5,60 & 0,40 & 85,00 & 28,60 & 17,50 & 23.05 \\
\hline Média & 5,06 & 5,15 & 83,20 & 26.86 & 15,30 & 21.08 \\
\hline Total & 151.80 & 154,40 & 2496.00 & 805.80 & 459,00 & 632,40 \\
\hline
\end{tabular}


TABELA 22 - Registros metereológicos diários, do mês de outubro de 1993 em Piracicaba

\begin{tabular}{|c|c|c|c|c|c|c|}
\hline Dia & $\begin{array}{l}\text { Insolação } \\
\mathrm{h} / \mathrm{d}\end{array}$ & $\begin{array}{l}\text { Precipitação } \\
\mathrm{mm} / \mathrm{alt}\end{array}$ & $\begin{array}{l}\text { Umidade } \\
\text { relativa } \\
\%\end{array}$ & $\begin{array}{l}\text { Temp. máxima } \\
{ }^{\circ} \mathrm{C}\end{array}$ & $\begin{array}{l}\text { Temp. } \\
\text { minima } \\
{ }^{\circ} \mathrm{C}\end{array}$ & $\begin{array}{l}\text { Temp. } \\
\text { média } \\
{ }^{\circ} \mathrm{C}\end{array}$ \\
\hline 1 & 1,00 & 2,40 & 91,00 & 27,60 & 18,20 & 22,90 \\
\hline 2 & 5,60 & 0,00 & 88,00 & 29,50 & 17,00 & 23,25 \\
\hline 3 & 9,60 & 0,00 & 82,00 & 31,20 & 17,30 & 24,25 \\
\hline 4 & 6,80 & 6,00 & 83,00 & 32,10 & 17,30 & 24,70 \\
\hline 5 & 1,50 & 9,90 & 92,00 & 27,20 & 18,70 & 22,95 \\
\hline 6 & 7,50 & 0,00 & 82,00 & 24,00 & 15,60 & 19,80 \\
\hline 7 & 10,30 & 0,00 & 78,00 & 23,20 & 9,40 & 16,30 \\
\hline 8 & 11,00 & 0,00 & 74,00 & 27,60 & 12.20 & 19.90 \\
\hline 9 & 9,70 & 0,00 & 66,00 & 30,70 & 12,40 & 21,55 \\
\hline 10 & 9,80 & 0,00 & 62,00 & 32,60 & 15,40 & 24,00 \\
\hline 11 & 10,70 & 0,00 & 62,00 & 33,50 & 15,40 & 24,45 \\
\hline 12 & 10,20 & 0,00 & 62,00 & 33,30 & 16,20 & 24,75 \\
\hline 13 & 10,00 & 0,00 & 65,00 & $\mathbf{3 4 , 4 0}$ & 17,10 & 25,75 \\
\hline 14 & 9,00 & 0,00 & 62,00 & 34,40 & 16,60 & 25,50 \\
\hline 15 & 3,00 & 0,00 & 77,00 & 30,80 & 19,60 & 25,20 \\
\hline 16 & 0,00 & 0,60 & 85,00 & 27,60 & 19,00 & 23,30 \\
\hline 17 & 2,90 & 0,00 & 80,00 & 30,50 & 18,20 & 24,35 \\
\hline 18 & 6,00 & 0,30 & 78,00 & 30,50 & 18,00 & 24,25 \\
\hline 19 & 9.00 & 39,30 & 83.00 & 31,90 & 18,20 & 25,05 \\
\hline 20 & 9,30 & 1,10 & 79,00 & 32.20 & 18,60 & 25,40 \\
\hline 21 & 8,50 & 0,00 & 72,00 & 33,90 & 18,90 & 26,40 \\
\hline 22 & 8,90 & 11,90 & 70,00 & 34,20 & 20,60 & 27,40 \\
\hline 23 & 1,00 & 0,30 & 85,00 & 27,90 & 19,70 & 23,80 \\
\hline 24 & 0,80 & 0,40 & 88,00 & 26,40 & 20,20 & 23,30 \\
\hline 25 & 5,40 & 0,80 & 86,00 & 29,20 & 17,70 & 23,45 \\
\hline 26 & 0,50 & 0,40 & 89,00 & 26,70 & 20,20 & 23,45 \\
\hline 27 & 7,10 & 0,00 & 77,00 & 27.20 & 16,40 & 21,80 \\
\hline 28 & 7,30 & 0,00 & 76,00 & 27,80 & 16,80 & 22,30 \\
\hline 29 & 11.40 & 0,00 & 74,00 & $\mathbf{3 1}, 00$ & 16,00 & 25,30 \\
\hline 30 & 10,60 & 0,00 & 69,00 & 32,80 & 16,90 & 24,85 \\
\hline 31 & 10,90 & 0.00 & 62,00 & 34,80 & 17,10 & 25,95 \\
\hline Média & 6,95 & 2,37 & 76.74 & 30.22 & 17,13 & 23,67 \\
\hline Total & 215,30 & 73.40 & 2379.00 & 936.70 & 530,90 & 733.80 \\
\hline
\end{tabular}


TABELA 23 - Registros metereológicos diários, do mês de novembro de 1993 em Piracicaba-SP

\begin{tabular}{|c|c|c|c|c|c|c|}
\hline Dia & $\begin{array}{l}\text { Insolaçào } \\
\text { h/d }\end{array}$ & $\begin{array}{l}\text { Precipitação } \\
\text { mm/alt. }\end{array}$ & $\begin{array}{l}\text { Umidade } \\
\text { relativa } \\
\%\end{array}$ & $\begin{array}{l}\text { Temp. máxima } \\
{ }^{0} \mathrm{C}\end{array}$ & $\begin{array}{l}\text { Temp. } \\
\text { minima } \\
{ }^{\circ} \mathrm{C}\end{array}$ & $\begin{array}{l}\text { Temp. } \\
\text { média } \\
{ }^{\circ} \mathrm{C}\end{array}$ \\
\hline 1 & 9,80 & 6,90 & 74,00 & 35,80 & 19,70 & 27,75 \\
\hline 2 & 2.10 & 0,00 & 84,00 & 27,90 & 20.40 & 24,15 \\
\hline 3 & 11,40 & 0,00 & 70,00 & 30,80 & 17,10 & 23,95 \\
\hline 4 & 11,30 & 0,00 & 72,00 & 32.20 & 13,40 & 22,80 \\
\hline 5 & 9,10 & 12,00 & 62,00 & 33,60 & 16,90 & 25,25 \\
\hline 6 & 3,00 & 8,10 & 78,00 & 32,60 & 18,90 & 25,75 \\
\hline 7 & 0,60 & 0,00 & 95,00 & 24,60 & 19,20 & 21,90 \\
\hline 8 & 3,50 & 0,00 & 84,00 & 28,20 & 19,30 & 23.75 \\
\hline 9 & 11,00 & 0,00 & 80,00 & 31,80 & 16,30 & 24,05 \\
\hline 10 & 10,50 & 0,00 & 76,00 & 31,40 & 16,90 & 24,15 \\
\hline 11 & 9,30 & 0,00 & 73,00 & 32,10 & 17,00 & 24,55 \\
\hline 12 & 11,50 & 0,00 & 64,00 & 33,40 & 12,60 & 23,00 \\
\hline 13 & 10,30 & 0,00 & 61,00 & 33,90 & 18,40 & 26,15 \\
\hline 14 & 10,00 & 0,00 & 60,00 & 34,10 & 19,00 & 26,55 \\
\hline 15 & 9,90 & 0,00 & 62,00 & 35,40 & 18,90 & 27,15 \\
\hline 16 & 8,40 & 1,80 & 62,00 & 36,10 & 19,80 & 27,95 \\
\hline 17 & 6,30 & 2,20 & 77,00 & 34,50 & 22,60 & 28.55 \\
\hline 18 & 5,70 & 1,20 & 89,00 & 29,80 & 20,90 & 25,35 \\
\hline 19 & 7,70 & 0,00 & 81,00 & 31,30 & 21,00 & 26,15 \\
\hline 20 & 12,00 & 0,00 & 69,00 & 32,70 & 19,10 & 25,90 \\
\hline 21 & 11,50 & 0,00 & 75,00 & 33,00 & 15,90 & 24,45 \\
\hline 22 & 7,70 & 25,00 & 80,00 & 33,90 & 16,50 & 25,20 \\
\hline 23 & 10,00 & 2.50 & 76,00 & 33,50 & 17,80 & 25,65 \\
\hline 24 & 6,90 & 3,50 & 77,00 & 33,60 & 19,70 & 26,65 \\
\hline 25 & 3,20 & 3,30 & 81,00 & 30,80 & 19,80 & 25,30 \\
\hline 26 & 7,10 & 25,10 & 87,00 & 30,70 & 20,40 & 25,55 \\
\hline 27 & 8,90 & 0,00 & 79,00 & 30,30 & 20,20 & 25,25 \\
\hline 28 & 12,10 & 0,00 & 63,00 & 30,40 & 18,80 & 24.60 \\
\hline 29 & 12,40 & 0.00 & 62,00 & 32,20 & 17,00 & 24,60 \\
\hline 30 & 11,90 & 0.40 & 63,00 & 35,60 & 15,00 & 25,30 \\
\hline Média & 8,51 & 3,05 & 73,87 & 32,21 & 18,28 & 25,25 \\
\hline Total & 255,40 & 91,60 & 2216,00 & 966,20 & 548,50 & 757,35 \\
\hline
\end{tabular}


TABELA 24 - Registros metereológicos diários. do mès de dezembro de 1993 em Piracicaba-SP

\begin{tabular}{|c|c|c|c|c|c|c|}
\hline Dia & $\begin{array}{l}\text { Insolação } \\
\mathrm{h} / \mathrm{d}\end{array}$ & $\begin{array}{l}\text { Precipitação } \\
\text { mm/alt. }\end{array}$ & $\begin{array}{l}\text { Umidade } \\
\text { relativa } \\
\%\end{array}$ & $\begin{array}{l}\text { Temp máxima } \\
{ }^{\circ} \mathrm{C}\end{array}$ & $\begin{array}{l}\text { Temp. } \\
\text { mínima } \\
{ }^{\circ} \mathrm{C}\end{array}$ & $\begin{array}{l}\text { Temp. } \\
\text { média } \\
{ }^{\circ} \mathrm{C}\end{array}$ \\
\hline 1 & 8,80 & 0,50 & 71,00 & 33,30 & 21,40 & 27,35 \\
\hline 2 & 9,10 & 6,80 & 80,00 & 34,40 & 20,60 & 27,50 \\
\hline 3 & 8,90 & 9,50 & 79,00 & 35,00 & 21,00 & 28,00 \\
\hline 4 & 12,00 & 9,30 & 78,00 & 34,40 & 19,70 & 27,05 \\
\hline 5 & 4,30 & 0,00 & 80,00 & 30,50 & 20,40 & 25,45 \\
\hline 6 & 6,10 & 0,00 & 77,00 & 33,80 & 20,80 & 27,30 \\
\hline 7 & 8,50 & 0,00 & 76,00 & 33,90 & 20,10 & 27,00 \\
\hline 8 & 7.20 & 4,80 & 83,00 & 34,20 & 22,20 & 28,20 \\
\hline 9 & 6,10 & 0,00 & 78,00 & 33,20 & 20,50 & 26,85 \\
\hline 10 & 1,50 & 20,00 & 91,00 & 27.40 & 21,70 & 24,55 \\
\hline 11 & 0,30 & 0,30 & 87,00 & 27,00 & 20,00 & 25,30 \\
\hline 12 & 11,70 & 0,00 & 77,00 & 31,40 & 17,30 & 24,35 \\
\hline 13 & 11,70 & 0,00 & 74,00 & 33,40 & 18,40 & 25,90 \\
\hline 14 & 10,50 & 0,00 & 73,00 & 34,70 & 19,70 & 27,20 \\
\hline 15 & 7,20 & 4,60 & 81,00 & 33,10 & 21,80 & 27,45 \\
\hline 16 & 5,50 & 8,30 & 87,00 & 31,60 & 21,80 & 26.70 \\
\hline 17 & 0,00 & 8,10 & 91,00 & 22,50 & 22,10 & 22,30 \\
\hline 18 & 4,40 & 0,00 & 82,00 & 27,90 & 17,80 & 22,85 \\
\hline 19 & 2.70 & 12,90 & 92.00 & 29.70 & 17,30 & 23,50 \\
\hline 20 & 2,00 & 0,80 & 92,00 & 29,70 & 20,20 & 24,95 \\
\hline 21 & 10,90 & 0,00 & 74,00 & 26,30 & 18,70 & 22,50 \\
\hline 22 & 8,40 & 0,00 & 75,00 & 29,00 & 15,40 & 22,20 \\
\hline 23 & 6,80 & 3,10 & 80,00 & 29,80 & 15,70 & 22,75 \\
\hline 24 & 0,00 & 0,00 & 89,00 & 24,40 & 18,20 & 21,30 \\
\hline 25 & 0,00 & 15.60 & 97,00 & 23,90 & 18,30 & 21,10 \\
\hline 26 & 4,10 & 0,70 & 86,00 & 29,50 & 17,50 & 23,50 \\
\hline 27 & 9,20 & 0,30 & 80,00 & 31,70 & 20,00 & 25,85 \\
\hline 28 & 2,30 & 28,90 & 90,00 & 27,90 & 20,10 & 24,00 \\
\hline 29 & 1,90 & 3,80 & 90,00 & 28,70 & 18,70 & 23,70 \\
\hline 30 & 0,60 & 8,10 & 92,00 & 22,70 & 20,70 & 21,70 \\
\hline 31 & 11,40 & 0,00 & 79,00 & 30,40 & 15,10 & 22,75 \\
\hline Média & 5,94 & 4,72 & 82,61 & 30,17 & 19,46 & 24,82 \\
\hline Total & 184,10 & 146,40 & 2561,00 & 935,40 & 603,20 & 769,30 \\
\hline
\end{tabular}


TABELA 25 - Registros metereológicos diários, do mês de janeiro de 1994 em Piracicaba-SP

\begin{tabular}{|c|c|c|c|c|c|c|}
\hline Dia & $\begin{array}{l}\text { Insolação } \\
\mathrm{h} / \mathrm{d}\end{array}$ & $\begin{array}{l}\text { Precipitação } \\
\text { mm/alt. }\end{array}$ & $\begin{array}{l}\text { Umidade } \\
\text { relativa } \\
\%\end{array}$ & $\begin{array}{l}\text { Temp máxima } \\
{ }^{\circ} \mathrm{C}\end{array}$ & $\begin{array}{l}\text { Temp. } \\
\text { minima } \\
{ }_{\mathrm{C}}\end{array}$ & $\begin{array}{l}\text { Temp. } \\
\text { média } \\
{ }^{\circ} \mathrm{C}\end{array}$ \\
\hline 1 & 3,40 & 0,00 & 91,00 & 29,30 & 16,60 & 22,95 \\
\hline 2 & 10,50 & 0,00 & 73,00 & 32,00 & 18,90 & 25,45 \\
\hline 3 & 0,20 & 2,90 & 88,00 & 27,40 & 18,30 & 22,55 \\
\hline 4 & 6,80 & 0,00 & 79,00 & 28,40 & 19.40 & 23,40 \\
\hline 5 & 3,80 & 0,00 & 80,00 & 27,00 & 17,70 & 22,35 \\
\hline 6 & 7,50 & 0,00 & 81,00 & 30,60 & 17,20 & 23,90 \\
\hline 7 & 8,10 & 23,10 & 93,00 & 31,00 & 18,40 & 24,70 \\
\hline 8 & 5,30 & 25,90 & 91.00 & 30,60 & 19.40 & 25,00 \\
\hline 9 & 1,20 & 0,00 & 94,00 & 28,00 & 19,80 & 23,90 \\
\hline 10 & 11,80 & 0,00 & 73,00 & 29,30 & 16,70 & 22,50 \\
\hline 11 & 10,30 & 0,00 & 72,00 & 31,30 & 14,90 & 23,10 \\
\hline 12 & 3,60 & 0,00 & 83,00 & 25,00 & 18,00 & 23,50 \\
\hline 13 & 1,30 & 1,50 & 91,00 & 28,20 & 19,40 & 23,20 \\
\hline 14 & 4,60 & 0,00 & 82,00 & 29,40 & 18,00 & 23,70 \\
\hline 15 & 5,40 & 0,00 & 81,00 & 29,60 & 18,20 & 23,90 \\
\hline 16 & 10,90 & 0,00 & 76,00 & 30,60 & 18,40 & 24,50 \\
\hline 17 & 9,20 & 0,00 & 78,00 & 33,10 & 19,40 & 26,25 \\
\hline 18 & 9,90 & 4,00 & 77,00 & 34,10 & 19,70 & 26,90 \\
\hline 19 & 5,00 & 0,30 & 84,00 & 31,80 & 20,60 & 26.20 \\
\hline 20 & 0,80 & 0,00 & 92,00 & 30,20 & 20,90 & 25,55 \\
\hline 21 & 8,70 & 0,00 & 84,00 & 31,10 & 21,00 & 26,05 \\
\hline 22 & 7,20 & 2,30 & 87,00 & 32,00 & 21,50 & 26,75 \\
\hline 23 & 4,40 & 0,00 & 88,00 & 32,30 & 20,40 & 26,35 \\
\hline 24 & 4,90 & 2,00 & 29,00 & 31,00 & 21,00 & 26,00 \\
\hline 25 & 4,00 & 6,40 & 92,00 & 29,40 & 21,00 & 25,20 \\
\hline 26 & 4,00 & 11,90 & 90,00 & 30,60 & 21,70 & 26,15 \\
\hline 27 & 0,30 & 42,50 & 95,00 & 28,20 & 20,10 & 24,65 \\
\hline 28 & 0,20 & 7,50 & 96,00 & 27,90 & 20,90 & 24,35 \\
\hline 29 & 5,10 & 0,00 & 85,00 & 32,20 & 19,60 & 25,90 \\
\hline 30 & 3,60 & 0.00 & 79,00 & 32,20 & 19,70 & 25,95 \\
\hline 31 & 7,60 & 1,60 & 82,00 & 32.20 & 20.40 & 26,30 \\
\hline Média & 3,63 & 4.35 & 83,71 & 30,29 & 19.26 & 24,78 \\
\hline Total & 174,60 & 134.50 & 2295,00 & 939,90 & 597,20 & 768,05 \\
\hline
\end{tabular}


TABELA 26 - Registros metereológicos diários, do mês de fevereiro de 1994 em Piracicaba-SP

\begin{tabular}{|c|c|c|c|c|c|c|}
\hline Dia & $\begin{array}{l}\text { Insolação } \\
\mathrm{h} / \mathrm{d}\end{array}$ & $\begin{array}{l}\text { Precipitação } \\
\mathrm{mm} / \mathbf{a l t} \text {. }\end{array}$ & $\begin{array}{l}\text { Umidade } \\
\text { relativa } \\
\%\end{array}$ & $\begin{array}{l}\text { Temp máxima } \\
{ }^{\circ} \mathrm{C}\end{array}$ & $\begin{array}{l}\text { Temp. } \\
\text { mínima } \\
{ }^{\circ} \mathrm{C}\end{array}$ & $\begin{array}{l}\text { Temp. } \\
\text { média } \\
{ }^{\circ} \mathrm{C}\end{array}$ \\
\hline 1 & 7,70 & 0,00 & 73,00 & 33,40 & 19,90 & 26,65 \\
\hline 2 & 7,70 & 0,00 & 76,00 & 35,10 & 20,90 & 23,00 \\
\hline 3 & 10,30 & 0,00 & 72,00 & 35,80 & 21,30 & 28,55 \\
\hline 4 & 7,90 & 0,00 & 73,00 & 35,00 & 20,40 & 27,70 \\
\hline 5 & 8,70 & 0,00 & 84,00 & 36,00 & 21,00 & 29,50 \\
\hline 6 & 3,40 & 39,30 & 87,00 & 29,00 & 20,00 & 24,50 \\
\hline 7 & 8,00 & 18,00 & 91,00 & 31,50 & 20,00 & 25,75 \\
\hline 8 & 6,60 & 0,00 & 86,00 & 31,00 & 19,40 & 25,20 \\
\hline 9 & 9,90 & 9,50 & 82,00 & 33,30 & 17,20 & 25,25 \\
\hline 10 & 7,90 & 0,00 & 82,00 & 33,00 & 20,10 & 26,55 \\
\hline 11 & 7,90 & 0,00 & 83,00 & 33,00 & 20,00 & 26,50 \\
\hline 12 & 8,80 & 3,30 & 85,00 & 33,00 & 21,00 & 27,00 \\
\hline 13 & 5,40 & 15,80 & 86,00 & 31,30 & 19,10 & 25,20 \\
\hline 14 & 7,60 & 0,00 & 87,00 & 32,00 & 21,00 & 26,50 \\
\hline 15 & 5,90 & 0,30 & 88,00 & 33,50 & 20,00 & 26,75 \\
\hline 16 & 10,60 & 0,30 & 85,00 & 34,00 & 21,00 & 27,50 \\
\hline 17 & 11,20 & 0,00 & 81,00 & 34,20 & 20,40 & 27,00 \\
\hline 18 & 6,00 & 0,00 & 82,00 & 33,20 & 20,00 & 26,60 \\
\hline 19 & 8.30 & 12,30 & 78,00 & 35,50 & 20,00 & 27.75 \\
\hline 20 & 6,90 & 32,60 & 81,00 & 34,00 & 21,10 & 27,55 \\
\hline 21 & 10,00 & 0,00 & 80,00 & $\mathbf{3 4 , 0 0}$ & 19,20 & 26,60 \\
\hline 22 & 10,10 & 8,30 & 73,00 & 33,20 & 20,00 & 26,70 \\
\hline 23 & 8,80 & 0,00 & 92,00 & 31,00 & 20,00 & 25,50 \\
\hline 24 & 8,20 & 0,00 & 80,00 & 33,60 & 20,00 & 21,60 \\
\hline 25 & 2,40 & 0,00 & 88,00 & 33,00 & 20,40 & 26,70 \\
\hline 26 & 3,40 & 1,10 & 90,00 & 31,00 & 20,20 & 25,60 \\
\hline 27 & 7,90 & 5,70 & 84,00 & 30,40 & 20,00 & 25,20 \\
\hline 28 & 5,90 & 7,90 & 87,00 & 30,80 & 21,40 & 26,10 \\
\hline Média & 7,63 & 5,51 & 82,71 & 32,97 & 20,19 & 26,53 \\
\hline Total & 213,50 & 154,40 & 2316,00 & 923,20 & 565,40 & 744,30 \\
\hline
\end{tabular}


TABELA 27 - Registros metereológicos diários, do mês de março de 1994 em Piracicaba-SP

\begin{tabular}{|c|c|c|c|c|c|c|}
\hline Dia & $\begin{array}{l}\text { Insolação } \\
\mathrm{h} / \mathrm{d}\end{array}$ & $\begin{array}{l}\text { Precipitação } \\
\text { mm/alt. }\end{array}$ & $\begin{array}{l}\text { Umidade } \\
\text { relativa } \\
\%\end{array}$ & $\begin{array}{l}\text { Temp. } \\
\text { máxima } \\
{ }^{\circ} \mathrm{C}\end{array}$ & $\begin{array}{l}\text { Temp. } \\
\text { mínima } \\
{ }^{\circ} \mathrm{C}\end{array}$ & $\begin{array}{l}\text { Temp. } \\
\text { média } \\
{ }^{\circ} \mathrm{C}\end{array}$ \\
\hline 1 & 1,50 & 32,80 & 93,00 & 28,40 & 21,20 & 24,80 \\
\hline 2 & 1,30 & 0,50 & 86,00 & 27,30 & 20,90 & 24,10 \\
\hline 3 & 6,10 & 0,00 & 81,00 & 27,00 & 18,40 & 22,70 \\
\hline 4 & 10,90 & 0,00 & 79,00 & 28,40 & 14,20 & 21,30 \\
\hline 5 & 5,50 & 0,00 & 77,00 & 28,30 & 17.20 & 22,75 \\
\hline 6 & 10,90 & 0,00 & 78,00 & 26,80 & 18,30 & 22,55 \\
\hline 7 & 5,00 & 1,40 & 87,00 & 27,40 & 17,40 & 22,40 \\
\hline 8 & 8,00 & 0,00 & 86,00 & 30.60 & 17,50 & 24,05 \\
\hline 9 & 7,70 & 0,00 & 85,00 & 31,00 & 18.00 & 24,50 \\
\hline 10 & 6,60 & 0,00 & 86,00 & 31,00 & 20,00 & 25,50 \\
\hline 11 & 3,80 & 45,10 & 89,00 & 29,40 & 19,90 & 24,65 \\
\hline 12 & 6,50 & 0,00 & 87,00 & 30,80 & 18,20 & 24,50 \\
\hline 13 & 9,00 & 0,00 & 81,00 & 31,70 & 18,20 & 24,95 \\
\hline 14 & 9,40 & 0,00 & 82,00 & 31,20 & 17,30 & 24,25 \\
\hline 15 & 7,80 & 0,00 & 79,00 & 30,10 & 17,30 & 23,70 \\
\hline 16 & 10,50 & 0,00 & 79,00 & 31,60 & 18,40 & 25,00 \\
\hline 17 & 6,80 & 2,20 & 85,00 & 32,80 & 17,90 & 25,35 \\
\hline 18 & 8,30 & 0,00 & 81,00 & 32.10 & 20,00 & 26,05 \\
\hline 19 & 4,80 & 45,90 & 91,00 & 31,50 & 19,60 & 25,55 \\
\hline 20 & 2,00 & 13,90 & 94,00 & 27,00 & 20.00 & 25,30 \\
\hline 21 & 7,90 & 2,50 & 86,00 & 29,40 & 19,80 & 24,60 \\
\hline 22 & 8,20 & 0,00 & 85,00 & 29,60 & 20,00 & 24,80 \\
\hline 23 & 8,50 & 0,00 & 80,00 & 30,00 & 18,20 & 24,10 \\
\hline 24 & 2,90 & 0,70 & 88,00 & 29,00 & 18,40 & 23,70 \\
\hline 25 & 4,30 & 38,70 & 91,00 & 30,40 & 20,00 & 25,20 \\
\hline 26 & 4,80 & 2,00 & 90,00 & 28.50 & 19,90 & 24,20 \\
\hline 27 & 4,40 & 0,00 & 82,00 & 26,30 & 18,60 & 22,45 \\
\hline 28 & 9,90 & 0,00 & 79,00 & 30,30 & 15,50 & 22,90 \\
\hline 29 & 10,30 & 0,00 & 81,00 & 31,40 & 16,40 & 23,90 \\
\hline 30 & 9,60 & 0,00 & 79.00 & 31.40 & 17,30 & 24,45 \\
\hline 31 & 0,60 & 37,00 & 89,00 & 28,90 & 19,60 & 24,25 \\
\hline Média & 6,57 & 7,18 & 84,39 & 29,66 & 18,50 & 24,08 \\
\hline Total & 203,80 & 222.70 & 2616,00 & 919,60 & 573,60 & 746,60 \\
\hline
\end{tabular}


TABELA 28 - Registros metereológicos diários, do mês de abril de 1994 em Piracicaba-SP

\begin{tabular}{|c|c|c|c|c|c|c|}
\hline Dia & $\begin{array}{l}\text { Insolaçăo } \\
\text { h/d }\end{array}$ & $\begin{array}{l}\text { Precipitação } \\
\mathrm{mm} / \text { alt. }\end{array}$ & $\begin{array}{l}\text { Umidade } \\
\text { relativa } \\
\%\end{array}$ & $\begin{array}{l}\text { Temp. } \\
\text { máxima } \\
{ }^{\circ} \mathrm{C}\end{array}$ & $\begin{array}{l}\text { Temp. } \\
\text { mínima } \\
{ }^{\circ} \mathrm{C}\end{array}$ & $\begin{array}{l}\text { Temp. } \\
\text { média } \\
{ }^{\circ} \mathrm{C}\end{array}$ \\
\hline I & 2.20 & 0,40 & 88,00 & 27,40 & 20,70 & 24,05 \\
\hline 2 & 7,50 & 0,00 & 83,00 & 26,40 & 16,60 & 21,50 \\
\hline 3 & 10,50 & 0,00 & 79,00 & 29,30 & 14,60 & 21,95 \\
\hline 4 & 10,10 & 0,00 & 81,00 & 29,40 & 13,40 & 21,40 \\
\hline 5 & 9,30 & 0,00 & 77,00 & 31,30 & 14,20 & 22,75 \\
\hline 6 & 9,30 & 2,20 & 76,00 & 31,60 & 15,40 & 23,50 \\
\hline 7 & 4,90 & 0,00 & 85,00 & 25,40 & 19,10 & 22,25 \\
\hline 8 & 8,60 & 0,00 & 83,00 & 25,00 & 12,20 & 18,60 \\
\hline 9 & 9,20 & 0,00 & 90,00 & 28,40 & 13,60 & 21,00 \\
\hline 10 & 9,40 & 0,00 & 80,00 & 30,20 & 13,70 & 21,95 \\
\hline 11 & 9,60 & 0,00 & 79,00 & 30,60 & 14,80 & 22,70 \\
\hline 12 & 9,40 & 0,00 & 79,00 & 30,60 & 16,60 & 23,60 \\
\hline 13 & 7,00 & 2,80 & 81,00 & 30,30 & 17,30 & 23,80 \\
\hline 14 & 2,90 & 0,70 & 92,00 & 26,70 & 17,70 & 22,20 \\
\hline 15 & 8,30 & 0,00 & 82,00 & 28,40 & 17,40 & 22,90 \\
\hline 16 & 8,60 & 0,00 & 83,00 & 29,60 & 14,40 & 22,00 \\
\hline 17 & 6,40 & 0,00 & 80,00 & 30,60 & 15,70 & 23,15 \\
\hline 18 & 0,00 & 2,10 & 96,00 & 23,40 & 20,00 & 21,70 \\
\hline 19 & 4,20 & 0.00 & 83.00 & 26,20 & 18,30 & 22,25 \\
\hline 20 & 7,50 & 0,00 & 74,00 & 29.30 & 15,10 & 22,20 \\
\hline 21 & 7,80 & 49,40 & 76,00 & 32,40 & 17,90 & 25,15 \\
\hline 22 & 2,00 & 32,00 & 89,00 & 27,80 & 19,40 & 23,60 \\
\hline 23 & 5,80 & 0,00 & 83,00 & 28,50 & 17,60 & 23,05 \\
\hline 24 & 7,70 & 0,80 & 80,00 & 29,00 & 17,40 & 23,20 \\
\hline 25 & 8,50 & 0,00 & 80,00 & 30,40 & 17,70 & 24,05 \\
\hline 26 & 5,30 & 24,50 & 82,00 & 29,30 & 18,60 & 23,95 \\
\hline 27 & 8,00 & 0,00 & 79,00 & 31,40 & 17,90 & 24,65 \\
\hline 28 & 10,10 & 0,00 & 74,00 & 31,70 & 17,60 & 24,65 \\
\hline 29 & 9,80 & 0,00 & 75,00 & 29,70 & 17,80 & 23,75 \\
\hline 30 & 10,10 & 0.00 & 75,00 & 29,10 & 16,10 & 22,60 \\
\hline Média & 7,33 & 3,83 & 81,10 & 28,98 & 16,63 & 22,80 \\
\hline Total & 220,00 & 114,90 & 2433,00 & 869,40 & 498,80 & 684,10 \\
\hline
\end{tabular}

